\title{
AVALIAÇĀO DE SOROGRUPOS DE RIZÓBIOS ISOLADOS DE SOJA EM DOIS SISTEMAS DE CULTIVO SOB LATOSSOLO ROXO
}

\author{
PATRICIA AUGUSTO DE OLIVEIRA \\ Bióloga
}

Orientador: Dr. ELI SIDNEY LOPES

\begin{abstract}
Dissertação apresentada à Escola Superior de Agricultura "Luiz de Queiroz", da Universidade de São Paulo, para obtenção do tífulo de Mestre em Agronomia Área de Concentraçå: Microbiologia Agricola.
\end{abstract}

PIRACICABA

Estado de Såo Paulo - Brasil

Fevereiro - 1996 


\section{Oliveira, Patricla Augusto de}

Avaliação de sorogrupos de rizóbios isolados de soja em dois sistemas de cultivo sob latossolo roxo / Patricia Augusto de Oliveira. - - Piracicaba, 1996.

85p. : il.

Disșertaçāo (mestrado) - - Escola Superior de Agricultura Luiz de Queiroz, 1996.

Bibliografia.

1. Bactéria fixadora de nitrogênio - Isolamento 2. Latossolo roxo 3. Nitrogênio em soja - Fixação biológica 4. Soja - Nodulação l. Título

$$
\text { CDD } \quad 633.34
$$




\title{
AVALIAÇÃO DE SOROGRUPOS DE RIZÓBIOS ISOLADOS DE SOJA EM DOIS SISTEMAS DE CULTIVO SOB LATOSSOLO ROXO
}

\author{
PATRÍCIA AUGUSTO DE OLIVEIRA
}

APROVADA EM 08/03/96

COMISSÃO JULGADORA:

Dr. Eli Sidney Lopes

$\mathrm{Dr}^{\mathrm{a}}$ Maria Luiza C. de Oliveira Lombardi

Prof $^{\mathrm{a}} \mathrm{Dr}^{\mathrm{a}}$ Eliana G. M. Lemos
IAC / Campinas

IAC / Campinas

UNESP / Jaboticabal

Tisegh

Dr. Eli Sidney Lopes

- Orientador - 
"O mais importante e bonito do mundo é isto: que as pessoas não estão sempre iguais, ainda não foram terminadas - mas que elas vão sempre mudando.

Afinam e desafinam". 
A minha mãe, Maria Ilda ,referencial de força e alegria,

e aos meus irmãos,

dedico.

Ao meu pai, João Bertoldo, referencial

de um pesquisador apaixonado,

ofereço. 


\section{AGRADECIMENTOS}

Agradeço a todas as pessoas que de alguma forma contribuiram para a realização deste trabalho especialmente:

Ao meu orientador Dr. Eli Sidney Lopes pela transferência de conhecimentos técnicos, experiências de vida, orientação e amizade.

À toda a Seção de Microbiologia do Solo do Instituto Agronômico de Campinas, pelo apoio técnico e amizade, e em especial a Dra. Maria Luiza C. O. Lombardi, por ter me iniciado na ciência da rizobiologia, e a Maria Leonilde M. de Sousa (D. Léo) pelo cafezinho gostoso na hora certa.

À Seção de Fertilidade do Solo e Nutrição de Plantas do Instituto Agronômico de Campinas pelas análises de solos.

À Cooperativa dos Agricultores da Região de Orlândia (CAROL) pelo auxílio financeiro e em especial ao Eng. Agrônomo André Luis Pazzeto, pela colaboração e apoio na experimentação a campo.

Ao Departamento de Tecnologia da UNESP/ Jaboticabal, pelos soros fornecidos.

À ESALQ/USP, pela oportunidade de estudo.

À professora Dra Eliana G. M. Lemos, pela amizade, ajuda preciosa e pela oportunidade de realização de parte deste trabalho, no laboratório do Depto de Tecnologia da UNESP/Jaboticabal.

À Dra Lúcia M. C. Alves e ao João Carlos Campanharo, do Depto de Tecnologia da UNESP/Jaboticabal, pela amizade e apoio neste trabalho.

Ao Engr. Nilo Ykuta, do Centro de Biotecnologia/UFRGS, pela orientação do estágio, durante a realização deste trabalho. 
À FAPESP, pela bolsa concedida.

A querida amiga, Bióloga MSc., Silene Cristina de Lima, por toda ajuda neste trabalho, pela sua alegria, força e amizade durante os momentos dificeis e os inesqueciveis em que pudemos trabalhar, viajar e festejar juntas. A você, querida amiga, minha gratidão eterna.

Aos colegas da PG-ESALQ, Denise, Fernando, Amauri, Wagner, Gepeto e Tilli, cuja convivência marcante deixou inúmeras recordações gostosas, apesar de termos aprendido juntos que " rapadura é doce mas não é mole não !".

Ao Eng. Agr. MSc. Hélcio de Abreu Jr. pela amizade e ajuda providencial neste trabalho.

Aos Drs. João Bertoldo de Oliveira e José Antônio Jorge, pela "força" no summary.

À minha família querida, meus pais, irmãos, cunhada, tios, avós, e primos, pelos momentos de alegria e descontração, tão importantes para quem precisa continuar na "luta".

À Egberto Gustavo do Carmo, querido Gui, pela inestimável ajuda, por ser paciente, me compreender e amar.

E finalmente, mas não em último lugar, a Deus, pelo amor e proteção incondicional. 


\section{SUMÁRIO}

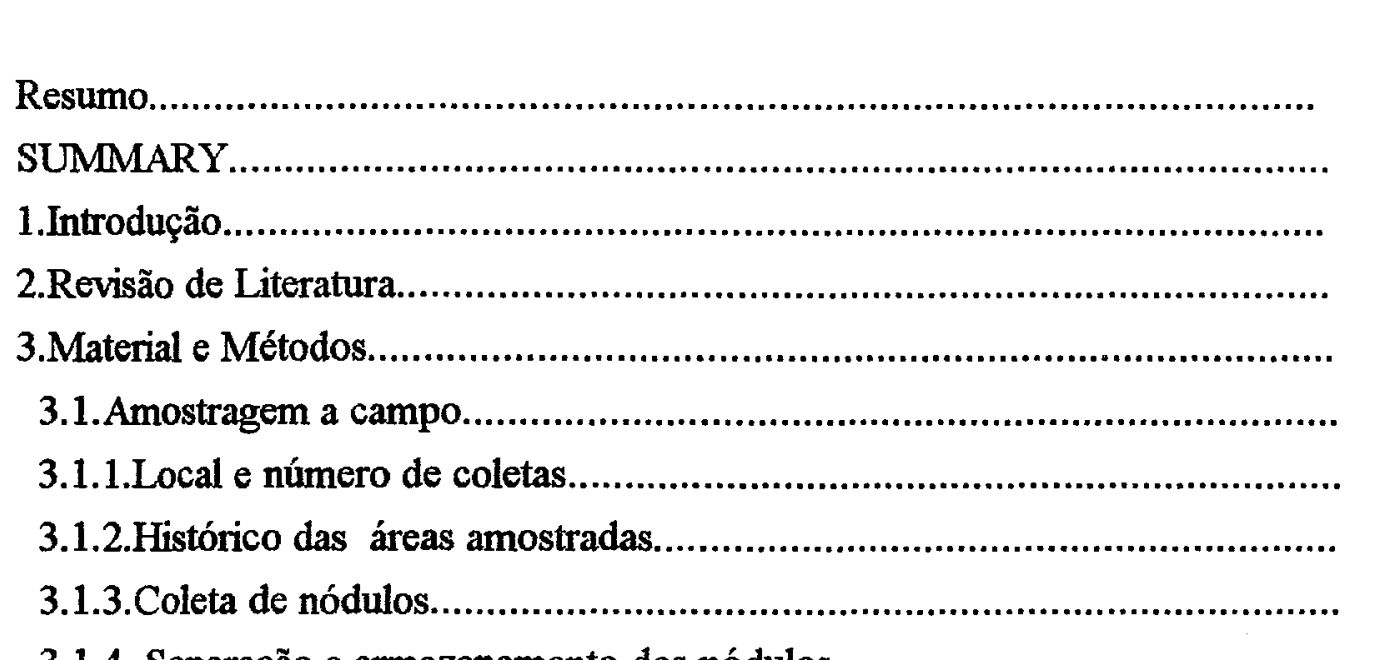

Página

viii

$\mathrm{xi}$

01

04

13

13

13

15

15

3.1.4. Separação e armazenamento dos nódulos............................................... 15

3.1.5.Caracterização e amostragem do solo.................................................... 16

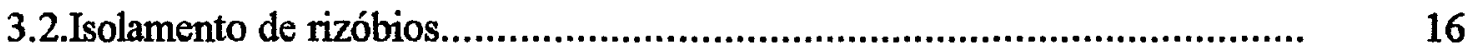

3.2.1.Teste preliminar de eficiência e nodulação............................................... 17

3.3.Caracterização dos bacteróides e culturas puras........................................... 18

3.3.1.Teste de aglutinação e eletroforese (caracterização das culturas puras)...... 18

3.3.1.1.Preparo das amostras...................................................................... 19

3.3.1.2. Preparo de gel de poliacrilamida......................................................... 20

3.3.1.3. Deteç̧ão por nitrato de prata.......................................................... 20

3.3.2.Teste de "immunodot" (caracterização das suspensões nos nódulos)........... 21

4.Resultado e Discussão.............................................................................. 24

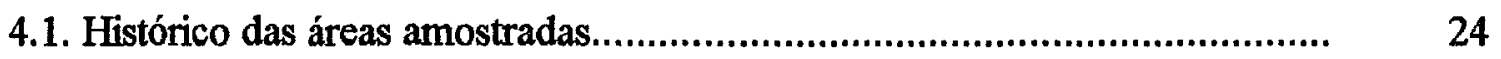

4.2. Isolamento de rizóbios.................................................................... 30

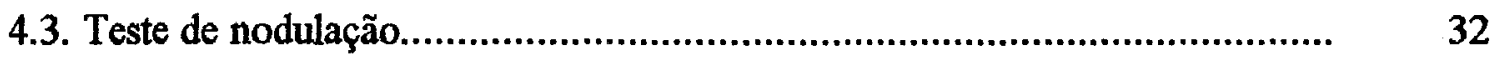

4.4. Caracterização das culturas puras.............................................................

4.4.1. Teste de aglutinação com soros hiperimunes anti-células inteiras.............. 34

4.4.2. Teste de aglutinação com soros hiperimunes anti-lipopolissacarideos....... 34 .

4.4.3. Eletroforese de LPS em SDS-PAGE................................................. $\quad 35$

4.5. Teste preliminar de eficiência...................................................................

4. 6. Caracterização das estirpes nos nódulos..................................................... 50

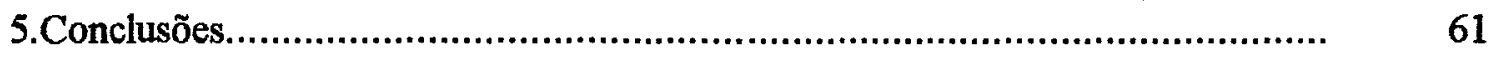

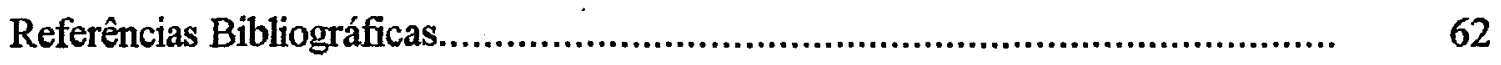

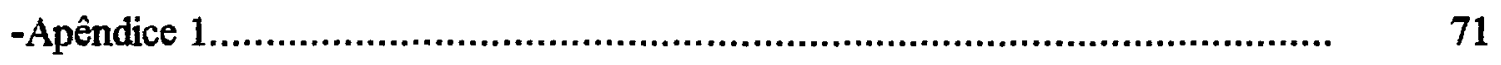




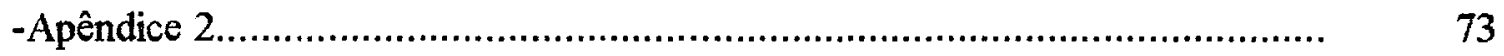

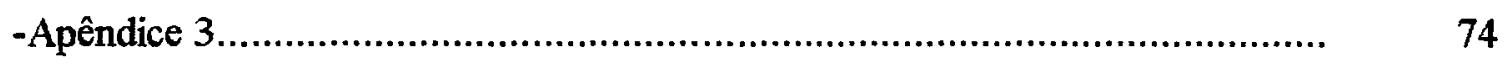

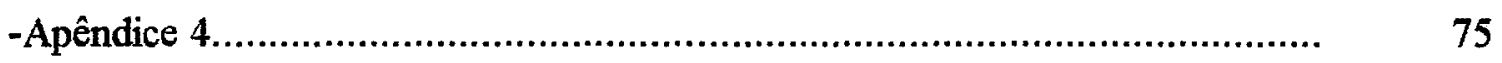

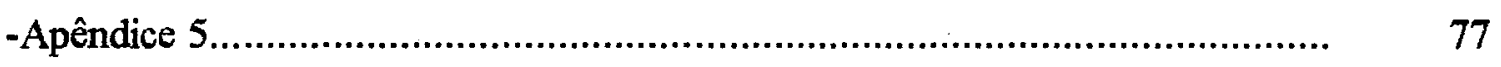

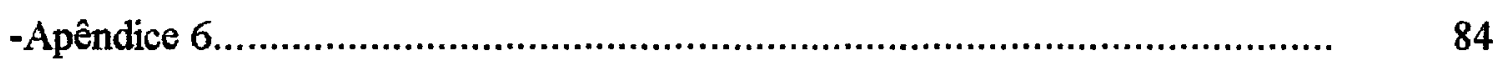




\title{
CARACTERIZAÇÃO DE SOROGRUPOS DE RIZÓBIOS ISOLADOS DE SOJA EM DOIS SISTEMAS DE CULTIVO SOB LATOSSOLO ROXO
}

\author{
Autora: Patrícia Augusto de Oliveira \\ Orientador: Dr. Eli Sidney Lopes
}

\section{RESUMO}

Foi feita uma avaliação de predominância de ocorrência e uma avaliação preliminar da eficiência de fixação de $\mathrm{N}_{2}$ de estirpes de rizóbios isoladas de soja IAS-5, cultivada em Latossolo Roxo, em cinco municípios da região de Orlândia. Foram coletadas amostras em 10 propriedades, compostas de 20 sub amostras cada, numa profundidade de 0-20 cm, com soja sob rotação com cana-de-açúcar (Saccharum officinarum L.) e 10 sob rotação com milho (Zea mays L.) de safrinha.

Foram também efetuadas coletas de informações sobre o histórico de uso das áreas e sobre as lavouras de soja amostradas. Apesar da boa nodulação encontrada, $36 \%$ dos agricultores informaram usar formulações de fertilizantes nitrogenados e que a dose adicionada é pequena $(5,8$ a $13 \mathrm{Kg} / \mathrm{ha})$, mesmo quando inoculam. A maioria $(67 \%)$ dos agricultores não acredita em benefícios da inoculação, sendo que $93 \%$ conserva o inoculante fora da geladeira, e $75 \%$ já havia inoculado as sementes em outros anos. Todos os agricultores, informaram adubar com $\mathrm{P}$ e $\mathrm{K}$, usando $56 \mathrm{Kg}$ de $\mathrm{P}_{2} \mathrm{O}_{5}$ e $49 \mathrm{Kg}$ de $\mathrm{K}_{2} \mathrm{O} / \mathrm{ha}$ em média, em área de rotação soja/milho; e de $62 \mathrm{~kg}$ de $\mathrm{P}_{2} \mathrm{O}_{5}$ e $66 \mathrm{Kg}$ de $\mathrm{K}_{2} \mathrm{O} / \mathrm{ha}$, em área de rotação soja/cana, respectivamente.

De cada propriedade foram separados 40 nódulos intactos para caracterização de estirpes por "immunodot" em suspensões dos bacteróides dos nódulos (totalizando 800 nódulos, para as 20 propriedades), e isoladas 91 estirpes de nódulos coletados nas mesmas áreas amostradas. As estirpes isoladas foram incorporadas a Coleção de Rhizobium e Bradyrhizobium spp do Instituto Agronômico de Campinas.

Para a caracterização das estirpes foram utilizados antissoros das estirpes SEMIA $5052,5025,587,5019,5080,566,5032,5061$ e 518, correspondentes aos sorogrupos I, II, III, IV, V, VI, VII, VIII e IX, respectivamente conforme designação 
IPAGRO/MIRCEN, 1991. Apenas vinte e uma estirpes das 91 culturas puras foram identificadas por aglutinação utilizando-se antissoros de células inteiras (de oito dos sorogrupos citados), sendo duas do sorogrupo IV, onze do VI e oito do IX. Das setenta restantes, 41 apresentaram reações cruzadas e foram submetidas a novo teste de aglutinação com antissoro preparado com lipopolissacarídeos extraídos de estirpes dos sorogrupos I, II,III,IV e VIII; isso possibilitou caracterizar mais 25 estirpes, pertencentes aos sorogrupos I (uma), III (quatro), IV (dezessete) e VIII (três).

As quarenta e cinco estirpes restantes foram caracterizadas por eletroforese de LPS em SDS-PAGE, como estirpes dos sorogrupos I (vinte e cinco), III (dez), IV (oito) e VIII (duas).

A ocupação dos 800 nódulos pelas estirpes naturalizadas, SEMIA 5052,587,5019 e 566 , definida pelo teste do "immunodot", foi de cerca de $20 \%, 15 \%, 22 \%$ e $5 \%$, respectivamente, para a área de rotação soja/milho. Portanto, $38 \%$ dos nódulos ficaram sem caracterização das estirpes. Para a rotação soja/cana a ocupação por essas estirpes, na mesma sequencia, foi de $24 \%, 3 \%, 4 \%$ e $2 \%$, ficando neste caso, cerca de $67 \%$ dos nódulos sem identificação das estirpes. A sobrevivência das estirpes recomendadas (SEMIA 587 e SEMIA 5019) ocorreu, portanto, mesmo na ausência da planta hospedeira por 4-6 anos, ainda que, aparentemente, em menor proporção que na rotação anual. A maior proporção de estirpes não identificadas na área da rotação com cana pode estar associada com a ausência da planta hospedeira, como também às mudanças na comunidade de rizóbios, determinadas pelas diferenças de manejo. Além disso, poderia se explicar por diferenças na ocorrência de Bradyrhizobium spp nativos, capazes de nodular soja.

As culturas puras de prováveis rizóbios foram submetidas a teste de nodulação para confirmação da identidade genérica. A comunidade de rizóbios do solo, composta por estirpes dos sorogrupos analisados, mostrou-se com capacidade varível de fixar nitrogênio. A maioria dos isolados apresentaram eficiência relativa inferior à da estirpe SEMIA 587, recomendada para a produção de inoculantes. Observou-se que a média de ER, $80 \%$, para os isolados de área em cultivo soja/milho, foi ligeiramente superior à dos isolados em área de cultivo soja/cana (71\%). Apenas $34 \%$ das estirpes isoladas em área de cultivo soja/milho (SMS- 790, 799, 800, 802, 805, 814, 816, 818, 819, 823, 830, 833, $834,836,839$ e 843 ), e $18 \%$ (SMS-863, 864, 865, 872, 882, 884, 885 e 919) em área 
soja/cana, mostraram-se eficientes, com valores de ER maior que $90 \%$ do da estirpe recomendada, SEMIA 587.

A análise do padrão eletroforético em SDS-PAGE do LPS da parede celular das estirpes mostrou ser um método importante para a caracterização biológica de várias estirpes de rizóbios, que de outra forma não seriam identificadas. 


\title{
SOYBEAN RHIZOBIA ISOLATED SOROGRUPS EVALUATION IN TWO CROP SYSTEMS IN DUSKY-RED LATOSOLS
}

\author{
Author: Patricia Augusto de Oliveira \\ Adviser: Dr. Eli Sidney Lopes
}

\section{SUMMARY}

An evaluation of the predominance of occurence and a preliminar evaluation of $\mathrm{N}_{2}$ fixation efficiency of rhizobia strains isolated from soybean IAS-5, cultivated in DuskyRed-Latosol (Oxisols) from five countries in Orlândia region, São Paulo State, Brazil, was carried out. Samples were collected in ten farms (20 sampling spots each) from soybean plots in rotation with sugar-cane (Saccharum officinarum, L.) and in ten farms having soybean in rotation with corn (Zea Mays, L.). In each plot four soil subsamples (0$20 \mathrm{~cm}$ ) were collected to run chemical analyses.

It was also collected informations about historical background on the management of each plot and of the soybean sampled crops. In spite of the good nodulation observed, $36 \%$ of the farmers informed to use nitrogen fertlizers formulations, that add small amounts of nitrogen $(5,8$ up to $13 \mathrm{Kg}$ of $\mathrm{N} / \mathrm{ha})$ even when inoculating. The majority (67\%) of the farmers do not believe in benefices from inoculation, $93 \%$ keep the inoculant out the refrigerator and $75 \%$ had inoculated the seeds in previous years. All the farmer informed to have used $\mathrm{P}$ and $\mathrm{K}$ fertilizers, adding an average of $56 \mathrm{~kg}$ of $\mathrm{P}_{2} \mathrm{O}_{5}$ /ha and $49 \mathrm{Kg}$ of $\mathrm{K}_{2} \mathrm{O} / \mathrm{ha}$ in soybeam/corn rotation and with $62 \mathrm{Kg}$ of $\mathrm{P}_{2} \mathrm{O}_{5} / \mathrm{ha}$ and $66 \mathrm{~kg}$ of $\mathrm{K}_{2} \mathrm{O} /$ ha in soybeam/sugar-cane rotation.

From each farm it was separated forty nodules for characterization of strains by "immunodot" technique in bacteroid nodule suspensions (total of 800 nodules to all farms) and isolated ninenty-one, probable rhyzobia from nodules collected in the same sampled plots. The isolated strains were incorporated in the Collection of Rhizobium and Bradyrhizobium spp of the Instituto Agronômico of Campinas.

For characterization it was used antiserum of strains SEMIA 5052, 5025, 587, $5019,5080,566,5032,5061$ and 518, related respectivelly with the I, II, III, IV, V, VI, 
VII, VIII and IX serogroups (accordingly to IPAGRO/MIRCEN definitions). Only twenty-one strains from the ninenty-one pure cultures were identified by agglutination, using hole cells antiserum (from eight of the mentioned serogroups), beeing two from the serogroup $\mathrm{V}$, eleven from the VI and eigth from the IX. From the seventy remainings, forty-one showed crossed reaction and were submitted to a new agglutination test with antiserum prepared with exolipolissacharids from the serogroups I, II, III,IV and VIII, making possible to characterize plus twenty-five strains, belonging to the serumgroups I (one), III (four), IV (seventeen) and VIII (three).

The remaining forty-five strains were characterized by eletrophoresis of LPS in SDS-PAGE, as strains from the serumgroups I (twenty-five), III (ten), IV (eight) and VIII (two).

The percentage of occupancy of the eigth hundred nodules by the naturalized strains, for the SEMIA 5052, 587, 5019 and 566 accomplished by the "immunodot" test, were about $20 \%, 15 \%, 22 \%$ and $5 \%$ respectivelly, for the soybean/com rotation areas. Therefore, $38 \%$ of nodules remained without characterization of their strains. For the soybean/sugar-cane rotation areas the occupation by these strains, in the same sequence were approximatelly $24 \%, 3 \%, 4 \%$ and $2 \%$, remaining in this case $67 \%$ of the nodules without strain identification. The survival of the recommended strains (SEMIA 578 and SEMIA 5019) took place, therefore, even in the absence of the host plant for 4-6 years, although apparentelly, in smaller proportion than in the annual rotation. The greater proportion of non identified strains in the sugar-cane rotation areas can be associated with the absence of the host plant, as well as with changes in the rhizobia community determined by differences in management. Besides that, it could be also explained by differences in the occurence of native Bradyrhizobium spp, which promotes soybean nodulation.

The ninety-one pure culture of rhizobia were submitted to a nodulation tests to confirm the generic identity. The soil rhizobia community, composed by strains of the serogroups above indicated showed a variable capacity to fix nitrogen. The majority of the isolates showed a smaller relative efficiency (ER) than the strain SEMIA 587, recommended for the production of inoculants. It was also observed that the $80 \%$ average of ER, for isolates from the soybean/corn rotation was slightly higher than the isolates from the soybean/sugar-cane (71\%) areas. Only $34 \%$ of the isolated strains in 
soybeam/corn areas (SMS-790, 799, 800, 802, 805, 814, 816, 818, 819, 823, 830, 833, $834,836,839$ and 843), and 18\% (SMS-863, 864, 865, 872, 882, 884, 885 and 919), in soybeam/sugar-cane areas showed to be efficient, with ER values higher than $90 \%$ of the recomended strain, SEMIA 587.

The analyse of the eletrophoretic pattern in SDS-PAGE of LPS of the cells walls of those strains, showed to be an important method for byological characterization of several rhizobia strains, which otherwise could not be identified. 


\section{INTRODUÇÃO}

A soja (Glycine max (L). Merril) é uma das leguminosas que mais se beneficia do processo de fixação simbiótica do Nitrogênio.

Estudos têm demonstrado que até $60 \%$ do Nitrogênio requerido na produção da soja pode ser obtido com a fixação do $\mathrm{N}_{2}$ atmosférico (STREETER, 1973, citado por VIDOR et al, 1983).

A cultura da soja, quando bem nodulada pode dispensar a aplicação de adubos nitrogenados, já que igual produtividade pode ser obtida em culturas adequadamente inoculadas e noduladas e naquelas adubadas com fertilizantes nitrogenados. Desta forma, o lucro alcançado pelo produtor, poderia ser calculado a partir da diferença entre o custo financeiro da adubação nitrogenada e o da inoculação.

Segundo os cálculos de LIMA (1995), a econômia com adubo nitrogenado para a área de soja cultivada no Estado de São Paulo, em 1992, foi no mínimo da ordem de 474 milhões de dólares, sem considerar que a eficiência do aproveitamento do nitrogênio do adubo nitrogenado não ultrapassa a $\mathbf{5 0 \%}$.

Técnicas que evitem o uso de adubos e que não exijam alto dispêndio de energia têm tido grande importância nas pesquisas científicas atuais, visando encontrar meios que possam gerar alimentos ricos em proteínas com o menor custo possível. Consequentemente, a fixação biológica do $\mathrm{N}_{2}$ tem sido o objetivo de muitas pesquisas, já que o maior reservatório natural desse elemento, a atmosfera, é praticamente inesgotável.

Em condições do solo, inúmeros são os fatores que poderão afetar adversamente a nodulação, limitando a posterior fixação do nitrogênio. Por isso, para fins práticos, estudos 
devem ser conduzidos sobre a comunidade de Bradyrhizobium spp que vêm estabelecendo-se nos solos do Estado de São Paulo, para melhor entendimento das interrelações entre rizóbios, solo e planta e adoção de medidas que aumentem a fixacão do $\mathrm{N}_{2}$. Resultados elucidativos das relações deste microorganismos com o seu macrosimbionte (a planta) e o seu habitat (o solo) têm sido obtidos em alguns trabalhos de identificação bacteriana através de técnicas imunológicas.

A identificação das bactérias naturalizadas e a determinação da porcentagem de nódulos que são formados pelas estirpes recomendadas como inóculo é de grande importância.

É também de fundamental importância conhecer a eficiência das estirpes de Bradyrhizobium japonicum naturalizadas que predominam nos nódulos formados nos cultivares mais plantados de soja afim de alcançar avanços que nos levem a otimização do processo de fixação simbiótica do Nitrogênio.

A inoculação de sementes de soja não é uma prática de uso generalizado no Estado de São Paulo. Não há estatística sobre uso de inoculantes, mas informações obtidas junto as indústrias produtoras dos mesmos, às cooperativas e à alguns agricultores sugere que o seu emprego é pequeno e com tendências a diminuir. Por outro lado, há indícios de que o uso de formulações com nitrogênio tende a aumentar (PACHECO \& PERES, Cooperativa dos Agricultores da Região de Orlândia Ltda, comunicação pessoal). As consequências dessa possível reversão tecnológica implicará em aumentos no custo de produção de grãos dessa leguminosa.

A tendência de abandonar a prática da inoculação está relacionada à nodulação natural generalizada, em locais previamente cultivado com soja, como ocorre em outros pontos do mundo e à ausência de observação de vantagens da inoculação com inoculantes comerciais nessas mesmas àreas. Isso pode ser atribuido à ocorrência de alto potencial de inóculos de estirpes ineficientes no solo e má qualidade de inoculantes.

Este trabalho teve como objetivo: a) Verificar a distribuição das estirpes naturalizadas e das recomendadas (SEMIA 587 e SEMII 5019) nos nódulos formados em lavouras de soja em áreas sobre rotação de soja com cana e soja com milho. b) Isolar rizóbios de estirpes adaptadas no Latossolo Roxo e testar, em carater preliminar, a 
eficiência das mesmas em comparação com as estirpes recomendadas para produção de inoculantes comerciais. c) Apurar se alguma estirpe isolada e identificada seria recomendada para uso em experimentos futuros. 


\section{REVISÃO DE LITERATURA}

Várias considerações apontam a fixação biológica do nitrogênio (FBN) como alternativa economicamente viável para a diminuição ou mesmo eliminação do uso de insumos nitrogenados em leguminosas. Além de financeiramente atraente, tal técnica oferece uma alternativa ecológica de redução dos impactos adversos causados pela aplicação excessiva daquele nutriente (BOHLOOL et al 1992).

Diversas pesquisas têm demonstrado os beneficios da inoculação das leguminosas. Em condições normais, 30 a $60 \%$ do nitrogênio requerido pela soja provém da fixação biológica (STREETER, 1973; HARDY et al,1975), dependendo da capacidade do solo em suprir nitrogênio. Entretanto, STREETER (1973) demonstrou que em condições ideais a simbiose poderia suprir até $100 \%$ do nitrogênio requerido pela soja.

Na FBN as leguminosas têm acesso ao nitrogênio atmosférico através da simbiose entre bactérias da familia Rhizobiaceae, dela fazendo parte os gêneros Rhizobium, Bradyrhizobium e Azorhizobium e plantas da família Leguminoseae. A associação ocorre quando as bactérias (microssimbionte) infectam as raízes das leguminosas (macrossimbionte) formando nódulos. Nesse trabalho, o termo rizóbio será utilizado para referir à bactérias dos três gêneros.

Dentro do nódulo as bactérias se transformam em bacteróides (morfológica, bioquímica e fisiologicamente diferente da bactéria de vida livre). Estes tomam o nitrogênio disponível às leguminosas, através da redução do $\mathrm{N}_{2}$ atmosférico, catalizada pela enzima nitrogenase. As células bacterianas permanecem envolvidas, isoladamente ou em grupos, por uma membrana chamada envelope membranoso (FREIRE, 1992).

Antes de iniciar o processo de fixação, ocorre a produção de um pigmento, a leghemoglobina, que tem função importante no transporte de oxigênio para a respiração dos 
bacteróides. Esta proteina mantém o oxigênio na forma associada, não permitindo a presença do oxigênio livre, que afetaria o funcionamento da nitrogenase (FREIRE, 1992).

Algumas leguminosas apresentam um considerável grau de especificidade em relação ao rizóbio específico mesmo antes do início da formação do nódulo e/ou fixação do nitrogênio.

O conjunto de espécie ou gênero de leguminosas capazes de formarem nódulos com uma determinada espécie de rizóbio caracteriza os grupos de inoculação cruzada. Sabe-se entretanto, que pode haver formação de nódulos entre rizóbios e leguminosas que caracterizam grupos diferentes.

Na cultura da soja, Glycine max (L.) Merrill, a FBN ocorre com alto grau de especificidade, mesmo ao nível de cultivares, com a espécie Bradyrhizobium japonicum (Lopes,1981). Esta especificidade entre bactérias e planta parece ser definida pela proteína lectina, presente nos pelos radiculares da planta e por um polissacarídeo da superfície bacteriana (FREIRE \& VIDOR, 1981).

Sendo a soja uma cultura exótica que foi introduzida no Estado de São Paulo em 1882, (MIYASAKA, 1958) e admitindo-se a necessidade da evolução da bactéria paralelamente à planta hospedeira susceptível de ser nodulada, parece pouco provavel que bactérias específicas para a soja sejam autóctones em nossos solos. Em experimentos realizados com solos do Estado de São Paulo, empregando o cultivar Santa Rosa, verificou-se ausência do Bradyrhizobium japonicum em solos com vegetação natural. Somente em áreas que já haviam sido anteriormente cultivadas com soja é que a nodulação foi positiva. Naqueles solos nunca cultivados com soja houve ausência de nódulos nas raízes desta leguminosa (LOPES et al, 1976 b).

Devido a ausência de Bradyrhizobium japonicum autóctone em nossos solos, recomenda-se que nos primeiros anos de cultivo da soja o agricultor proceda à prática da inoculação artificial com rizóbios específicos e de comprovada eficiência na fixação de nitrogênio (LOPES et al, 1976 a). A inoculação tem como objetivo levar a formação de nódulos infectados por rizóbios selecionados e estabelecer populações persistentes da bactéria inoculada no solo, afim de que possa assegurar uma expressiva fonte de inóculo para as culturas posteriores (BROCKWELL et al, 1989). 
Após 2 ou 3 anos de cultivo sucessivo com soja os microssimbiontes poderão se estabelecer no solo, proporcionando uma nodulação que pode ser abundante e eficiente, mesmo sem nova inoculação. Segundo FREIRE \& VIDOR (1981), enquanto o solo não alcançar uma população de $\mathbf{3 . 0 0 0}$ células de Bradyrhizobium japonicum por grama de solo seco uma nodulação satisfatória não estará garantida. Entretanto, SINGLETON \& TAVARES (1986), observaram que o número de rizóbios nativo afeta a resposta da planta à inoculação; estes autores verificaram que em áreas onde a comunidade nativa apresentava 20 rizóbios por grama de solo a resposta à introdução de novas estirpes não foi estatisticamente significativa.

AMARGER \& LOBREAU (1982), também mencionaram a importância da quantidade de rizóbios no solo como fator capaz de influenciar o processo de nodulação, relacionando a porcentagem de nódulos formados pela estirpes introduzidas com a concentração desta no inóculo. Porém, a inoculação com o microorganismo específico, mesmo que em concentração adequada, e comprovadamente eficiente, não dará a certeza de que uma simbiose satisfatória irá ocorrer, isso, porque alguns fatores poderão limitar o estabelecimento da simbiose e a fixação do nitrogênio (FREIRE \& VIDOR, 1981).

$\mathrm{O}$ pH do solo é um dos fatores que pode comprometer a FBN. Para a fixação do $\mathrm{N}_{2}$ atmosférico pela associação planta-bactéria, o pH ideal do solo é de 6,0 (TANAKA \& MASCARENHAS, 1992). Para a soja, o pH crítico, abaixo do qual não ocorre nodulação é de 4,0; geralmente, um valor de $\mathrm{pH}$ 8,5-9,0 é considerado como limite superior (VIDOR et al, 1983), esta condição contudo, é incomum em solos brasileiros, e praticamente inexistente nas áreas climaticamente adaptadas à cultura da soja (OLIVEIRA, J.B. Comunicação pessoal).

Os principais efeitos da acidez do solo dizem respeito à concentração do íon hidrogênio, deficiência de cálcio, fósforo e molibdênio, e excesso de alumínio e manganês. A acidez do solo afeta adversamente a sobrevivência, o crescimento e a fixação de $\mathrm{N}_{2}$, enquanto que problemas nutricionais afetam a simbiose leguminosarizóbios (LIE,1981 citado por BORDELEAU \& PROVOST,1994).

As espécies de rizóbios diferem quanto a tolerância de acidez do solo, os rizóbios, de crescimento lento são geralmente mais resistentes do que os de crescimento rápido, especialmente $R$. meliloti (MUNNS \& KEYSER, 1981). 
A elevada concentração de nitrogênio no solo, é outro fator que pode diminuir a eficiência da FBN. Alguns trabalhos sugerem que o nitrato apresenta efeito mais acentuado na formação dos nódulos, enquanto o íon amônia afeta mais o processo de fixação do $\mathrm{N}_{2}$ em si (MUNNS, 1977, citado por VARGAS et al, 1993).

Entretanto, no início da expansão da soja no Brasil, acreditava-se que quando aplicado em pequena quantidade ("nitrogênio de partida"), os efeitos do nitrogênio combinado poderiam ser benéficos logo nas primeiras semanas após a semeadura, periodo que antecede a ativa fixação de $\mathrm{N}_{2}$ nos nódulos. Atualmente não se faz recomendação para "nitrogênio de partida" (10-20 Kg/ha), pois pesquisas desenvolvidas evidenciaram que, não há resposta em termos de produção de grãos, à aplicação dessa pequena quantidade nem à altas doses de $\mathrm{N}_{2}$ (BARNI et al, citado por FREIRE, 1992).

Vários trabalhos (VARGAS \& SUHET 1982; VARGAS et al, 1982) demonstram a inutilidade da prática da adubação nitrogenada na semeadura da soja. VARGAS \& SUHET (1982), trabalharam com níveis de até $30 \mathrm{~kg}$ de N/ha e não observaram respostas à aplicação de fertilizantes nitrogenados. LOPES, E. S. (comunicação pessoal) constatou que em doses de $180 \mathrm{~kg}$ de N/ha não houve resposta a aplicação deste elemento químico, para produtividades superiores à $2500 \mathrm{Kg}$ de grãos/ha. LIMA (1995), observou que não houve resposta à $60 \mathrm{~kg}$ de $\mathrm{N} / \mathrm{ha}$ e houve diminuição da nodulação por influência do $\mathrm{N}$ aplicado. Não se recomenda adubação nitrogenada para a cultura da soja (RAIJ et al, 1985) já que a simbiose desta leguminosa com rizóbios por si só poderá garantir adequado suprimento de $\mathrm{N}_{2}$.

A quantidade de $\mathrm{N}_{2}$ fixado dependerá de fatores físicos do solo e do ambiente, da fertilidade e acidez do solo, da influência da aplicação de defensivos agrícolas, da eficiência e competitividade por sítio de infecção da bactéria fixadora, além de outros fatores.

Em condições naturais de solo vários fatores são limitantes à nodulação; por isso há necessidade de se utilizar como fonte de inóculos estirpes que tenham boa capacidade de colonizar e sobreviver em vários tipos de solos, e também que sejam de alta eficiência e elevada capacidade de competição por sítio de infecção nodular (FREIRE, 1981). As estirpes naturalizadas, as condições de crescimento da planta, e o método de inoculação 
além de outros fatores do solo, influenciam a habilidade competitiva das estirpes por sítio de infeç̧ão nodular.

LOPES (1981), referiu-se à estirpes naturalizadas como aquelas que após serem introduzidas sobrevivem no solo; essas estirpes podem sofrer mutações que levem a uma melhor adaptação ao solo em que foram introduzidas.

Segundo registros disponíveis no IPAGRO (VARGAS et al, 1993) as estirpes anteriormente utilizadas em inoculantes comerciais para soja, desde de 1956, foram as relacionadas a seguir com identificação do número SEMIA:

\begin{tabular}{ll}
\hline Ano & \multicolumn{1}{c}{ Esurpes (n` SEMIA) } \\
\hline 1956 & $516,517,519,512,513,521,525$ \\
1957 & $504,505,509,512,513,519,516$ \\
1958 & $504,505,509,512,513,514,515,517,519,521,522$ \\
1959 & $512,513,516,517,519,521,534,535$ \\
1960 & $511,512,513,516,517,521,525,527,530,534,535$ \\
1961 & $519,521,526,531,534,535$ \\
$1962 / 63$ & $509,510,513 R e, 519,527,531 R e$ \\
1964 & $504,513 R e, 531 R e, 527,543,506$ \\
1965 & $513 R e, 532 c, 504$ \\
$1966 / 67$ & $532 c, 543,566$ \\
1968 & $543,566,587$ \\
1969 & $562 \mathrm{c}, 543,566,587$ \\
1970 a 1976 & $527,523 \mathrm{c}, 566$ \\
1977 & $527,566,586$ \\
1978 & $527,532 \mathrm{c}, 566$ \\
1991 a 1979 & 587 e $29 \mathrm{~W}$
\end{tabular}

LOPES \& GIARDINI (1981), citaram que na década de 50 foram realizados trabalhos a campo com as estirpes introduzidas da Universidade de Illinois $\left(\mathrm{n}^{0} \mathbf{7 2 , 7 3 , 7 6}\right.$ e 376); Universidade de Wisconsin ( $\mathrm{n}^{0501}=\mathrm{SMS}-70,510$ e $515=$ SMS-71) e do Departamento de Agricultura dos Estados Unidos (USDA 3I1b11a = SMS-45 e USDA 
3I1b16a e uma estirpe originária do México, sem número de identificação = SMS-65). A 3I1b11a e a SMS-65 foram, empregadas na produção de inoculantes naquele período. Além disso, a estirpe SMS-64 (= SEMIA 5052 = 513Re), foi utilizada em inoculantes comerciais no Estado de São Paulo.

Atualmente, as firmas fabricantes de inoculantes utilizam as estirpes SEMIA $587=$ SMS-314; SEMIA 5019 (29W) = SMS-463; SEMIA 5079 (CPAC15) = SMS-783 e SEMII 5080 (CPAC7) = SMS-784 oficialmente recomendadas para a cultura de soja.

Estirpes naturalizadas (eficientes ou ineficientes) de Bradyrhizobium japonicum ocupam sítios de infecção nodular em proporções desconhecidas competindo com os rizóbios atualmente recomendados para uso em inoculantes. Sendo assim, a presença de estirpes de rizóbios nos nódulos pode não estar relacionada com a estirpe utilizada no inoculante (KOLLING et al, 1976). A ocorrência de solos com dominância de estirpes de baixa eficiência e alta competitividade, poderia vir a limitar os tetos de produtividade da soja (VARGAS et al, 1993).

HAM et al (1971) observaram no Estado de Minesota, EUA, que não houve aumento significativo da produção da soja através da inoculação artificial de até 3400 rizóbios por semente em solos onde havia população estabelecida de rizóbios, sugerindo que nem sempre uma alta taxa de inoculante leva a um aumento de nódulos formados por estirpes do inoculante, bem como a uma maior produção da soja.

WEAVER \& FREDERICK (1974) observaram que para se obter 50\% de nódulos de soja com a estirpe introduzida, o número de rizóbios no inoculante deveria ser 1000 vezes maior que o do solo. Estes mesmos autores observaram que, em solo cuja população de rizóbios naturalizados, capazes de nodular a soja, era maior que 1000 cél./g de solo seco a inoculação com estirpes introduzidas não aumentou a nodulacão. Após uma população de rizóbio ter se estabelecido no solo, a inoculação com estirpes recomendadas tem que competir e superar a persistência dos rizóbios naturalizados na formação de nódulos e posterior fixação do nitrogênio. Obviamente o conhecimento da eficiência de fixação de $\mathrm{N} 2$ das estirpes naturalizadas que ocorrem com maior frequência nos nódulos se faz necessário. 
A resposta à inoculação dependerá também da qualidade do inoculante empregado, sendo esta aferida pela eficiência das estirpes de rizóbios utilizadas na fabricação e pelo número de células existentes desta bactéria por unidade de peso do produto. Segundo a lei federal 6934 de 13/7/91, o inoculante deve apresentar 100 milhões de rizóbios por grama do produto se a amostra for coletada na unidade produtora e 10 milhões de rizóbios por grama se for coletada em um estabelecimento comercial. $O$ uso de doses mais baixas de inoculante após o primeiro cultivo da soja ainda é recomendado pelos orgãos de pesquisa, apesar de não haver estudos que suportem essa recomendação (VARGAS et al, 1993).

KAMICKER \& BRILL,(1986) citaram que os rizóbios podem persistir no solo sem a cultura da soja por pelo menos 30 anos. Outros trabalhos também indicaram que esta bactéria pode persistir no solo na ausência da leguminosa hospedeira (KAMICHER \& BRILL, 1987), contudo, tais trabalhos não apresentaram dados relacionados a magnitude da comunidade no solo. KUCEY \& HYNES (1989) examinando populações de Rhizobium leguminosarum bv. phaseoli e R. leguminosarum bv. viceae na rotação de feijão ou ervilha, respectivamente, com plantas não leguminosas, encontraram que o número dessas bactérias específicas era significativamente menor na ausência da planta hospedeira. Porém, TRIPLETT et al (1993) observaram que a espécie $B$. japonicum é muito persistente, não sendo muito afetada em rotação de soja com milho.

O efeito benéfico da associação simultânea, ou em sucessão, de leguminosas e outras culturas, constituiu assunto de estudo por parte de diversos autores (SUTHERLAND et al,1961 e VEST, 1971). Porém, pouca informação se tem a respeito das populações de rizóbios nas rotações de culturas mais empregadas no cultivo da soja. Sabe-se que o benefício da consorciação de leguminosas com gramíneas, baseia-se na transferência do nitrogênio fixado pela leguminosa para a gramínea associada (FREIRE, 1992).

$O$ aproveitamento pelas culturas de milho, trigo e arroz do nitrogênio residual transferido pela soja ao solo em substituição a adubação nitrogenada foi estudado por MASCARENHAS et al (1983). Os dados experimentais encontrados por esses autores mostraram a suficiência de nitrogênio acumulado após anos sucessivos de cultivo com soja, tomando desnecessária a aplicação suplementar desse nutriente para o milho e, 
consequentemente, colaborando para diminuir o custo de um dos fatores que oneram a produção; dados semelhantes foram encontrados para o trigo e arroz.

SCHRODER \& HINSON (1975), citados por MASCARENHAS et al (1983), relataram que apenas as raízes e os nódulos de soja transferem ao solo cerca de $20 \mathrm{Kg} / \mathrm{ha}$ de $\mathrm{N}_{2}$. Estas quantidades fornecem 25 a $60 \%$ do nitrogênio total das plantas adultas bem noduladas.

Estudos que procurem identificar a biodiversidade e a magnitude da população de rizóbios no solo sob diferentes rotações de cultura poderão fornecer resultados importantes para a determinação dos fatores que afetam a inoculação artificial.

$\mathrm{Na}$ investigação da competitividade, a capacidade de distinguir entre estirpes faz-se necessária, e a interpretação de dados da inoculação da leguminosa à campo, frequentemente auxiliada pela capacidade de determinar a proporção relativa de nódulos radiculares ocupados pelos rizóbios do inóculo e pelos tipos indigenas.

Apesar da produção de soja no Brasil ser de grande importância econômica, pouco se sabe sobre a taxonomia das estirpes usadas para a inoculação desta leguminosa.

RUMJANEK (1993), observando características de especificidade hospedeira, clorose foliar, resistência intrinseca à antibiótico, sequêcia de DNA, reação sorológica, sequência nucleotídica de genes RNAr 16S, encontraram semelhanças entra as estirpes 29W e 587 com as USDA-76 e USDA-31 respectivamente que são classificadas como B.elkanii. NEVES et al (1985), citado por RUMJANEK (1993) observaram que as estirpes 29 W e 587 são Hup- como é o caso de outras estirpes da espécie $B$. elkanii.

Vários métodos tem proporcionado informações sobre a estrutura química e taxonômica para identificação das estirpes de rizóbios. Geralmente, os métodos utilizados consideram: a) propriedades de membrana tais como interação lectina-planta, sorologia, fagotipagem e marcas de resistência a antibiótico (EAGLESHAM \& SINCLAIR, 1988); b) propriedades metabólicas como a utilização de carboidratos e necessidade de vitaminas, além da produção de álcali ou ácido "in vitro" e o tempo de geração; c) respostas fisiológicas de tolerância à temperatura, à salinidade, à acidez, alcalinidade etc. 
Em pesquisas que requerem a caracterização da diversidade de população nativas do solo, técnicas rápidas e simples são desejáveis para a identificação de nódulos ou isolados em grandes volumes.

A sorologia tem sido uma das técnicas mais utilizadas pelo seu baixo custo e simplicidade, e tem sido superada somente pela eletroforese de gel para proteínas como técnica com alto poder discriminativo.

OLSEN \& RICE (1989) descreveram a técnica sorológica "immunodot" que utiliza nitrocelulose como um suporte para a imobilização do antígeno de rizóbio, em uma forma de ELISA indireto. Bastante empregada em estudos de levantamento da população nativa e viabilidade de células de rizóbios em inoculantes, a técnica "immunodot", apesar de uma importante ferramenta no estudo da rizobiologia, tem a desvantagem de somente identificar sorogrupos, e neste aspecto incluem-se todas as técnicas sorológicas-testes de aglutinação, imunodifusão, imunofluorescência e ELISA (enzyme linked immunosorbent assay) que associa sorologia e reação enzimática (EAGLESHAM \& SINCLAIR, 1988).

Os lipopolissacarídeos da parede bacteriana apresentam reconhecida atividade imunogênica, sendo que, a estreita correlação existente entre os padräes de LPS em SDSPAGE e os sorogrupos de rizóbios sugerem a possibilidade de se utilizar estas biomoléculas na obtenção de soros hiperimunes monoespecificos que levem a uma melhor distinção entre os diferentes sorogrupos desta bactéria (LEMOS, 1994).

O conjunto das informações obtidas pelos métodos citados acima permite juntamente com metodologias mais sensíveis, tais como eletroforese em géis de poliacrilamida (LEMOS et al, 1990), RFLP (restriction fragment length polymorphisms), PCR (polimerase chain reaction e RAPD (random amplified polymorphic DNA), identificar com maior precisão um maior número de linhagens de Bradyrhizobium spp (HADRYS et al, 1992). 


\section{MATERIAL E MÉTODOS}

As coletas de nódulos foram efetuadas nos dias 27,28 e 29 de janeiro de 1992 em propriedades agrícolas localizadas nos municípios de Guará, Morro Agudo, Ipuã, São Joaquim da Barra, Ituverava e Orlândia (municípios da Divisão Regional Agrícola -DIRAde Franca), além de Barretos e Ribeirão Preto (respectivamente DIRA de Barretos e Ribeirão Preto).

\subsection{Amostragem a campo}

\subsubsection{Local e número de coletas}

Foram efetuadas 20 coletas de amostra de nódulos e solos em propriedades com cultivo de soja, sendo $10 \mathrm{em}$ área de renovação de cana de açúcar (Saccharum officinarum L.) onde esta gramínia permanece no terreno por até 6 anos, sofrendo cortes sucessivos; as outras 10 foram em área de rotação com milho (Zea mays L.) de safrinha, onde essa gramínea é cultivada no mesmo ano agrícola da soja.

As 20 propriedades amostradas estão identificadas na tabela 1 . 
Tabela 1. Identificação dos locais das coletas de amostras de solo e nódulos em áreas de rotação soja/milho e soja/cana.

\begin{tabular}{|c|c|c|}
\hline Nủmero & Nome da propriedade & Município \\
\hline \multicolumn{3}{|c|}{ A - Rotação soja/milho } \\
\hline 1 & Água Corrente & Guará \\
\hline 2 & São José & Guará \\
\hline 3 & Na. Sa. Aparecida & Guará \\
\hline 4 & Santa Cecília & Guará \\
\hline 5 & Santo Antônio & Guará \\
\hline 6 & São Gabriel & Ituverava \\
\hline 7 & Olhos D'água & Ipuã \\
\hline 8 & São Marcos & Ipuã \\
\hline 9 & Abelha & Ipuã \\
\hline 10 & Formiga & Ipuã \\
\hline \multicolumn{3}{|c|}{ B- Rotação soja/cana } \\
\hline 11 & Santa Ruth & São Joaquim da Barra \\
\hline 12 & Marimbondo & São Joaquim da Barra \\
\hline 13 & Taboa & Orlândia \\
\hline 14 & Três Divisas & São Joaquim da Barra \\
\hline 15 & Olaria & Morro Agudo \\
\hline 16 & Cerva Branca & Barretos \\
\hline 17 & Saudade & Ribeirão Preto \\
\hline 18 & Perobinha & São Joaquim da Barra \\
\hline 19 & Bonanza & Morro Agudo \\
\hline 20 & Samambaia & Orlândia \\
\hline
\end{tabular}




\subsubsection{Histórico das áreas amostradas}

Foram efetuadas coletas de informações sobre o histórico de uso das áreas e sobre as lavouras de soja amostradas, de acordo com um quetionário modelo (apêndice 1). Na maioria dos casos essas informaçães foram tomadas no dia da coleta, em entrevista com o administrador, ou com o proprietário realizada pelo colaborador do projeto Engenheiro Agrônomo da CAROL (Cooperativa dos Agricultores da Região de Orlândia) Luís André Pazzeto; em algumas áreas a entrevista foi posterior à coleta.

\subsubsection{Coleta de nódulos}

Em cada local de amostragem foi definida uma área com $1.000 \mathrm{~m}^{2}$, representativa da lavoura consistindo de $\mathbf{4 0}$ linhas de $\mathbf{5 0} \mathrm{m}$ deixando-se uma bordadura de pelo menos $8 \mathrm{~m}$ da estrada de acesso à área. Quatro pontos de amostragem com intervalos regulares de 12,5 $\mathrm{m}$ foram definidos para se efetuar coletas em 5 linhas. Foram amostradas 2 plantas por ponto, perfazendo-se portanto 8 por linha e 40 por local.

Em cada ponto de amostragem, a parte aérea das plantas foi cortada e as raízes foram arrancadas cuidadosamente com enxadão, aprofundando-se ao máximo para remover a maior parte do sistema radicular. A parte aérea foi desprezada e a raiz separada para posterior observação e retirada dos nódulos no laboratório.

Definiu-se inicialmente que de cada amostra seriam separados pelo menos 20 nódulos. Parte desses nódulos foram reservados para isolamento de prováveis rizóbios,e outra parte para caracterização das estirpes em suspensão de nódulos. Para a caracterização das estirpes nos nódulos, selecionou-se 2 nódulos por ponto de amostragem ( $2 \times 20=40$ nódulos por propriedade).

\subsubsection{Separação e armazenamento dos nódulos}

Durante os dias de coleta e até finalizar a separação dos nódulos no laboratório, as raízes amostradas foram mantidas sob refrigeração. 
No laboratório os nódulos foram manualmente destacados das raízes e colocados em frascos de vidro (aproximadamente 20 nódulos/ponto de amostragem) com solução aquosa de glicerol a $20 \%$, os quais, devidamente identificados, por ponto de amostragem, foram armazenados a uma temperatura de $-20^{\circ} \mathrm{C}$.

\subsubsection{Caracterização e amostragem do solo}

Todas as amostragens foram efetuadas em cultivo da soja em Latossolo Roxo. A escolha das propriedades foi feita com base na sua localização preliminar no mapa do levantamento detalhado de solos da área de atuação da Usina do Rosário (PRADO, 1993). Entretanto, antes de se proceder as coletas foi feito, em cada área de amostragem, um teste de atração de amostras do solo da superficie por um imã para confirmar se se tratava de Latossolo Roxo . Em todos locais foi observado que as amostras de solo da superfície foram fortemente atraídas pelo imã, o que permitiu confirmar tratar-se de Latossolo Roxo.

Em cada área definida foram coletadas 4 sub-amostras de solo $(0-20 \mathrm{~cm}$ de profundidade) em 4 dos 20 pontos de coleta de nódulos, definidos ao acaso, para fins de análises químicas. As subamostras, coletadas próximas às raízes das plantas, foram colocadas num saco plástico e homogeneizadas. Uma porção foi separada e encaminhada à Seção de Fertilidade do Solo e Nutrição de Plantas do IAC para análises químicas.

\subsection{Isolamento de rizóbios que nodulam soja}

Foram realizados 99 isolamentos de bactérias dos nódulos coletados segundo a técnica proposta por SOMASEGARAM \& HOBEN (1985) com algumas modificações. Os nódulos foram desinfectados superficialmente pela imersão por 4 minutos, em solução de hipoclorito de sódio 3:1. Em seguida, foram lavados por 6 vezes com água destilada esterilizada, e macerados em tubos de ensaio contendo um volume de $2-3 \mathrm{ml}$ de água esterilizada, obtendo-se uma suspensão de bactérias. Uma alíquota dessa suspensão foi transferida para placas contendo meio manitol-extrato de levedura (apêndice 2), e estas foram incubadas a $28^{\circ} \mathrm{C}$ por 6-14 dias. As colônias com morfologia típica de rizóbio foram sucessivamente riscadas em novas placas até obtenção de culturas de um único tipo morfológico das prováveis estirpes de rizóbios. Em alguns casos mais de um tipo 
morfológico foi isolado a partir de um único nódulo, sendo esses casos devidamente anotados e as culturas identificadas.

As culturas puras foram armazenadas em tubos de ensaio com meio de cultura sólido manitol-extrato de levedura com azul de bromotimol (apêndice 2) sob óleo, sendo preservadas à temperatura ambiente.

As 99 culturas isoladas foram submetidas a teste preliminar de eficiência e nodulação, e testes de aglutinação e eletroforese, para identificação das mesmas.

3.2.1. Teste preliminar de eficiência e nodulação:

Para a autenticação das culturas isoladas como bactérias provavelmente pertencentes ao gênero rizóbio, fez-se a inoculação de cada uma delas em soja IAC-8 cultivada em solução nutritiva com apenas $20 \mathrm{mg} \mathrm{N} / v a s o$ (apêndice 3) em experimento conduzido em casa de vegetação, utilizando-se de vasos de Leonard como descritos por SOMASEGARAN \& HOBEN (1985) . Utilizou-se o delineamento experimental completamente casualizado sem repetição.

Foram realizados 4 testes sendo o primeiro com 45 isolados, o segundo com 31, o terceiro com 39 e o quarto com 6 isolados. Foram mantidos 2 controles sem inoculação, sendo um sem nitrogênio $(C)$ e outro com nitrogênio $(C+N)$. $O$ controle sem nitrogênio foi introduzido para assegurar que o manuseio no momento das inoculações e durante a condução foi satisfatório, pela ausência de nódulos; e o controle com nitrogênio para constatar que a solução nutritiva estava adequada, julgando-se pelo desenvolvimento normal das plantas. Somente tiveram repetições os tratamentos $\mathrm{C}$ e $\mathrm{C}+\mathrm{N}$, além das estirpes recomendadas SEMIA- 587 e SEMIA-5019 usadas como padrão. O tratamento $\mathrm{C}+\mathrm{N}$ recebeu $300 \mathrm{mg}$ desse nutriente parcelado em seis aplicações de uma solução de $\mathrm{NH}_{4} \mathrm{NO}_{3}(0,74 \%$ de $\mathrm{N})$. Além de verificar a presença ou ausência de nódulos, objetivouse neste teste, obter informações preliminares de eficiência de fixação de nitrogênio dos rizóbios isolados. Para tanto, as plantas foram cultivadas por um período de 50 a 54 dias.

As plantas do primeiro teste foram colhidas aos 54 dias após o plantio (DAP); as do segundo aos 50 DAP, e as do terceiro e quarto com 52 DAP. 
Após a colheita a parte aérea foi separada do sistema radicular e os nódulos foram retirados e contados. Secaram os nódulos e a parte aérea à $60^{\circ} \mathrm{C}$ até peso constante e posteriormente ambos foram pesados.

A análise estatística para comparação das médias de eficiência relativa entre propriedades, sistema de cultivos e sorogrupos, foi feita pelo programa de computador SAS- Statistical Analysis Sistem com teste de significância Dunkan a 5\%. As variáveis com menos de dois dados foram desprezadas (propriedade $\mathrm{n}^{0} 15$, tabelas 12 e 13 e sorogrupos VIII e IX, na rotação soja/cana, tabela 15).

\subsection{Caracterização dos nódulos e isolados}

Para identificação das estirpes nos nódulos foram feitos testes com nódulos intactos utilizando-se a técnica imunológica "immunodot" (OLSEN \& RICE; 1989).

Para identificação das estirpes já isoladas, foram realizados testes sorológicos de aglutinação com células inteiras. As estirpes não identificadas por este teste foram submetidas a teste com soros hiperimunes produzidos com lipopolissacarídeos (LPS). Os soros hiperimunes utilizados para os teste de aglutinação e "immunodot" foram fornecidos pelo Departamento de Tecnologia da UNESP/Jaboticabal.

As culturas que não puderam ser caracterizadas pelos testes de aglutinação foram submetidas ̀̀ análise eletroforética em SDS-PAGE (Sodium dodecyl sulfatepolyacrilamide gel electrophoresis).

3.3.1.Teste de aglutinação e eletroforese (caracterização das culturas puras):

As culturas puras de rizóbios, isoladas de nódulos coletados nas vinte propriedades amostradas foram primeiramente testados por aglutinação com soros hiperimunes de células inteiras, pertencentes a oito sorogrupos distintos. Os soros hiperimunes utilizados estão identificados na tabela 2 pelo grupo sorológico adotado no IPAGRO-RG; número SEMIA; número de origem de estirpes, nos casos referentes à introduções de outros laboratórios e número USDA. 
Os sorogrupos que apresentaram reações cruzada durante os testes de aglutinação com soros hiperimunes produzidos com células inteiras de rizóbios [sorogrupos II (SEMIA 5025); III (SEMIA 587) e IV (SEMIA 5019)] foram selecionados para o teste de aglutinação com soros hiperimunes anti-LPS.

Tabela 2. Relação dos sorogrupos, número SEMIA e identificação de origem das estirpes de rizóbios utilizadas em teste de aglutinação com soro hiperimune de células inteiras.

\begin{tabular}{lcl}
\hline Sorogrupo & Número & \multicolumn{1}{c}{ Identificação de origem (3) } \\
& SEMIA & \\
& & \\
I & 5052 & USDA 6 (USDA C1) \\
II & 5025 & TAL 411 \\
III & 587 & original IPAGRO \\
IV & 5019 & 29W (USDA 76) \\
V & 5080 & CPAC-7, subcultura da SEMIA586 (USDA 122) \\
VI & 566 & Isol. 31/66 de Inoc.Com. DIXIE (USDA 123) \\
VIII & 5061 & INPA 037 \\
IX & 518 & UW518, USDA 10
\end{tabular}

(1) Identificação segundo IPAGRO

(2) Número de catálogo do IPAGRO - Porto Alegre - RS

(3) Entre parênteses identificação do sorogrupo encontrada na literatura segundo DATE \& BECKER (1965) e KEYSER \& WEBER (1979).

\subsubsection{Preparo das amostras:}

a) Para testes de aglutinação

As 91 culturas a serem testadas foram ajustadas a uma concentração de 200 unidades Kletts o que corresponde a uma densidade óptica de $0,4 \mathrm{~nm}$. Os soros hiperimunes e as culturas a serem identificadas foram postos a reagir em placas de Takatsi com fundo em "V" em concentrações de 1:1 e mantidos por três minutos em agitador orbital. Para facilitar a observação das reações de aglutinação coloriu-se com algumas 
gotas de cristal- violeta as culturas antígenos. Fez-se a leitura das placas com auxílio de um negatoscópio com fundo branco após 24 horas de repouso das mesmas em temperatura ambiente. O procedimento para os testes de aglutinação com células inteiras e para aglutinação com anti-LPS foi igual, variando-se somente o soro hiperimune.

b) para testes de eletroforese

As culturas puras não identificadas por aglutinação, foram cultivadas em meio de cultura líquido, YMB (apêndice 2), durante 4 dias a $28^{\circ} \mathrm{C}$, sob agitação até atingirem a fase log. Depois foram centrifugadas em Ependorf a 1800x g/20min. , lavadas em $0,5 \mathrm{ml}$ de $\mathrm{NaCl}$ a $0,85 \%$, e centrifugadas novamente por 5 minutos (SPIN I-15.000 rpm). O precipitado foi ressuspendido em $0,5 \mathrm{ml}$ de $\mathrm{NaCl}$ a $0,85 \%$ e transferido para um tubo de ensaio onde a concentração foi ajustada para 400 unidades Kletts $(=0,8 \mathrm{~nm})$. Posteriormente, $1 \mathrm{ml}$ de cada suspensão, foi aquecida em banho-maria por 45 minutos a uma temperatura de $95^{\circ} \mathrm{C}$. Após o aquecimento, centrifugou-se a $16.000 \mathrm{x}$ g por 5 minutos, e retirou-se $0,4 \mathrm{ml}$ do sobrenadante ao qual adicionou-se $0,1 \mathrm{ml}$ de tampão da amostra (apêndice 4). Ferveu-se por 8 minutos 0,70 a $0,75 \mu 1$ de cada preparação, e estas foram submetidas a eletroforese em gel de poliacrilamida (LEMOS, 1994).

\subsubsection{Preparo do Gel de Poliacrilamida:}

Os géis de poliacrilamida continham $1 \%$ em SDS utilizando-se $5 \%$ de gel concentrador e $13 \%$ de gel de separação (apêndice 4). Foram utilizadas placas com dimensões de $18 \mathrm{~mm} \times 16,5 \mathrm{~mm} \times 1 \mathrm{~mm}$ e a eletroforese foi desenvolvida mantendo-se a corrente constante $(20 \mathrm{~mA})$ até a entrada do corante no gel de separação, quando então foi aumentada para $25 \mathrm{~mA}$ e assim mantida até o final da corrida.

\subsubsection{Detecção por nitrato de prata}

Após a eletroforese os géis foram imersos em solução aquosa $40 \%$ em etanol e $5 \%$ em ácido acético, durante a noite, e submetidos a oxidação com $0,7 \%$ de ácido periódico, adicionado à solução fixadora. 
Após quatro lavagens sucessivas de 15 minutos com $\mathrm{H}_{2} \mathrm{O}$ desionizada, os géis foram tratados com o "reagente de cor" (apêndice 4), lavados com água desionizada ( $3 \mathrm{x}$ 30 minutos) e revelados com solução de formaldeido (apêndice 4), (TSAI e FRASCH, 1982). Após o aparecimento das bandas ( 2 a 3 minutos) os géis foram lavados rapidamente com água desionizada com $30 \mathrm{ml}$ de ácido cítrico $1 \mathrm{M}$, por 30 segundos, para interromper a ação do revelador.

Os géis foram então imersos em água desionizada e documentados fotograficamente.

Todas as etapas do processo de coloração de lipopolissacarídeos foram realizadas sob agitação suave e na ausência de luz.

3.3.2.Teste de "immunodot" (caracterização das suspensões dos nódulos):

Foram testados 40 nódulos de cada uma das amostras das 20 propriedades. Os nódulos foram testados com os soros hiperimunes produzidos a partir de células inteiras das estirpes SEMIA-566 (sorogrupo VI), SEMIA-587(sorogrupo III), SEMIA5019(sorogrupo IV) e SEMIA-5052 (sorogrupo I). Esses soros hiperimunes foram produzidos por meio de imunização de coelhos, no Departamento de Tecnologia da UNESP/Jaboticabal.

Os soros hiperimunes escolhidos para a caracterização dos nódulos foram testados quanto a especificidade de grupos sorológicos através da técnica do "immunodot" onde utilizou-se como antígeno as culturas puras homólogas de cada soro hiperimune (tabela 3). 
Tabela 3. Análise da especificidade dos soros hiperimunes com as culturas SEMIA.

\begin{tabular}{|c|c|c|c|c|c|}
\hline \multirow{2}{*}{$\begin{array}{l}\text { Estirpes } \\
\text { (SEMIA) }\end{array}$} & \multicolumn{5}{|c|}{ Soros hiperimunes (SEMIA) } \\
\hline & 566 & 587 & 5019 & 5052 & \\
\hline 566 & + & & & & \\
\hline 587 & & + & & + & + \\
\hline 5019 & & & + & & + \\
\hline 5052 & & & & + & \\
\hline
\end{tabular}

O sinal + indica forte reação

Como o conjugado (controle) apresentou reação positiva com dois soros hiperimunes, fez-se a sua adsorção, como se mostra a seguir:

- retirou-se 100 $\mu$ d do conjugado e acrescentou-se em $400 \mu$ de PBS (diluido 5x);

- retirou-se 1000ul de cada cultura (SEMIA 587 e SEMIA 5019) e centrifugou-as $(9.000 \times \mathrm{g} / 10 \mathrm{~min}$.) separadamente, os sobrenadantes foram descartados;

- adicionou-se $500 \mu$ do conjugado em um dos tubos com o precipitado de células, resuspendeu-o; adicionou-se a suspensão no outro tubo, homogeneizando a mistura;

- agitou-se essa mistura (conjugado + culturas), em um agitador tipo gangorra por 4 horas a temperatura ambiente;

- em seguida centrifugou-se a mistura (9.000 $\mathrm{x}$ g/10min.) e guardou-se em "freezer" o conjugado adsorvido (sobrenadante); 
- testou-se esse conjugado, pela técnica do "immunodot" e verificou-se que não mais reagia com os soros hiperimunes SEMIA 587 e SEMIA 5019.

Os nódulos foram retirados do "freezer", descongelados e desinfestados com hipoclorito de sódio (1:3) e lavados com água estéril.

Cada nódulo foi separadamente macerado em solução fisiológica ( $\mathrm{NaCl} 0,85 \%)$, num volume que variou de 750 a $2000 \mu$ de acordo com o tamanho dos nódulos.

Uma alíquota de 1-5 $\mu$ da suspensão de nódulos, foi transferida sobre as membranas de nitrocelulose (SIGMA-N-2764). As membranas foram deixadas a secar a temperatura ambiente e então bloqueou-se a área sem bactérias banhando-se as membranas em leite diluído a 5\% em PBS (apêndice 4), durante 15 minutos sem agitação. Inativou-se a peroxidase endógena das bactérias em solução de $\mathrm{H}_{2} \mathrm{O}_{2}$ 10V diluído em PBS na proporção de 1:9, por 10 minutos.Retirou-se a água oxigenada lavando-se as membranas por 3 vezes com leite desnatado diluído a 5\% em PBS. As lavagens foram realizadas sob agitação por um período de 5 minutos cada. Cada membrana foi incubada sob agitação moderada por 1 hora com cada um dos soros hiperimunes diluidos no leite desnatado (soros hiperimunes SEMIA 566, SEMIA 587 e SEMIA 5019 diluidos 1: 3000 e soro hiperimune SEMIA 5052 diluido 1:2000). A membrana controle permaneceu durante este período em PBS. Posteriormente, as membranas (inclusive a controle), foram lavadas por 3 vezes em PBS, sob agitação por 5 minutos. A seguir foram incubadas com $o$ soro hiperimune anti IgG de coelho conjugado a peroxidase, diluído 1:3000 em leite a 5\% diluído em PBS, durante 1 hora, sob agitação moderada e a temperatura ambiente. Após o período de incubação, as membranas foram lavadas 3 vezes em PBS por 5 minutos e incubadas em solução reveladora contendo 100ul de solução de cloronaftol (vide apêndice 4) $+10 \mu \mathrm{l}$ de $\mathrm{H}_{2} \mathrm{O}_{2} 30 \%+10 \mathrm{ml}$ de Tris $50 \mathrm{mM}$ durante 5-10 minutos. Após a revelação, as membranas foram lavadas em PBS e postas a secar em temperatura ambiente. 


\section{RESULTADOS E DISCUSSÃO}

\subsection{Histórico das áreas amostradas}

As informações a respeito do histórico das áreas das lavouras onde se fez as 20 amostragens de nódulos foram extraídas das respostas dos proprietários ou administradores a um questionário previamente elaborado (apêndice 1).

O resultado da análise das características de amostras de solo coletadas nas 20 propriedades na região amostrada são apresentados no Tabela 4.

Os valores médios de $\mathrm{pH}$ para rotação soja/milho $(\mathrm{pH}=5,75)$ e para soja/cana $(\mathrm{pH}=5,51)$ podem ser considerados adequados para o cultivo da soja. $\mathrm{Na}$ área soja/cana quatro propriedades apresentaram $\mathrm{pH}$ menor que 5,5 sendo que numa propriedade ( $\mathrm{n}^{\mathrm{O}}$ 16) $\circ \mathrm{pH}$ foi inferior a 5,0 .

A metade das propriedades apresentou amostras de solo com teores de fósforo considerados por TANAKA \& MASCARENHAS (1992) como médios $\left(16-40 \mu \mathrm{cm}^{3}\right)$, enquanto que as restantes apresentaram teores altos $\left(41-80 \mu \mathrm{g} / \mathrm{cm}^{3}\right)$ ou muito altos $(>80$ $\mu \mathrm{g} / \mathrm{cm}^{3}$ ). A média desses valores na área de rotação soja/milho foi 75,9 e na soja/cana 36,6 .

Quanto aos resultados obtidos para saturação por bases, a maioria (65\%) das propriedades apresentou amostras de solo com teores médios (51-70\%) repartindo-se as restantes por valores muito baixos (0-25\%), baixos (26-50\%) e altos (71-90\%), denotando-se necessidade de calagem. Em termos médios a saturação de base foi maior (66\%) na área soja milho do que na soja/cana (56\%). 
Tabela 4. Análises químicas de características de amostras de solo de lavouras de soja, coletadas $(0-20 \mathrm{~cm}) \mathrm{em} 20$ propriedades em áreas com rotação soja/milho e soja/cana. Médias de quatro repetições.

$\begin{array}{ccccccccccc}\begin{array}{c}\mathrm{N}^{0} \mathrm{da} \\ \text { propriedade }\end{array} & \mathrm{P} & \text { M.O. } & \underset{\mathrm{CH}}{\mathrm{CaCl} 2} & \mathrm{~K} & \mathrm{Ca} & \mathrm{Mg} & \mathrm{H}+\mathrm{Al} & \mathrm{S} & \mathrm{T} & \mathrm{V} \\ \end{array}$

$\mu \mathrm{g} / \mathrm{cm}^{3} \quad \%$

$----c m o l(+) . \mathrm{Kg}^{-1}$ TFSA-------- $\%$

\begin{tabular}{crrrrrrrrrr}
\multicolumn{1}{c}{ A- Rotação soja/milho } & & & & & & & & \\
1 & 165,6 & 3,5 & 5,9 & 0,22 & 5,0 & 1,2 & 2,5 & 6,4 & 8,9 & 71 \\
2 & 60,5 & 3,5 & 5,7 & 0,12 & 3,0 & 1,1 & 3,1 & 4,2 & 7,3 & 57 \\
3 & 47,8 & 3,9 & 5,6 & 0,33 & 4,6 & 1,1 & 3,4 & 6,0 & 9,4 & 64 \\
4 & 87,8 & 4,3 & 6,2 & 0,32 & 7,6 & 1,7 & 2,1 & 9,7 & 11,6 & 82 \\
5 & 132,5 & 3,6 & 5,9 & 0,22 & 4,8 & 1,1 & 2,5 & 6,2 & 8,7 & 70 \\
6 & 113,5 & 3,5 & 5,7 & 0,24 & 4,1 & 1,0 & 2,8 & 5,3 & 8,1 & 65 \\
7 & 34,0 & 4,9 & 5,3 & 0,22 & 3,8 & 1,1 & 4,4 & 5,1 & 9,5 & 54 \\
8 & 43,5 & 4,9 & 5,7 & 0,32 & 4,8 & 1,1 & 3,0 & 6,2 & 9,2 & 67 \\
9 & 22,8 & 5,0 & 5,6 & 0,14 & 3,7 & 1,1 & 3,6 & 4,9 & 8,6 & 57 \\
10 & 51,3 & 4,3 & 5,9 & 0,13 & 4,6 & 1,4 & 2,6 & 6,1 & 8,7 & 70
\end{tabular}

\section{B- Rotação soja/cana}

$\begin{array}{rrrrrrrrrrr}11 & 22,8 & 4,0 & 5,1 & 0,29 & 2,6 & 0,6 & 4,9 & 3,4 & 8,3 & 41 \\ 12 & 29,0 & 3,3 & 5,4 & 0,26 & 2,2 & 0,8 & 3,6 & 3,3 & 6,8 & 48 \\ 13 & 36,0 & 4,7 & 5,6 & 0,17 & 4,3 & 1,1 & 3,3 & 5,6 & 8,9 & 63 \\ 14 & 20,5 & 5,2 & 6,0 & 0,34 & 6,6 & 1,7 & 2,6 & 8,7 & 11,3 & 77 \\ 15 & 25,8 & 4,1 & 5,3 & 0,21 & 2,7 & 0,9 & 3,9 & 3,9 & 7,8 & 49 \\ 16 & 26,5 & 4,4 & 4,5 & 0,28 & 1,1 & 0,5 & 5,8 & 1,8 & 7,7 & 24 \\ 17 & 19,5 & 3,7 & 5,9 & 0,13 & 3,1 & 1,4 & 2,8 & 4,6 & 7,4 & 62 \\ 18 & 43,8 & 3,8 & 5,8 & 0,17 & 4,9 & 1,2 & 2,9 & 6,3 & 9,2 & 69 \\ 19 & 34,0 & 4,6 & 5,6 & 0,13 & 2,8 & 1,1 & 3,8 & 4,0 & 7,8 & 52 \\ 20 & 108,0 & 3,6 & 5,9 & 0,19 & 4,4 & 1,6 & 2,7 & 6,1 & 8,8 & 70\end{array}$


Os teores de matéria orgânica variaram de 3,3 à $5,2 \%$ com valor médio de $4,1 \%$ para ambos os sistemas de rotação.

A produtividade média de soja na área de rotação soja/milho das propriedades visitadas foi de $2128 \mathrm{~kg} / \mathrm{ha}$, calculada em base às respostas de 9 questionários. Esse valor pode ser considerado satisfatório, comparando-se com a produtividade média do Estado de São Paulo em 1991-1992, que foi de $1834 \mathrm{Kg} / \mathrm{ha}$, segundo anuário estatístico do IBGE. Os agricultores das áreas com rotação soja/cana não tinham dados para informar sobre a produtividade de suas lavouras. Dados referentes à adubação e calagem informados no formulário foram consolidados e são mostrados na Tabela 5 . Nas propriedades com plantio de soja/milho pode-se estimar que $40 \%$ dos agricultores aplicam Zn na adubação da soja no plantio; e que $80 \%$ empregam formulações de adubo com nitrogênio. A dosagem de nitrogênio aplicada é entretanto pequena $(5,4$ a $14,3 \mathrm{~kg} / \mathrm{ha}$ nas formulações que contêm $\mathrm{N}$ ), com média de $8,4 \mathrm{Kg} \mathrm{N} / \mathrm{ha}$. Dentre os agricultores que não aplicam nitrogênio, um deles não inocula, sugerindo acreditar no sucesso de uma nodulação através de rizóbios naturalizados presentes no solo. Apenas um dos agricultores inoculou suas sementes e não aplicou nitrogênio, como seria recomendável.

A média da quantidade de fósforo $\left(\mathrm{P}_{2} \mathrm{O}_{5}\right)$ e potássio $\left(\mathrm{K}_{2} \mathrm{O}\right)$ aplicados nestas propriedades é de 56,1 e $48,9 \mathrm{~kg} / \mathrm{ha}$, respectivamente.

As informações da tabela 5 sugerem que nas propriedades com plantio de soja/cana o zinco $(\mathrm{Zn})$ não é aplicado na adubação. Pode-se observar ainda que $60 \%$ dos agricultores não aplicam nitrogênio (N). Dentre os 4 que inoculam, 3 não aplicam $\mathrm{N}$ e o que aplica o faz numa dose de $14,3 \mathrm{~kg} \mathrm{~N} / \mathrm{ha}$.

Aparentemente há diferenças nas dosagens de nutrientes adicionados com a adubação nas rotações soja/milho com as de soja/cana, visto que as médias das quantidades de nitrogênio $(\mathrm{N})$, fósforo $\left(\mathrm{P}_{2} \mathrm{O}_{5}\right)$ e potássio $\left(\mathrm{K}_{2} \mathrm{O}\right)$ aplicados nestas últimas propriedades são de 3,$9 ; 61,7$ e $65,5 \mathrm{~kg} / \mathrm{ha}$ respectivamente.

Apesar das dosagens das adubações em áreas de cultivo soja/cana aportarem valores de $\mathrm{P}$ e $\mathrm{K}$ mais elevados do que na outra área estudada, a análise química de amostras de solo de ambas as áreas, mostra que os teores de $\mathrm{P}$ e $\mathrm{K}$ no solo da área de rotação soja /cana ( 36,6 e $56 \%$ respectivamente) são inferiores àqueles encontrados na 
área de rotação soja/milho (75,9 e $66 \%$ respectivamente). Esses teores indicam que a cultura da cana extrai mais nutrientes do solo do que o milho; deve-se considerar porém, que o manejo para ambas as culturas é diferente e que a análise de características química do solo revela também o teor residual dos nutrientes anteriormente aplicados no plantio do milho, para os quais não se dispõe de informações.

Na tabela 6 estão tabuladas as respostas à algumas das questões do questionário, referentes ao uso de inoculantes e da adubação na área de ensaio.

Nas lavouras amostradas, $20 \%$ dos agricultores inocularam as sementes. Esse dado contudo, pode não refletir a realidade do uso de inoculantes na região, pois buscou-se deliberadamente escolher áreas onde não fora feita a inoculação, pelo menos no ano da amostragem. Como não foi possível encontrar somente propriedades sem inoculação; respeitando-se os parâmetros previamente definidos (soja IAS-5 em Latossolo Roxo, em rotação com milho ou cana), recorreu-se à 4 propriedades $\left(n^{0} 6,14,16\right.$ e 20), nas quais os agricultores haviam inoculado as sementes de soja naquele ano.

Verifica-se pelos dados mostrados na tabela 6 que $90 \%$ dos agricultores têm conhecimento sobre o inoculante para soja, e que 79\% já o haviam utilizado em outros anos. Porém, em todas as propriedades verificou-se nodulação nas raízes das sojas amostradas, indicando sobrevivência dos rizóbios mesmo que por vários anos não tivessem sido feitas novas inoculações, como no sistema de rotação soja/cana.

A maioria dos entrevistados conserva o inoculante fora da geladeira (93\%). Todos utilizam pelo menos a dose recomendada de inoculante $(250 \mathrm{~g} / 50 \mathrm{Kg}$ de semente) de inoculante misturando-o com água (63\%). Dois agricultores misturam o inoculante puro com as sementes; um o faz sobre uma lona com as mãos e outro em tambor rotativo. Há ainda um agricultor que mistura o inoculante com leite. Entretanto, $67 \%$ dos agricultores entrevistados não acreditam em beneficios da inoculação e somente $50 \%$ verificam a nodulação da lavoura desta leguminosa.

Apesar da boa nodulação encontrada, $36 \%$ dos agricultores aplicaram nitrogênio quando inocularam, em uma dose que variou de 13 a $30 \mathrm{~kg} / \mathrm{alq}$. Esses dados possivelmente refletem a desinformação daqueles agricultores, já que não se recomenda a aplicação de nitrogênio em soja. Aparentemente, a pequena dose de nitrogênio empregada 
pelos agricultores $(8,4$ e $3,9 \mathrm{Kg} / \mathrm{ha}$ em rotação soja/milho e soja/cana respectivamente), não afeta a nodulação da soja; a supressão total da fixação de $\mathrm{N}_{2}$ ocorre em concentrações acima de $600 \mathrm{Kg} \mathrm{N} / \mathrm{ha}$ (WEBER,1966). Convém resaltar que o número de propriedades com rotação soja/cana que utilizam fórmulas com nitrogênio é bem menor do que no sistema soja/milho.

A porcentagem de agricultores que ainda usa nitrogênio nas formulações de adubo parece estar aumentando, pois na década de 70 somente cerca de $10 \%$ deles o utilizavam (informação pessoal do Dr. Dalmo Lasca - CATI-Campinas). Isso pode estar relacionado com insatisfação nos resulstados da inoculação, visto que o inoculante comercial, no geral apresenta problemas de qualidade (LOPES \& KOLLING, 1992). Esses mesmos autores, definem a qualidade dos inoculantes pela eficiência das estirpes de rizóbio utilizadas na sua fabricação e pelo número de células existentes por unidade de peso do produto, e sugerem que seria alcançado um grande avanço na qualidade dos inoculantes se fosse adotada a nível industrial a recomendação para esterilização da turfa por irradiação gama, com 5 Mrads, conforme mostram os resultados de pesquisa de LOPES et alli. (1980). Embora a esterilização da turfa seja recomendada, ela é pouco praticada em nossas condições. A presença de actinomicetos e protozoários em turfa não esterilizada foi detectada por FONSECA et alli. (1985) e as estirpes resistentes à estreptomicina empregadas nesse inoculante sobreviveram por mais tempo, em relação às sensíveis.

Todos os entrevistados responderam que não utilizam o inoculante para outras leguminosas e 35\% informaram fazer observações da nodulação dessas lavouras. Esses dados são justificados pelo fato de no Estado de São Paulo, a soja ser praticamente a única leguminosa cultivada para a qual existe uma consciência de necessidade de inoculação (LOPES \& GIARDINI, 1981). 
Tabela 5. Dados de fórmulas, dosagens de adubos e calcário, teores de nutrientes utilizados nas propriedades amostradas observados

\begin{tabular}{|c|c|c|c|c|c|c|}
\hline \multirow{2}{*}{$\begin{array}{l}\mathrm{No}^{\circ} \mathrm{da} \\
\text { propriedade }\end{array}$} & \multicolumn{2}{|l|}{ Adubo NPK } & \multicolumn{3}{|c|}{ Quantidade de } & \multirow[t]{2}{*}{ Calagem } \\
\hline & fórmula & dose & $\mathrm{N}$ & $\mathbf{P}$ & $\mathbf{K}$ & \\
\hline & --.--- \% ----- & -..--..- & -.-... & ha -... & -.-- & -.-- \\
\hline \multicolumn{7}{|c|}{ A -Rotação soja/milho } \\
\hline 1 & $03-15-15+Z n$ & 312,5 & 9,4 & 46,9 & 46,9 & 0 \\
\hline 2 & $04-20-20$ & 321,4 & 12,9 & 64,3 & 64,3 & 0 \\
\hline 3 & $03-16-16$ & 290,2 & 8,7 & 46,4 & 46,4 & 0 \\
\hline 4 & $00-18-06$ & 223,0 & 0 & 40,1 & 13,4 & 1800 \\
\hline 5 & $04-20-20$ & 357,0 & 14,3 & 71,4 & 71,4 & 2700 \\
\hline 6 & $00-20-10$ & 357,0 & 0 & 71,4 & 35,7 & 900 \\
\hline 7 & $03-15-15+\mathrm{Zn}$ & 357,0 & 10,7 & 53,5 & 53,5 & 1800 \\
\hline 8 & $02-20-15+\mathrm{FTE}+\mathrm{Mg}$ & 268,0 & 5,4 & 53,6 & 40,2 & 0 \\
\hline 9 & $03-15-15+\mathrm{Zn}$ & 357,0 & 10,7 & 53,5 & 53,5 & 2000 \\
\hline 10 & $03-15-15+\mathrm{Zn}$ & 402,0 & 12,1 & 60,3 & 60,3 & 2700 \\
\hline Média & & 324,5 & 8,4 & 56,1 & 48,6 & 1190 \\
\hline \multicolumn{7}{|c|}{ B -Rotação soja/cana } \\
\hline 11 & $02-20-20$ & 357,0 & 7,1 & 71,4 & 71,4 & 0 \\
\hline 12 & $02-20-20$ & 312,5 & 6,3 & 62,5 & 62,5 & 0 \\
\hline 13 & $00-20-20$ & 268,0 & 0 & 53,6 & 53,6 & 2200 \\
\hline 14 & $00-12-20$ & 491,1 & 0 & 58,9 & 98,2 & 3100 \\
\hline 15 & $00-20-20$ & 268,0 & 0 & 53,6 & 56,3 & 2230 \\
\hline 16 & $00-20-20$ & 357,0 & 0 & 71,4 & 71,4 & 0 \\
\hline 17 & $04-20-20$ & 290,0 & 11,6 & 58,0 & 58,0 & 0 \\
\hline 18 & $00-20-20$ & 357,0 & 0 & 71,4 & 71,4 & 1800 \\
\hline 19 & $00-20-20$ & 223,0 & 0 & 44,6 & 44,6 & 2230 \\
\hline 20 & $04-20-20$ & 357,0 & 14,3 & 71,4 & 71,4 & 2230 \\
\hline Média & & 328,1 & 3,9 & 61,7 & 65,6 & 1379 \\
\hline
\end{tabular}


TABELA 6. Avaliação das respostas às questões sobre adubação e inoculação da área amostrada.

\begin{tabular}{|c|c|c|c|}
\hline \multirow[t]{2}{*}{ Perguntas } & \multirow{2}{*}{$\begin{array}{l}N^{\circ} \text { de questionário } \\
\text { com resposta }\end{array}$} & \multicolumn{2}{|c|}{$\%$ de respostas } \\
\hline & & positivas & negativas \\
\hline Usou inoculante na lavoura amostrada? & 20 & 20 & 80 \\
\hline Já usou inoculante em outros anos? & 19 & 79 & 21 \\
\hline Conhece o inoculante? & 19 & 90 & 10 \\
\hline Preserva o inoculante na geladeira? & 14 & 7 & 93 \\
\hline Inocula como recomendado? ${ }^{*}$ & 8 & 100 & 0 \\
\hline Mistura o inoculante com água? & 8 & 63 & 37 \\
\hline A inoculação dá resultado ? & 15 & 33 & 67 \\
\hline Avalia nodulação na lavoura da soja ? & 18 & 50 & 50 \\
\hline Usa nitrogênio quando inocula? & 11 & 36 & 64 \\
\hline Já inoculou em outras leguminosas? & 19 & 0 & 100 \\
\hline Avalia nodulação em outras leguminosas? & 17 & 35 & 65 \\
\hline
\end{tabular}

* Utiliza pelo menos $250 \mathrm{~g}$ de inoculante/ $50 \mathrm{Kg}$ de semente, misturando em água e homogeneizando.

\subsection{Isolamento de rizóbios}

Foram isoladas 99 culturas (44 de área de cultivo soja/milho e 47 de área de cultivo soja/cana) através de maceramento dos nódulos, segundo a técnica proposta por SOMASEGARAM \& HOBEN (1985). Essas culturas, foram catalogadas e integradas à coleção de Rhizobium spp e Bradyrhizobium spp da Seção de Microbiologia do Solo (SMS) do Instituto Agronômico de Campinas. A tabela 7 mostra o número de culturas obtidas de cada uma das 20 propriedades e o número SMS de identificą̧ão das mesmas, para referências futuras. 
Tabela 7. Total de estirpes de rizóbios isoladas de soja em diferentes propriedades em dois sistemas de cultivo, e número das estirpes na coleção de Rhizobium spp e Bradyrhizobium spp do Instituto Agronômico de Campinas.

\begin{tabular}{|c|c|c|}
\hline $\begin{array}{l}\text { Número da } \\
\text { propriedade }\end{array}$ & $\begin{array}{l}\text { Estirpe de Rizóbio } \\
\qquad\left(\mathrm{N}^{0} \mathrm{SMS}\right)\end{array}$ & $\begin{array}{l}\text { Total de } \\
\text { estirpes }\end{array}$ \\
\hline \multicolumn{3}{|c|}{ A- Rotação soja/milho } \\
\hline 1 & $789,790,791,792,793,794,795$ & 7 \\
\hline 2 & $799,800,801$ e 802 & 4 \\
\hline 3 & $805,809,810,811$ e 813 & 5 \\
\hline 4 & $814,815,816,817,818$ e 819 & 6 \\
\hline 5 & 822,823 e 824 & 3 \\
\hline 6 & $825,826,827,828$ e 829 & 5 \\
\hline 7 & $830,831,832,833,834,835,836$ e 837 & 8 \\
\hline 8 & 839,842 e 843 & 3 \\
\hline 9 & $844,848,849$ e 850 & 4 \\
\hline 10 & 852 , e 855 & 2 \\
\hline \multicolumn{3}{|c|}{ B- Rotação soja/cana } \\
\hline 11 & $856,858,859,860$ e 861 & 5 \\
\hline 12 & $862,863,864,865$ e 866 & 5 \\
\hline 13 & $867,868,869,870,871$ e 872 & 6 \\
\hline 14 & $875,876,878,880,882,884,885$ & 7 \\
\hline 15 & 890 & 1 \\
\hline 16 & $892,893,894$ & 3 \\
\hline 17 & $896,897,899,901$ e 902 & 5 \\
\hline 18 & $904,905,906$ e 908 & 4 \\
\hline 19 & 909,910 e 913 & 3 \\
\hline 20 & $914,915,916,917$ e 919 & 5 \\
\hline Total & & 91 \\
\hline
\end{tabular}




\subsection{Teste de nodulação}

De 99 culturas avaliadas, 91 formaram nódulos na soja IAC-8. Na figura 1, tem-se uma vista geral do teste de nodulação. O desenvolvimento normal da soja no controle com nitrogênio mostrou que a solução nutritiva estava satisfatória para as avaliações que se pretendia efetuar; a ausência de nódulos nos tratamentos, sem inoculação e o consequente amarelecimento das plantas, mostrou que o manuseio e a assepsia durante a inoculação e condução foram satisfatórios (figura 2).

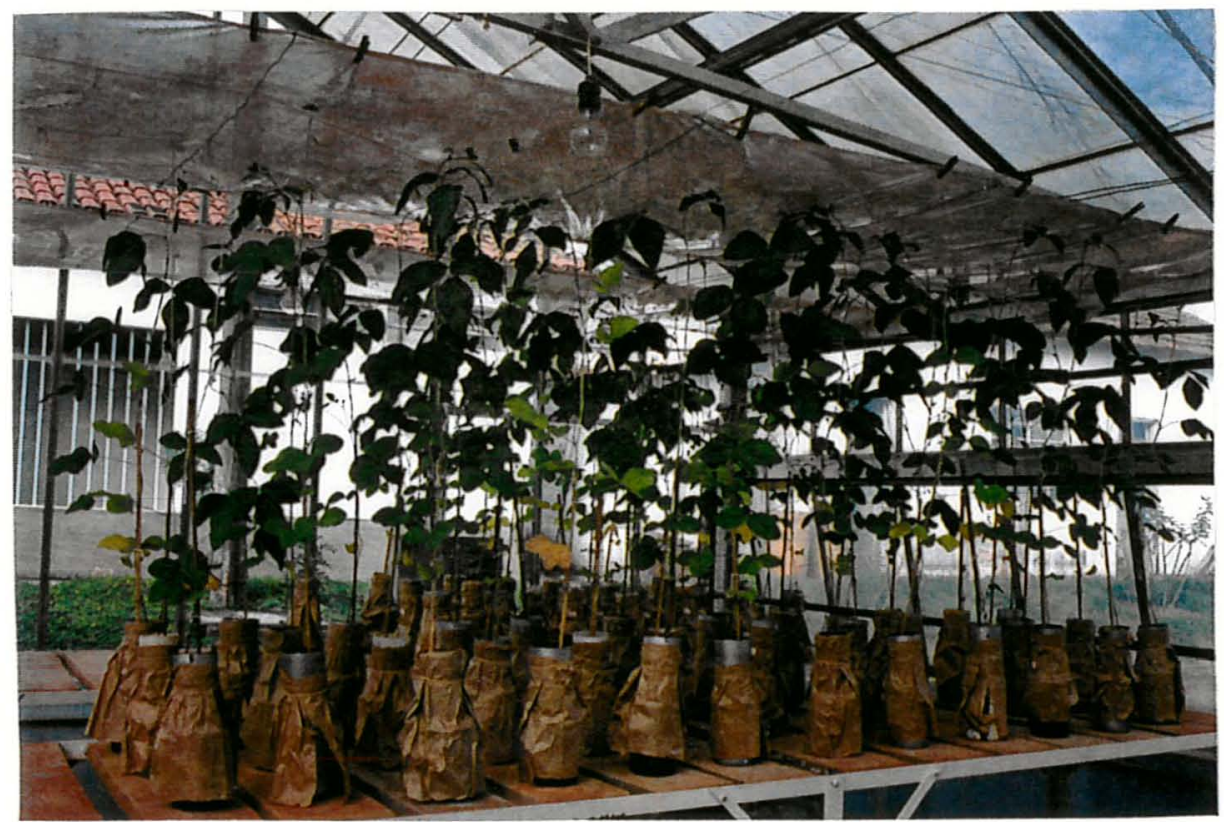

Figura 1: Vista geral de teste de nodulação em casa de vegetação, em vaso de Leonard com solução nutritiva. Plantas aos 46 dias após o plantio. 


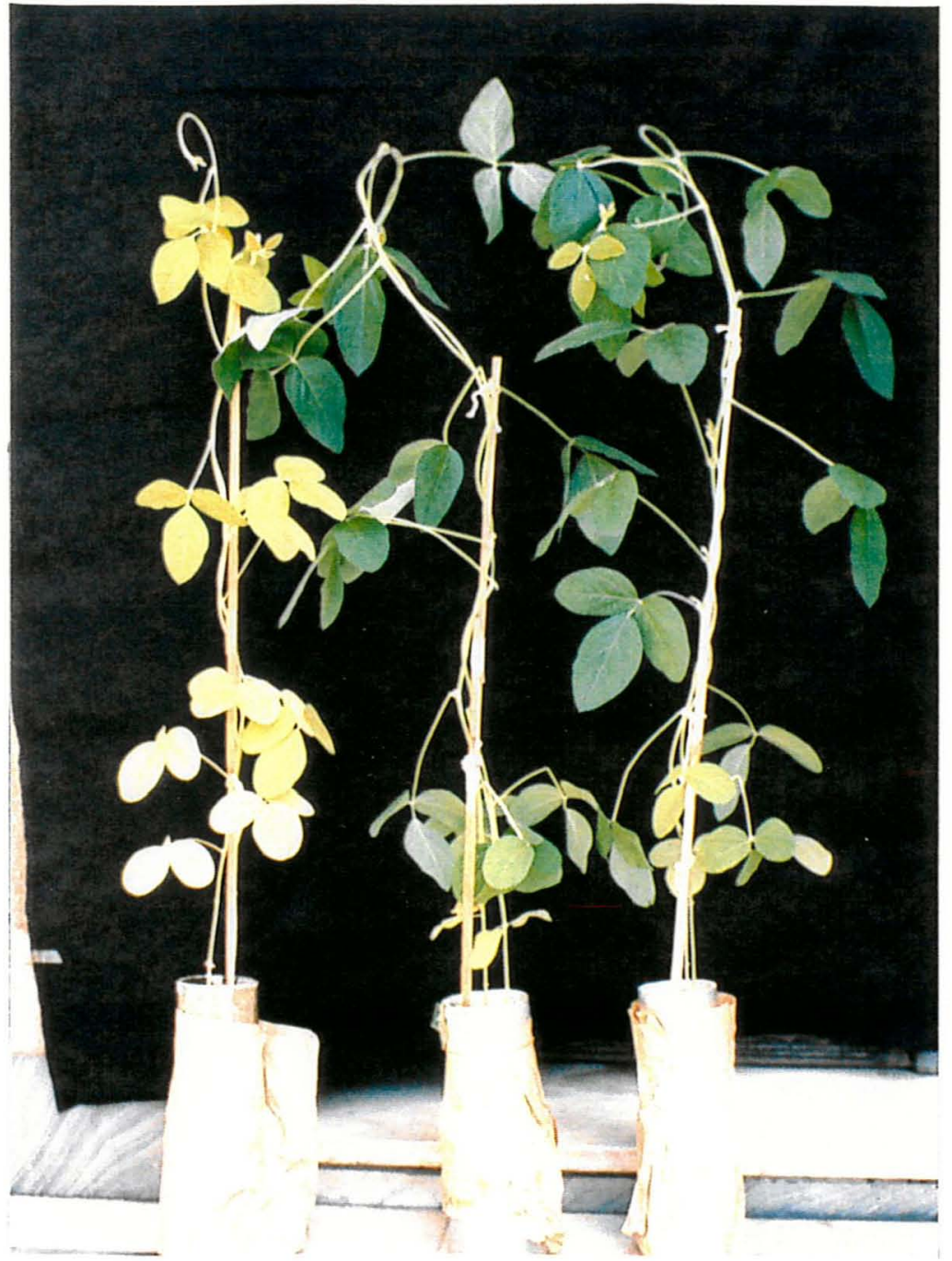

Figura 2: Da esquerda para a direita, vasos de Leonard com os tratamentos controle, SMS-799 (estirpe eficiênte) e controle mais nitrogênio. 


\subsection{Caracterização das culturas puras}

\subsubsection{Teste de aglutinação com soro hiperimune anticélulas inteiras}

Das 91 culturas puras, submetidas ao teste de aglutinação com soros hiperimunes produzidos com células inteiras de rizóbios, apenas 21 puderam ser devidamente caracterizadas pois não apresentaram reação cruzada. Dessas estirpes, duas são pertencentes aos sorogrupos IV, onze ao VI e oito ao IX. Reações cruzadas foram observadas em 41 culturas com os AS-CI SEMIA 5052,587 e 5019; 29 culturas não apresentaram reação com nenhum soro hiperimune empregado (vide fluxograma em apêndice 6.1). Três dos oito soros hiperimunes testados, (SEMIA 5025, 5080 e 5032), não reagiram com nenhuma das culturas.

DATE \& DECKER (1965) e LEMOS (1994), trabalhando com soros produzidos contra células inteiras de $B$. japonicum também verificaram reação cruzada entre várias estirpes. DATE \& DECKER (1965) sugeriram que as estirpes de um mesmo grupo de reatividade poderiam compartilhar determinantes antigênicos comuns que as levariam a apresentar as reações cruzadas por eles observadas.

\subsubsection{Teste de aglutinação com soros hiperimunes anti-LPS (AS-LPS)}

As culturas que apresentaram reação cruzada no teste de aglutinação com soros hiperimunes de células inteiras, foram submetidas a teste com soros hiperimunes preparados com lipopolissacarídeos (LPS) de estirpes dos sorogrupos: I (SEMIA 5052), II (SEMIA 5025), III (SEMIA 587), IV (SEMIA 5019) e VIII ( SEMIA 5061).

Das 41 culturas, 25 reagiram com somente um dos soros hiperimunes, sendo que 3 foram classificadas no sorogrupo VIII, 17 no sorogrupo $I V, 4$ no sorogrupo III e 1 no sorogrupo I. As 16 culturas restantes não reagiram com nenhum dos AS-LPS testados. Nenhuma cultura apresentou reação com AS-LPS do sorogrupo II (apêndice 6.1.)

Os soros hiperimunes preparados com LPS demonstraram ser ferramentas importantes para a caracterização de estirpes em nódulos ou em culturas puras, visto que 
25 estirpes que haviam antes apresentado reação cruzada, puderam ser diferenciadas por utilização deste tipo de soro hiperimune.

Afim de se obter soros hiperimunes mais específicos, alguns pesquisadores (OLSEN et al 1983; e CARARETO \& LEMOS,1995) têm utilizado procedimentos de adsorção de soros, produção de soros monoclonais e utilização de constituintes celulares (por exemplo LPS) que possam se caracterizar como determinantes antigênicos indutores de soros monoespecíficos. MURRAY et alli (1990) e CARROFF et al (1990) consideram os LPSs como os principais determinantes antigênicos de bactérias gram negativas, e sugerem sua utilização na obtenção de soros monoespecíficos, devido a atividade antigênica dessas moléculas.

\subsubsection{Eletroforese de LPS em SDS-PAGE:}

As culturas puras que não apresentaram nenhuma reação em teste de aglutinação com soros hiperimunes produzidos com células inteiras das estirpes de referência ou LPS , foram avaliadas por eletroforese de LPS em SDS-PAGE. Os perfis das moléculas de LPS obtidos por eletroforese (figura 3) comparados aos das estirpes padrão de rizóbios de diferentes sorogrupos (figura 4) permitiram uma eficiente identificação de 45 culturas puras.

Das 45 culturas puras testadas, vinte e cinco apresentaram perfil eletroforético semelhantes ao do sorogrupo I, dez ao do III, oito ao IV e duas ao VIII (vide fluxograma no apêndice 6.1). As tabelas 8 e 9 mostram o número de culturas puras por sorogrupo identificadas por teste de aglutinação ou eletroforese em SDS-PAGE, e o número de isolados identificados por propriedade, respectivamente para áreas de rotação soja/milho $\mathrm{e}$ soja/cana. Enquanto que a tabela 10 apresenta a distribuição porcentual do total de culturas puras isoladas de soja, por sorogrupos, na área amostrada em sistema de rotação soja/milho e soja/cana e média desses dois sistemas de rotação.

Verificou-se que as estirpes do sorogrupo IV (SEMIA5019) e I (SEMIA 5052) predominaram nos cultivos de soja/milho (17) e soja/cana (18), respectivamente; esses valores expressos em porcentagem correspondem, à $36 \%$ e $41 \%$. Em média as estirpes do sorogrupo VIII (SEMIA 5061) foram as de menor ocorrência. No geral, em ordem 
decrescente, as médias de ocorrência foram: sorogrupos IV $(29,6 \%)$; I $(28,6 \%)$; III $(15,4 \%)$; VI $(12,1 \%)$; VIII $(5,5 \%)$ e IX $(8,8 \%)$.

TABELA 8. Caracterização sorológica de culturas puras de rizóbios isoladas de áreas com rotação soja/mitho: número de estirpes por sorogrupo e propriedade.

\begin{tabular}{|c|c|c|c|c|c|c|c|}
\hline \multirow[t]{2}{*}{ Propriedade (1) } & \multicolumn{6}{|c|}{ Sorogrupos (2) } & \multirow{2}{*}{$\begin{array}{l}\text { Total de } \\
\text { cultura }\end{array}$} \\
\hline & I & III & IV & VI & VIII & $\mathrm{LX}$ & \\
\hline & \multicolumn{6}{|c|}{ 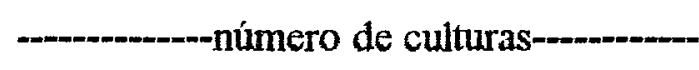 } & \\
\hline 1 & - & 1 & 5 & - & 1 & - & 7 \\
\hline 2 & 2 & - & 1 & - & - & 1 & 4 \\
\hline 3 & - & 1 & 2 & - & - & 2 & 5 \\
\hline 4 & 1 & 2 & 2 & - & 1 & - & 6 \\
\hline 5 & - & 3 & - & - & - & - & 3 \\
\hline 6 & 3 & - & - & - & - & 2 & 5 \\
\hline 7 & 2 & 2 & 3 & - & 1 & - & 8 \\
\hline 8 & - & - & 2 & - & 1 & - & 3 \\
\hline 9 & - & - & - & 3 & - & 1 & 4 \\
\hline 10 & - & - & 2 & - & - & - & 2 \\
\hline Total & 8 & 9 & 17 & 3 & 4 & 6 & 47 \\
\hline
\end{tabular}

(1) O nome e a localizaçăo das propriedades estão na Tabela 1.

(2) Número de catálogo (SEMLA) das estirpes antigenos utilizadas na definição do sorogrupo: 5052 (I), 587 (III), IV (5019), 566 (V), 5061 (VIII) e 518 (IX).

A análise do padrão eletroforético em SDS-PAGE do LPS da parede celular das estirpes estudadas mostrou ser um parâmetro importante para a caracterização biológica de estirpes de rizóbios. A heterogeneidade dos constituintes proteícos, polissacarídicos e enzimáticos de célula bacterianas, determinada por eletroforese em gel de poliacrilamida, permite maior discriminação entre isolados, mostrando diferenças entre estirpes pertencentes ao mesmo sorogrupo (NOEL \& BRILL, 1980). Essa técnica também tem 
sido empregada com sucesso, para estudos sobre diversidade, dinâmica da população e comparação entre isolados de uma mesma espécie ou entre diferentes espécies (NOEL \& BRILL, 1980; FUQUAY et al., 1984; KAMICKER \& BRILL, 1986 e ARAÚJO et al., 1994).

TABELA 9. Caracterização sorológica de culturas puras de rizóbios isoladas de áreas com rotação soja/cana: número de estirpes por sorogrupo e propriedade

\begin{tabular}{|c|c|c|c|c|c|c|c|}
\hline \multirow{2}{*}{ Propriedades (1) } & \multicolumn{6}{|c|}{ Sorogrupos (2) } & \multirow[t]{2}{*}{ Total de Culturas } \\
\hline & I & III & IV & $\mathrm{VI}$ & VIII & IX & \\
\hline & --- & & nero & cultu & as-- & & \\
\hline 11 & 4 & - & - & 1 & - & - & 5 \\
\hline 12 & - & 2 & 2 & 1 & - & - & 5 \\
\hline 13 & 1 & - & 2 & 3 & - & - & 6 \\
\hline 14 & 2 & 3 & - & 2 & - & - & 7 \\
\hline 15 & 1 & - & - & - & - & - & 1 \\
\hline 16 & 1 & - & 2 & - & - & - & 3 \\
\hline 17 & 3 & - & 1 & - & - & 1 & 5 \\
\hline 18 & 1 & - & 2 & - & - & 1 & 4 \\
\hline 19 & 2 & - & - & - & 1 & - & 3 \\
\hline 20 & 3 & - & 1 & 1 & - & - & 5 \\
\hline Total & 18 & 5 & 10 & 8 & 1 & 2 & 44 \\
\hline
\end{tabular}

(1) O nome e a localização das propriedades estão na tabela 1.

(2) Número de catálogo (SEMIA) das estirpes antígenos utilizadas na definição do sorogrupo: 5052 (I), 587 (III), IV (5019), VI (566), VIII (5061) e IX (518). 
Tabela 10. Distribuição percentual do total de culturas puras isoladas da soja, por sorogrupos, na área amostrada em sistema de rotação soja/milho e soja/cana e média desses dois sistemas de rotação.

\begin{tabular}{lcccccc}
\hline $\begin{array}{l}\text { Sistema } \\
\text { de }\end{array}$ & \multicolumn{5}{c}{ Sorogrupos (1) } \\
Rotação & I & III & IV & VI & VIII & IX \\
\hline soja/milho & 17,0 & 19,1 & 36,2 & 6,4 & 8,5 & 12,8 \\
soja/cana & 40,9 & 11,4 & 22,7 & 18,2 & 2,3 & 4,5 \\
\hline Média & 28,6 & 15,4 & 29,6 & 12,1 & 5,5 & 8,8 \\
\hline
\end{tabular}

(1) Número de catálogo (SEMLA) das estirpes antigenos utilizadas na definição do sorogrupo: 5052 (D), 587 (III), 5019 (IV), 566 (VI), 5061 (VII) e 518 (IX). 


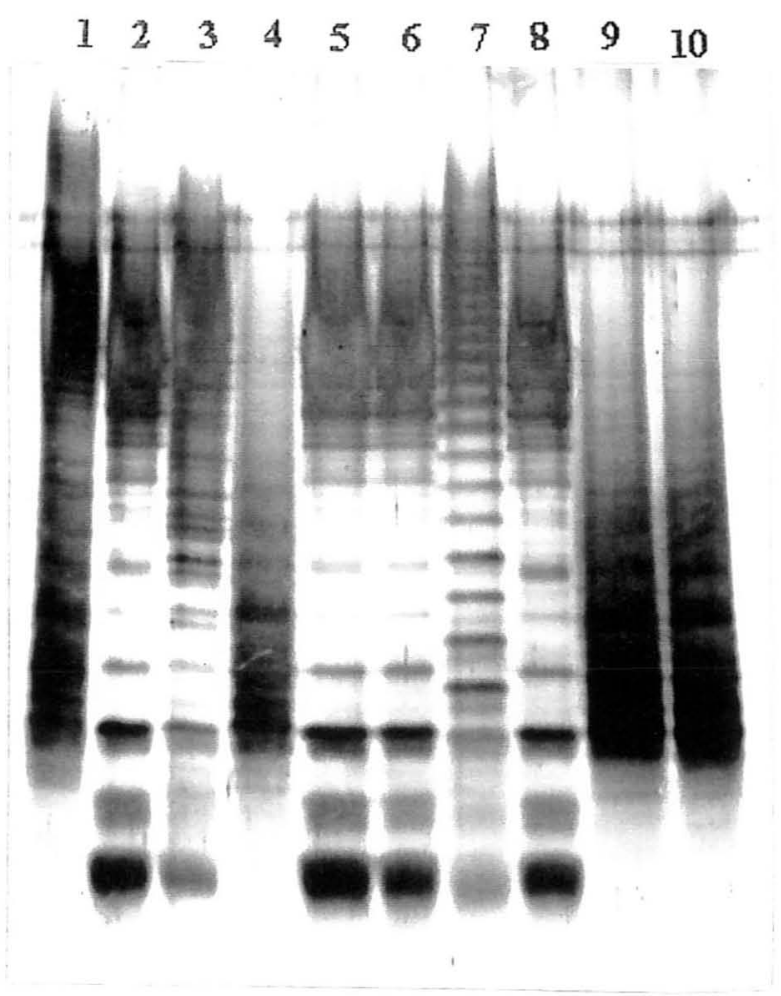

Figura 3. Perfil eletroforético em SDS-PAGE de lipopolissacarídeos extraidos de isolados de soja IAS-5, em 20 propriedades na região amostrada sobre Latossolo Roxo. Canaletas $1,4,9$ e 10 estirpes do sorogrupo I = SEMIA $5052 ; 2,5,6$ e 8 estirpes do sorogrupo III= SEMIA 587; 3 e 7 estirpes do sorogrupo IV = SEMIA 5019. 


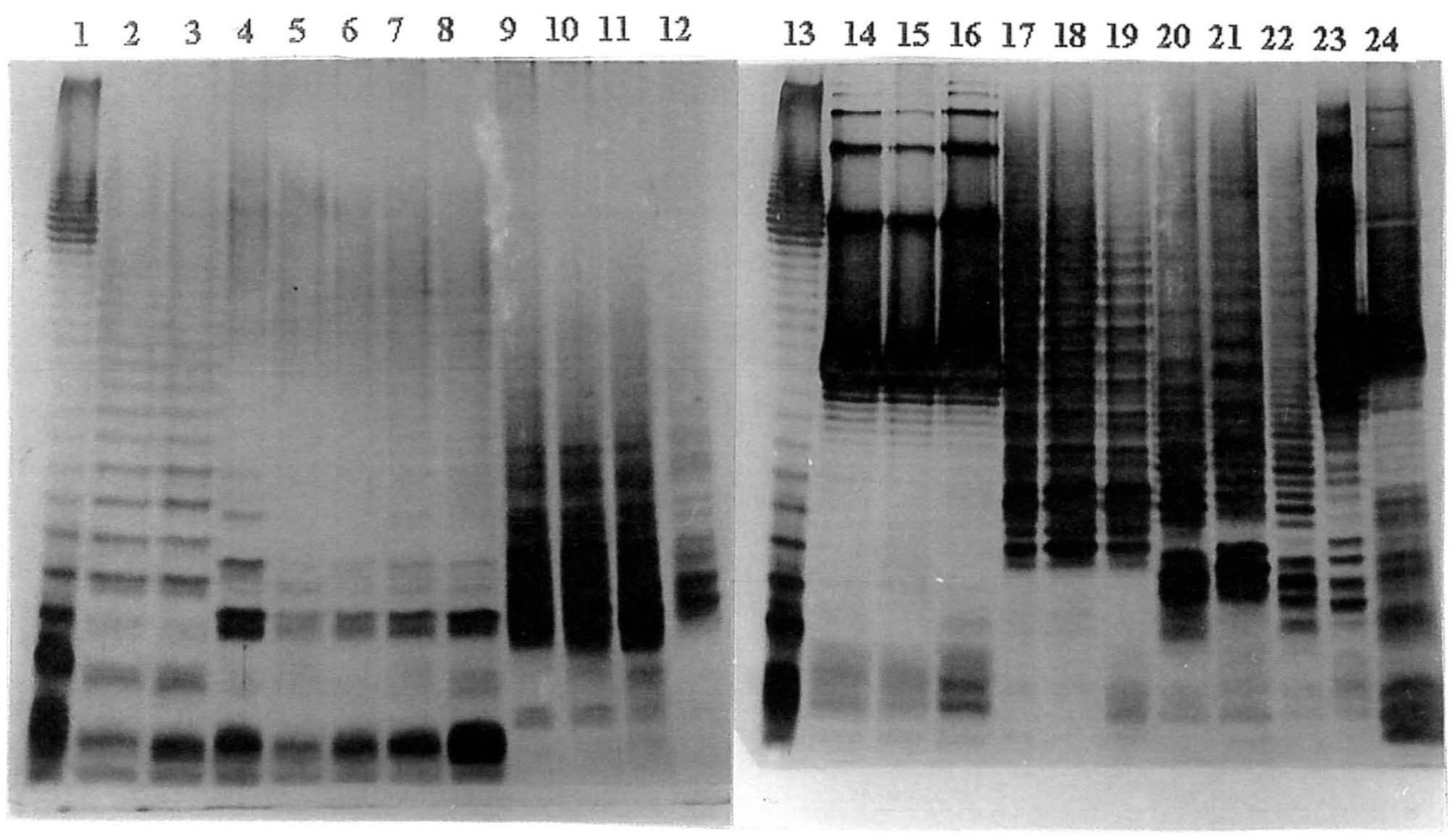

Figura 4. Perfil eletroforético em SDS-PAGE de lipopolissacarídeos de estirpes referenciais de Bradyrhizobium japonicum. Canaletas: 1- LPS padrão de Escherichia coli; 2- SEMIA 5019; 3- SEMIA 5001; 4- SEMIA 5061; 5- SEMIA 5013; 6- SEMIA 5018; 7- SEMIA 587; 8- SEMIA 5002; 9- SEMIIA 5052; 10- SEMIA 509; 11- SEMIA 5039; 12- SEMIA 5000; 13- LPS padrão E.coli; 14- SEMIA 586; 15- SEMIA 5080; 16SEMIA 5021; 17- SEMIA 566; 18- SEMIA 5079; 19- SEMIA 511; 20- SEMIA 5073; 21- SEMIA 5020; 22- SEMIIA 5032; 23- SEMIA 5025 e 24- SEMIA 518.

(Cortesia da Profa. Dra. Eliana Lemos) 


\subsection{Teste preliminar de eficiência}

Como a condução do teste de nodulação foi satisfatória, pode-se pressupor que o resultado do desenvolvimento das plantas inoculadas e noduladas, em cada vaso, estava relacionado com a eficiência da estirpe inoculada naquele vaso.

Visto que foram feitos quatro testes de nodulação em diferentes épocas, calculouse a eficiência relativa de cada cultura pura, em cada um deles, em relação à cultura padrão SEMIA 587, que havia sido incluida nos quatro testes, viabilizando-se, assim, a comparação estatística conjunta dos dados (vide apêndice 5 para observação dos dados referentes a cada cultura e testes).

A eficiência relativa foi calculada com a relação porcentual do valor médio da matéria seca da parte aérea (MSPA) das estirpes isoladas em relação à média de MSPA da estirpe SEMIA 587. Cabe lembrar que duas das estirpes atualmente recomendadas para produção de inoculantes, SEMLA 587 e SEMLA 5019, foram usadas como padrão. Nos quatro testes a estirpe SEMIA 587 apresentou maior valor médio de MSPA (apêndice 5) e por isso foi usada para esses cáculos.

O número de estirpes eficientes de cada propriedade foi um outro parâmetro empregado para avaliar preliminarmente a eficiência de fixação das comunidades de rizóbios naturalizados. Para fim de análise estatística e tendo em vista a natureza preliminar do teste de eficiência, considerou-se estirpes eficientes as que apresentaram eficiência relativa com valor pelo menos maior do que $90 \%$ do da estirpes padrão SEMIA 587.

As tabelas 11 e 12 mostram os valores médios e extremos, obtidos para número e peso de nódulos secos e peso de matéria seca da parte aérea; além do número de estirpes de rizóbios, eficiência relativa e número de estirpes eficientes, por propriedade para os sitemas de cultivo soja/milho e soja/cana respectivamente. 
Tabela 11. Número de estirpes de rizóbios isoladas de soja cultivada em área com rotação soja/milho, valores médios de número e peso seco de nódulos e matéria seca da parte aérea de soja cultivada em vasos de Leonard e inoculada com essas estirpes, eficiência relativa às estirpes padrão e número de estirpes eficientes por propriedade. Plantas colhidas com 50-54 dias após o plantio.

\begin{tabular}{|c|c|c|c|c|c|c|c|}
\hline \multirow{2}{*}{$\begin{array}{l}\text { número da } \\
\text { propriedade }\end{array}$} & \multirow{2}{*}{$\begin{array}{l}\text { número do } \\
\text { isolados } \\
\text { testados }\end{array}$} & \multicolumn{2}{|c|}{ nódulo } & \multirow{2}{*}{$\begin{array}{l}\text { MSPA } \\
\text { g/pl }\end{array}$} & \multirow{2}{*}{$\begin{array}{l}\text { Eficiênci: } \\
\text { Relativa }\end{array}$} & \multirow{2}{*}{\multicolumn{2}{|c|}{$\begin{array}{r}\text { Número } \\
\text { estirpes } \\
\text { eficientes }\end{array}$}} \\
\hline & & $\mathrm{n}^{0} / \mathrm{pl}$ & $\mathrm{mg} / \mathrm{pl}$ & & & & \\
\hline 1 & 7 & $38-183(81)$ & $380-853(607)$ & $3,9-7,5(5,0)$ & 79 & $a b c$ & 1 \\
\hline 2 & 4 & $90-121(105)$ & $431-1302(879)$ & $4,1-7,4(5,9)$ & 93 & $\mathbf{a}$ & 3 \\
\hline 3 & 5 & $69-121(105)$ & $566-800(703)$ & $2,9-5,9(4,8)$ & 75 & abcd & 1 \\
\hline 4 & 6 & $66-135(91)$ & $586-1105(781)$ & $5,0-7,2(5,9)$ & 93 & $\mathbf{a}$ & 4 \\
\hline 5 & 3 & $22-207(103)$ & $322-775(588)$ & $3,1-5,4(4,5)$ & & abc & 1 \\
\hline 6 & 5 & $97-168(142)$ & $330-647(438)$ & $2,9-4,7(3,3)$ & 63 & bcd & 0 \\
\hline 7 & 8 & $43-178(92)$ & $333-1081(612)$ & $2,2-6,5(4,9)$ & $87^{*}$ & $a b$ & 4 \\
\hline 8 & 3 & $98-192(143)$ & $480-774(649)$ & $3,1-5,2(4,4)$ & 84 & $\mathbf{a b}$ & 2 \\
\hline 9 & 4 & $76-115(93)$ & $369-645(524)$ & $3,0-5,1(4,1)$ & & abcd & 0 \\
\hline 10 & 2 & $117-125(121)$ & $600-681(641)$ & $4,0-4,7(4,3)$ & $77^{*}$ & & 0 \\
\hline Total & 47 & & & & & & 16 \\
\hline
\end{tabular}

Padrão**

$587 / 1$

$587 / 2$

70

444

6,36

$587 / 3$

86

420

5,26

$587 / 4$

82

316

6,13

46

313

2,19

\footnotetext{
* Médias com valores de pelo menos 2 testes de nodulação/eficiência

** O número após a barra( () indica o número do teste de nodulação/preliminar eficiência

C. $\mathrm{V}=22,34 \%$

() entre parênteses, média dos valores
} 
A análise estatística revelou que as estirpes das propriedades $6,17,18$ e 19 foram significativamente menos eficientes que as demais. Nenhuma estirpe isolada dessas propriedades foi considerada eficiente, pelo critério acima citado. Os valores encontrados para a baixa eficiência relativa dessas estirpes não podem ser explicados pelas diferenças das características de manejo nem pela análise química do solo das diferentes propriedades. Verificou-se que 4 propriedades ( $n^{0 s} 3,9,16$ e 20) não diferiram significativamente das propriedades de menor ER e nem das de maior ER, apesar das grandes diferenças e valor absoluto.

As propriedades de $n^{0} 2$ e 4 (rotação soja/milho) foram as que mais se destacaram quanto a ER. Sendo que nesta primeira propriedade três entre quatro estirpes testadas foram eficientes, duas delas (SMS- 799 e SMS-802) sendo inclusive superiores quanto a ER da estirpe padrão. Para a propriedade 4, dentre seis estirpes testadas quatro foram eficientes (SMS-814,816,818 e 819).

A comunidade de rizóbios do solo, mostrou-se portanto composta de estirpes com diferenças significativas na capacidade de fixar nitrogênio. A maioria dos isolados apresentaram-se inferiores, quanto a eficiência de fixação de $\mathrm{N}_{2}$, quando comparados à estirpe padrão SEMIA 587 (apêndice 5). VINCENT (1954) e JONES et al.(1978), observaram uma comunidade de rizóbios ineficientes na fixação. Estes últimos autores, sugerem que quando uma população de rizóbios é ineficiente pode-se esperar uma resposta à inoculação. Em um experimento conduzido em área de rotação soja/cana em São Joaquim da Barra-SP, não foi constatada diferença significativa na resposta à inoculação com as estirpe SEMIA- 587 e 5019 em doses de até $10^{10}$ rizóbios/g (LIMA, 1995).

Dentre as propriedades de onde foram testados 5 ou mais isolados, as de número 4 e 7 foram as que apresentaram maior número de isolados eficientes. Três propriedades da rotação soja/milho $\left(\mathrm{n}^{0} \mathrm{~s} 6,9\right.$ e 10$)$ não apresentaram nenhum isolado considerado eficiente.

Os valores médios de eficiência relativa obtidos por propriedade foram sempre inferiores à $93 \%$, porém nenhum dos valores observados foi inferior aqueles encontrados para os controle sem nitrogênio de cada teste de nodulação, como era esperado (esses valores só poderiam ser inferiores ao controle se as estirpes fossem parasitas). 
Tabela 12. Número de estirpes de rizóbios isoladas de soja cultivada em área com rotação soja/cana, valores médios de número e peso de nódulos secos e matéria seca da parte aérea de soja cultivada em vasos de Leonard e inoculada com essas estirpes, eficiência relativa às estirpes padrão e número de estirpes eficientes por propriedade. Plantas colhidas com 50-54 dias após o plantio.

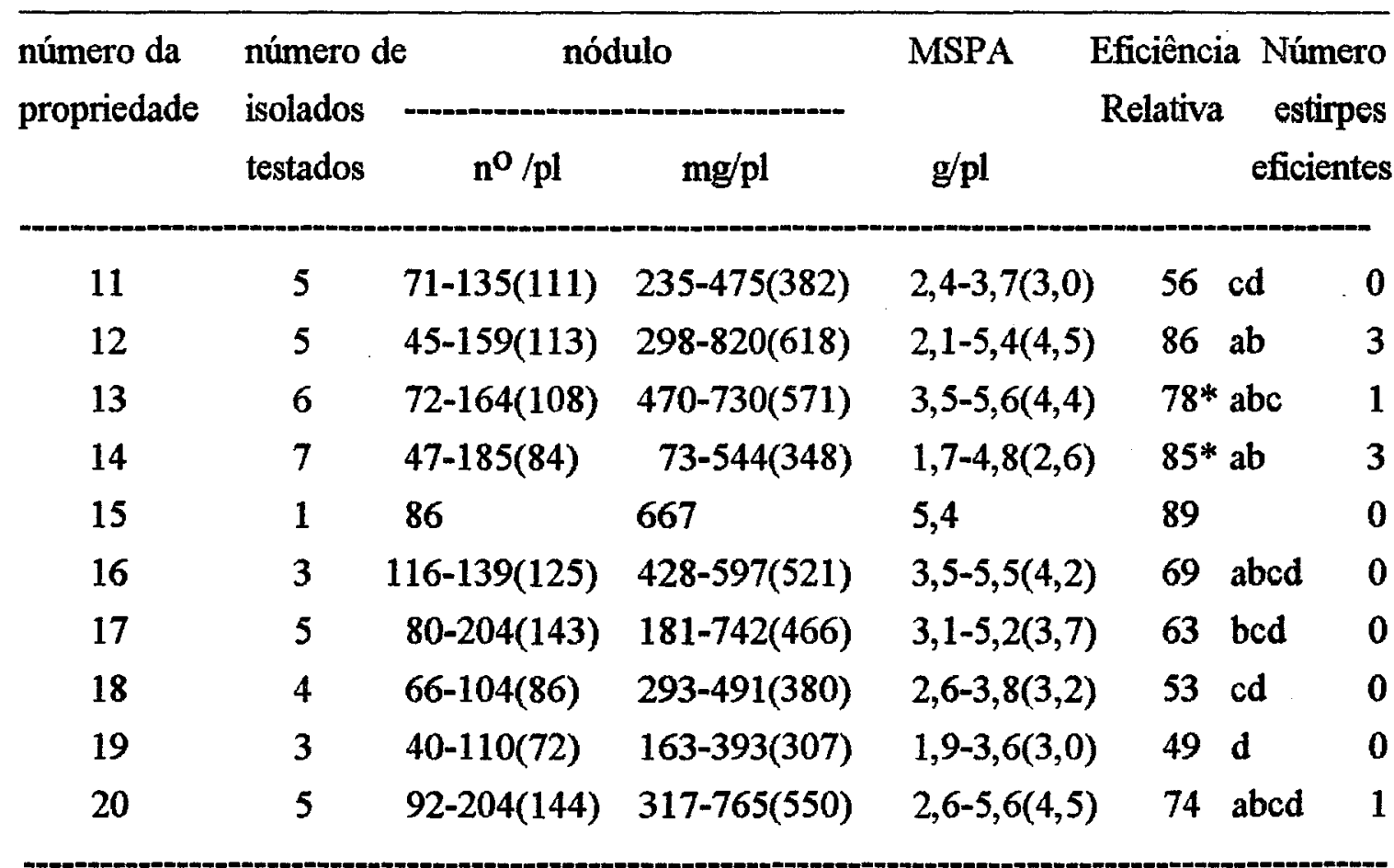

Subtotal

Padrão**

$587 / 1$

$587 / 2$

$587 / 3$

$587 / 4$

$\begin{array}{lll}70 & 444 & 6,36 \\ 86 & 420 & 5,26 \\ 82 & 316 & 6,13 \\ 46 & 313 & 2,19\end{array}$

* Médias com valores de pelo menos 2 testes de nodulação/eficiência

** O número após a barra $(/)$ indica o número do teste de nodulação/preliminar eficiência

C.V. $=22,34 \%$

() entre parênteses, média dos valores

Médias seguidas da mesma letra não diferem pelo teste de Dunkan (5\%) 
Dentre as propriedades com rotação soja/cana, as de número 12 e 14 foram as que apresentaram maior número de estirpes eficientes, proporcionalmente ao número de isolados. Seis propriedades (as de $n^{0} 11,15,16,17,18$ e 19) não apresentaram nenhum isolado considerado eficiente.

Constatou-se grande variabilidade em termos de peso de matéria seca da parte aérea em relação ao número e peso de nódulos secos. As menores médias do número e do peso de nódulos secos, foram observadas nas propriedades 1 e 6 , respectivamente. Enquanto que as maiores médias para esses mesmos parâmetros, na sequencia, ocorreram nas propriedades 8 e 2 . A significância do número e peso de nódulos como indicador eficiente da fixação do nitrogênio por estirpes de rizóbios tem sido bastante controvertida (VIDOR et al. 1979). Atualmente, acredita-se que o peso de nódulos secos esteja mais correlacionado com a eficiência das estirpes nos nódulos do que o número (CARDOSO, E.J.B.N., comunicação pessoal).

Alguns estudos mostraram bons coeficientes de correlação entre número de nódulos e peso de matéria seca ou rendimento de grãos (DOBEREINER et al., $1966 \mathrm{e}$ 1970), enquanto outros (THOMPSON et al., 1974) demostraram baixas correlações. O baixo ajustamento dessas funções poderia ser explicado como possíveis compensações em aumento do peso de nódulo para um baixo número de nódulos ou à diferenças entre cultivares quanto ao número de sítios de infeç̧ão por unidade de raiz, quando diferentes cultivares estivessem sendo estudados (VIDOR et al. 1979).

A planta hospedeira compensa o baixo número de nódulos formados, quando o rizóbio no solo está em baixa concentração, pelo aumento do tamanho dos nódulos; sendo que nódulos de soja podem aumentar mais de 200 vezes o seu tamanho quando o número de nódulos eficientes no sistema radicular é reduzido. Portanto, o tecido nodular viável à fixação de nitrogênio não tem sido considerado uma função linear do número de rizóbios no solo.

A tabela 13 apresenta as médias de ER de 91 isolados por sistema de rotação e propriedade. Verificou-se que a média da ER dos isolados de nódulos coletados sob cultivo soja/milho (80\%) foi maior e estatisticamente diferente do que aqueles isolados de nódulos coletados sob cultivo soja/cana (71\%). É possível que o manejo empregado na 
cultura da cana, bem como a ausência da planta hospedeira por periodos de 4-6 anos possam acarretar mutações nas estirpes do solo, levando-as a uma menor eficiência.

HUNGRIA et al.(1994), verificaram que os rizóbios isolados de solos onde a soja vinha sendo cultivada, há algum tempo eram mais eficientes e apresentavam características morfológicas, fisiológicas e genéticas diferentes daquelas isoladas do solo com sucessão exclusiva de gramíneas.

A diferença das médias de ER dos isolados por propriedade para cada sistema de rotação, foi significativa. Dentre as propriedades com rotação soja/milho as de número $2 \mathrm{e}$ 4 foram as que apresentaram maior ER; para a rotação soja/cana, as de número 12 e 14 foram superiores para esse mesmo parâmetro.

No apêndice 6.2. observa-se que a maioria dos isolados das propriedades sobre cultivo de rotação soja com milho, apresentam ER maior do que 75\%. Nas propriedades em cultivo com rotação de soja com cana, os isolados de somente 4 propriedades apresentaram ER superior à 75\%. Observa-se também, que neste último sistema de cultivo o número de propriedades sem estirpes eficientes foi maior do que para o cultivo de rotação soja com milho.

As 91 culturas devidamente caracterizadas (item 4.4) foram reavaliadas quanto a eficiência relativa. Considerou-se o conjunto de dados de eficiência relativa para as culturas de um mesmo sorogrupo como repetições de um mesmo tratamento; isso possibilitou efetuar uma análise estatística para a eficiência relativa por sorogrupos, e reagrupar os outros resultados obtidos em casa de vegetação (número e peso de nódulos secos, peso da matéria seca da parte aérea, e número e porcentagem de estirpes eficientes) da mesma forma.

Os valores médios obtidos para o reagrupamentpo por sorogrupos são apresentados na tabela 14. Verificou-se pela tabela 14 que a diferença entre a média de ER de isolados de sorogrupos distintos foi significativa. Na amostra conjunta dos dois sistemas de rotação, as estirpes do sorogrupo IX apresentaram uma média de eficiência relativa significativamente menor que todas as demais. As dos sorogrupos I e VI foram significativamente inferiores às do sorogrupo III que se destacou das demais. 
A tabela 15 apresenta os dados de média da ER dos isolados por sorogrupo pelo sistema de rotação. Quando se fez a separação dos sorogrupos por sistema de rotação verificou-se que na rotação soja/milho, o sorogrupo $\mathrm{XX}$ apresentou média significativamente menor que quatro sorogrupos.

Os isolados do sorogrupo III se destacaram pela melhor eficiência, em ambos os sistemas de rotação, sendo que em rotação soja/cana a média da ER foi de $97 \%$, significativamente maior que a dos demais sorogrupos (tabela 14). A média da ER dos isolados dos sorogrupos I e $\mathrm{IV}$, da rotação soja/milho (83 e $82 \%$ respectivamente) não diferiram da do sorogrupo III, enquanto que na rotação soja/cana as médias (68 e 66\% respectivamente) para esses mesmos sorogrupos foram significativamente inferiores à do sorogruopo III. Isso, sugere aparentemente, que em rotação soja/cana, a comunidade de rizóbios no solo desses dois últimos sorogrupos citados, poderia ter perdido sua capacidade de fixar o $\mathrm{N}_{2}$, em relação às bactérias do sorogrupo III.

Quando se compara os dados de eficiência por grupos sorológicos (tabela 15) com os da análise por propriedades (tabela 13), verifica-se, curiosamente, que aparentemente um maior conjunto de estirpes eficientes aparecia na rotação soja/milho. Isso sugere que para uma melhor informação dos efeitos da rotação na população de rizóbios, a caracterização adequada das estirpes é de fundamental importância. Entretanto, para as estirpes eficientes do sorogrupo III, isoladas em rotação soja/cana (SMS- 864, 865, 882 e 884) a média da ER foi de $98,5 \%$, e para as de rotação soja/milho foi de $105 \%$.

As médias de número e peso de nódulos secos por sorogrupos apresentaram-se variáveis; os menores valores para esses parâmetros ocorreram nos sorogrupos VII e IX; e os maiores valores nos sorogrupos IX e III, na sequência. $O$ que sugere que os nódulos do sorogrupo IX, apesar de abundantes são menores do que os dos outros sorogrupos.

As estirpes (caracterizadas no item 4.4) reagrupadas por sorogrupo, que apresentaram eficiência relativa maior do que $90 \%$ (estirpes eficientes), foram as seguintes:

-sorogrupo I: SMS- 800, 802, 835, 872 e 885

-sorogrupo III: SMS- 790, 818, 819, 823, 834, 864, 865, 882 e 884

-sorogrupo IV: SMS- 799, 805, 814, 830, 833, 843 e 864 
-sorogrupo VI: SMS- 919

-sorogrupo VII: SMS-816 e 839

-sorogrupo IX: nenhuma estirpe deste sorogrupo foi considerada eficiente

Dentre essas estirpes, dezesseis (34\%) são provenientes de nódulos coletados em área de cultivo soja/milho e oito (18\%) de soja/cana; todas elas são de interesse para experimentos futuros, que deverão ser desenvolvidos.

Tabela 13. Média de eficiência relativa por propriedade para estirpes de rizóbios isoladas de soja cultivada em área de rotação soja/milho e soja/cana. Experimento realizado em casa de vegetação em vasos de Leonard.

\begin{tabular}{cccccc}
\hline \multicolumn{3}{c}{ Soja / Milho } & \multicolumn{4}{c}{ Soja / Cana } \\
No propriedade & ER (\%) & No & propriedade & ER (\%) \\
\hline 2 & 93 & a & 12 & 86 & a \\
\hline 4 & 93 & a & 14 & 85 & a \\
\hline 7 & 87 & ab & 13 & 78 & ab \\
\hline 8 & 84 & ab & 20 & 74 & abc \\
1 & 79 & ab & 16 & 69 & abc \\
\hline 5 & 77 & ab & 17 & 63 & abc \\
3 & 75 & ab & 11 & 56 & bc \\
9 & 69 & ab & 18 & 53 & c \\
6 & 63 & b & 19 & 49 & c \\
\hline 6 & 80 & A & & 71 & B \\
\hline Média & & & & & \\
\hline
\end{tabular}

C.V. Soja/Milho : $21,64 \%$

C.V. Soja/Cana : $23,15 \%$

C.V. Média entre as rotações : $24,79 \%$

Médias seguidas da mesma letra, minúsculas na coluna e maiuscula na linha não diferem, pelo teste Dunkan (5\%). 
Tabela 14. Valores extremos e médias de matéria seca da parte aérea, número, peso de nódulos secos, número e porcentagem de estirpes eficientes e eficiência relativa de 91 isolados por sorogrupo. Plantas com 50-54 DAP,cultivadas em vasos de Leonard com solução nutritiva isenta de Nitrogênio.CV.IAC-8.

\begin{tabular}{|c|c|c|c|c|c|c|c|}
\hline \multirow[t]{2}{*}{ Sorogrupos } & \multirow{2}{*}{$\begin{array}{l}\text { número de } \\
\text { isolados } \\
\text { testados }\end{array}$} & \multicolumn{2}{|c|}{ nódulo } & \multirow{2}{*}{$\begin{array}{c}\text { MSPA } \\
\text { g/pl }\end{array}$} & \multirow{2}{*}{$\begin{array}{c}\text { Eficiência } \\
\text { Relativa } \\
\%\end{array}$} & \multicolumn{2}{|c|}{$\begin{array}{l}\text { Estirpes } \\
\text { eficientes }\end{array}$} \\
\hline & & $\mathrm{n} \% \mathrm{pl}$ & $\mathrm{mg} / \mathrm{pl}$ & & & $n^{\circ}$ & $\%$ \\
\hline I & 26 & $40-204(104)$ & $163-1302(546)$ & $1,9-7,4(4,2)$ & $73 \mathrm{~b}$ & 5 & 19 \\
\hline III & 14 & $44-207(92)$ & $321-1105(653)$ & $1,9-7,5(4,8)$ & ) $92 a$ & 9 & 64 \\
\hline IV & 27 & $43-192(98)$ & $181-968(592)$ & $2,1-6,5(4,5)$ & i) $76 a b$ & 7 & 26 \\
\hline VI & 11 & $47-159(106)$ & $73-765(489)$ & $1,7-5,6(4,0)$ & ) $73 b$ & 1 & 9 \\
\hline VIIII & 5 & $38-110(76)$ & $393-811(625)$ & $3,5-6,4(4,9)$ & ) $80 a b$ & 2 & 40 \\
\hline IX & 8 & $66-204(113)$ & $317-800(501)$ & $2,6-4,8(3,4)$ & ) 57 & 0 & 0 \\
\hline
\end{tabular}

() Entre parênteses, média dos valores ; C.V. Eficiência Relativa : $23,36 \%$

Tabela 15. Média de eficiência relativa por sorogrupo, para estirpes de rizóbios isoladas de soja para os sistemas de rotação soja/milho e soja/cana. Experimento realizado em casa de vegetação, em vasos de Leonard.

\begin{tabular}{|c|c|c|c|c|}
\hline \multirow[b]{2}{*}{ Sorogrupo } & \multicolumn{3}{|c|}{ Sistema de Rotação } & \\
\hline & Soja & / Milho & Soja / C & \\
\hline & & (\%) & & (\%) \\
\hline III & (9) & $89 a$ & (5) & $97 \mathrm{a}$ \\
\hline VIII & (4) & $86 a$ & & NA \\
\hline I & (9) & $83 \mathrm{a}$ & (18) & $68 \mathrm{~b}$ \\
\hline IV & (17) & $82 \mathrm{a}$ & (10) & $66 \mathrm{~b}$ \\
\hline VI & (3) & $70 a b$ & (8) & $75 \mathrm{~b}$ \\
\hline $\mathbf{X X}$ & (6) & $60 \mathrm{~b}$ & & NA \\
\hline
\end{tabular}

C.V. Soja/Milho : $20,70 \%$; C.V. Soja/Cana : $23,93 \%$

() Entre parênteses, total de estirpes 


\subsection{Caracterização das estirpes nos nódulos}

Para melhor definir a ocorrência das estirpes nos sistemas de rotação soja/milho e soja/cana, foram testados 800 nódulos, provenientes de plantas coletadas nas propriedades amostradas, sendo 400 de cada sistema de rotação; foram testados 40 nódulos de cada propriedade.

As estirpes presentes nas suspensões obtidas por maceramento dos nódulos, foram submetidos a teste de "imunodot" com soros hiperimunes das estirpes SEMIA5052,SEMIA-587,SEMIA-5019 e SEMIA-566 correspondentes aos sorogrupos I, III, IV e VI, respectivamente.

As tabelas 16 e 17 (soja/milho e soja/cana respectivamente) apresentam o número e porcentagem de nódulos por propriedade que reagiram com os 4 soros hiperimunes testados. A tabela 18 mostra a distribuição porcentual de 800 nódulos,por sorogrupos, nas áreas amostradas.

Apesar das estirpes do sorogrupo IV (SEMIA 5019), terem apresentado baixa ocupação nodular em área de cultivo soja/cana (4,2\%), VIDOR et al.(1979), em estudo de capacidade de competição por sítio de infecção nodular entre seis estirpes de rizóbios em nove cultivares de soja, em experimento conduzido em casa de vegetação, em areia e solução nutritiva observaram que essa mesma estirpe (SEMIA $5019=29 \mathrm{~W}$ ) foi altamente competitiva por sítio de infecção nodular, dominando amplamente as outras estirpes em todas as cultivares de soja estudadas. Em cinco cultivares de soja a porcentagem de nódulos formados por essa estirpe foi igual ou superior a 98\%. Porém CALDWELL (1969), observou a campo, que a estirpe SEMIA-5032 (110) formava 76\% dos nódulos quando utilizada em mistura com a estirpe SEMIA 5019, mostrando menor competitividade dessa última estirpe.

Pela observação da tabela 17, verifica-se que as estirpes do sorogrupo III (SEMIA587) apresentaram baixa colonização principalmente em área de cultivo soja/cana (3,2\%); mas esta mesmas estirpes evidenciaram alta capacidade competitiva em experimento a campo com baixa população de rizóbios (FREIRE et al. 1976 citado por VIDOR et al. 1979). Observa-se ainda que as estirpes relacionadas ao sorogrupo VI. (SEMIA 566) 
apresentaram baixa ocupação nodular para ambos os sistemas de rotação $(4,7$ e $1,5 \%$ para áreas de cultivo soja/milho e soja/cana, respectivamente).

Tabela 16. Número de reações positivas observadas pelo teste de "ïmmunodot" com 4 soros hiperimunes em suspensão de nódulos coletados em propriedades com rotação soja/milho, e porcentagem de culturas de cada soro hiperimune, por propriedade.

\begin{tabular}{cccccc}
\hline No da propriedade & \multicolumn{5}{c}{ Soro hiperimune $(1)$} \\
& I & III & IV & VI & NI \\
\hline 1 & $3(7,5)$ & $3(7,5)$ & $17(42,5)$ & 0 & $17(42,5)$ \\
2 & $11(27,5)$ & $4(10)$ & $12(30)$ & 0 & $13(32,5)$ \\
3 & $15(37,5)$ & $1(2,5)$ & $14(35)$ & 0 & $10(25)$ \\
4 & $17(42,5)$ & $5(12,5)$ & $9(22,5)$ & 0 & $9(22,5)$ \\
5 & $8(20)$ & $8(20)$ & $1(2,5)$ & 0 & $23(57,5)$ \\
6 & $2(5)$ & $12(30)$ & $10(25)$ & $3(7,5)$ & $13(32,5)$ \\
7 & $6(15)$ & $7(17,5)$ & $4(10)$ & $1(2,5)$ & $22(55)$ \\
8 & $1(2,5)$ & $18(45)$ & $5(12,5)$ & 0 & $16(40)$ \\
9 & $9(22,5)$ & $2(5)$ & $9(22,5)$ & $10(25)$ & $10(25)$ \\
10 & $6(15)$ & 0 & $6(15)$ & $5(12,5)$ & $23(57,5)$ \\
\hline Total(Média) & $78(19,5)$ & $60(15)$ & $87(21,7)$ & $19(4,7)$ & $156(39)$ \\
\hline$---\cdots-\cdots$ & & & & \\
\hline
\end{tabular}

(1) entre parênteses porcentagens por propriedade; $\mathrm{NI}=$ não identificado.

FREIRE et al. (1976) citado por VIDOR et al. (1979), também observaram baixa ocorrência da estirpe SEMIA-566 a campo. Em outro experimento realizado, durante seis anos em Guaíba-RS, em solo sem população estabelecida de rizóbios, a estirpe SEMIA 566 mostrou baixa ocupação nodular logo no primeiro ano após a inoculação, enquanto que outras cinco estirpes testadas (SEMIA-509,527,523c,586 e 587) demonstraram boa infectividade, sendo recuperadas na maioria dos nódulos das plantas onde foram inoculadas. Neste mesmo experimento a estirpe SEMIA-587 demonstrou ser altamente competitiva. Entretanto, a sua capacidade de competir por sítios de infeç̧ão nodular 
diminuiu com a sucessão de cultivos, o que revelou uma necessidade de efetuar a inoculação das sementes em todos os plantios (FREIRE et al., 1983).

Tabela 17. Número de reações positivas observadas pelo teste de "ïmmunodot" com 4 soros hiperimunes em suspensão de nódulos coletados em propriedades com rotação soja/cana, e porcentagem de culturas de cada soro hiperimune, por propriedade.

\begin{tabular}{|c|c|c|c|c|c|}
\hline \multirow[t]{2}{*}{$N^{\circ}$ da propriedade } & \multicolumn{5}{|c|}{ Soro hiperimune ${ }^{(1)}$} \\
\hline & I & III & IV & VI & NI \\
\hline 11 & $18(45)$ & $2(5)$ & $3(7,5)$ & 0 & $17(42,5)$ \\
\hline 12 & $11(27,5)$ & $1(2,5)$ & 0 & 0 & $28(70)$ \\
\hline 13 & $18(45)$ & 0 & 0 & 0 & $22(55)$ \\
\hline 14 & $11(27,5)$ & 0 & 0 & $2(5)$ & $27(67,5)$ \\
\hline 15 & $4(10)$ & 0 & $3(7,5)$ & $2(5)$ & $31(77,5)$ \\
\hline 16 & $3(7,5)$ & 0 & $5(12,5)$ & 0 & $32(80)$ \\
\hline 17 & $16(40)$ & 0 & $2(5)$ & 0 & $22(55)$ \\
\hline 18 & $1(2,5)$ & $2(5)$ & $3(7,5)$ & $1(2,5)$ & $33(82,5)$ \\
\hline 19 & $13(32,5)$ & $3(7,5)$ & $1(2,5)$ & $1(2,5)$ & $22(55)$ \\
\hline 20 & 0 & $5(12,5)$ & 0 & 0 & $35(87,5))$ \\
\hline Total(Média) & $95(23,7)$ & $13(3,2)$ & $17(4,2)$ & $6(1,5)$ & $269(67,2)$ \\
\hline
\end{tabular}

(1) entre parênteses porcentagens por propriedade; $\mathrm{NI}=$ não identifacado.

Maior recuperação das estirpes isoladas não significa necessariamente efeitos positivos sobre o crescimento da soja (KAPUSTA \& ROUWENHORST, 1973; BOONKERD et al., 1978), sendo entretanto de fundamental importância que as estirpes de maior ocorrência nos nódulos sejam eficientes, afim de se atingir plenamente os objetivos do suprimento nitrogenado via simbiose. Convém observar que a estirpe de maior ocorrência em áreas de cultivo soja/cana, SEMIA-5052, apresentou uma média de ER no teste de nodulação/preliminar eficiência de somente $73 \%$ (tabela 14 item 4.5 ); 
consequentemente, a maior porcentagenm de nódulos infectados por esta estirpe pode implicar em diminuição de nitrogênio fixado e rendimento de grãos de soja.

Tabela 18 . Distribuição porcentual das estirpes dos 800 nódulos, por sorogrupos, nas áreas amostradas em sistema de rotação soja/milho e soja/cana e médias desses 2 sistemas de rotação.

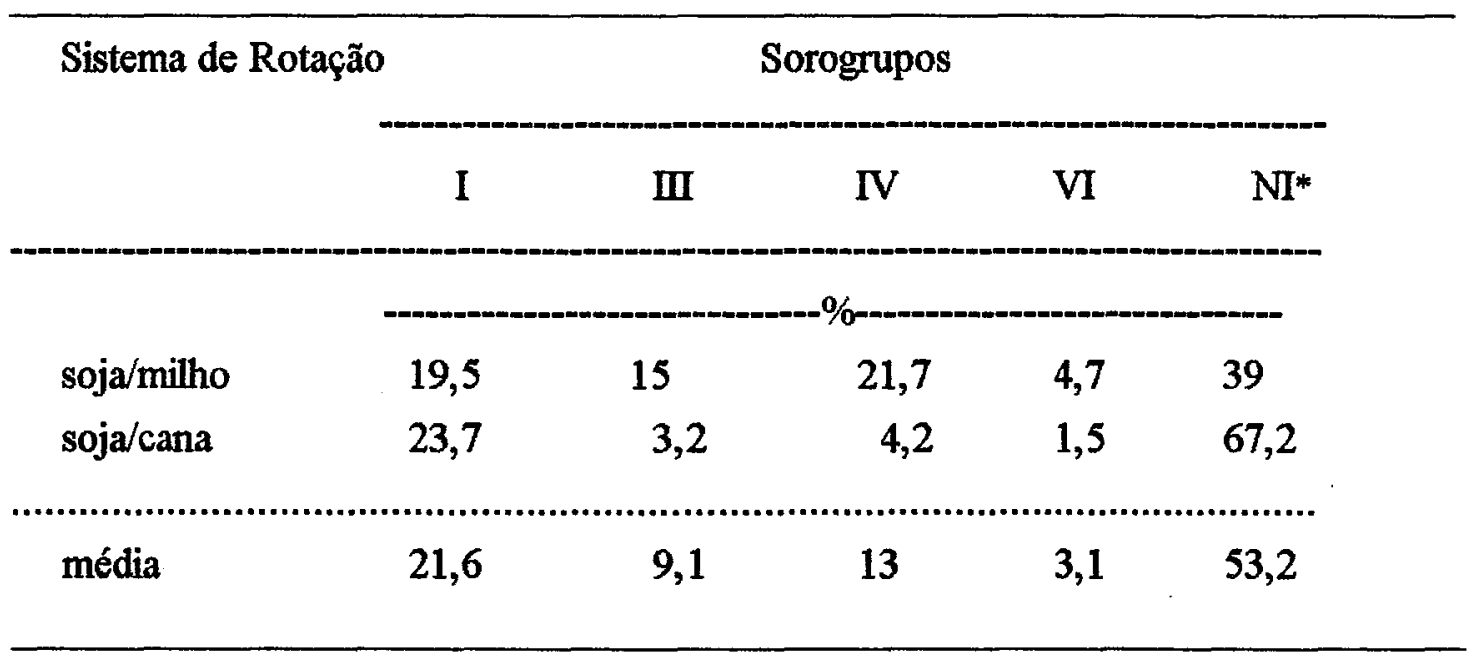

As suspensões de alguns nódulos apresentaram reação positiva com mais de um soro hiperimune. Isso sugere homologia entre pelo menos um dos determinantes antigênicos dos bacteróides das estirpes que formaram esses nódulos com os do antígeno padrão do sorogrupo. Existe ainda a possibilidade da presença de mais de uma estirpe no nódulo, ocasionando o fenômeno da infecção multipla (LINDEMAN, 1974 e SKRDLETA \& KARIMOVA, 1969; citados por VIDOR, 1979) aumentando desse modo, a diversidade de reação.

Dentre as quatro propriedades ( $n^{0} s$ 6,14,16 e 20) as quais os agricultores informaram ter inoculado as sementes de soja no ano de amostragem, duas ( $\mathrm{n}^{0} \mathrm{~s} 14$ e 16) não apresentaram nódulos com reação contra o soro hiperimune SEMIA 587, e duas ( $n^{0} \mathrm{~s}$ 14 e 20), não apresentaram nódulos com reação contra o soro hiperimune SEMIA 5019.

Diversas pesquisas têm demonstrado o baixo efeito da inoculação da soja em solos contendo uma população estabelecida de rizóbios. Assim, JOHNSON et al. (1965) observaram que apenas $5 \%$ dos nódulos eram formados pelas estirpes introduzidas pela inoculação em solos com comunidade estabelecida de rizóbios. Inúmeros fatores podem 
levar a baixa colonização do solo pelas estirpes recomendadas, mesmo que procedendo-se a inoculação das plantas no ano agrícola das mesmas. Segundo FREIRE \& VIDOR (1981) a nodulação pelas estirpes recomendadas somente estaria garantida se estas alcançassem uma colonização de 3.000 células de rizóbios/grama de solo seco. AMAGER \& LOBREAU (1982), também mencionaram a importância da quantidade de rizóbios no solo como fator capaz de influenciar o processo de nodulação.

Cabe lembrar que a má qualidade de inoculantes, e a manutenção inadequada do mesmo pelos agricultores, também podem levar a baixa ocupação nodular das estirpes recomendadas. LOPES (1975/76), considerou que as deficiências na qualidade do inoculante teriam três possiveis origens: a fábrica, o revendedor ou o agricultor; e sugeriu que as maiores deficiências de qualidade nos inoculantes comercializados em São Paulo sejam devidas às condições de armazenamento, transporte e manuseio e que seria interessante que todas as partidas de inoculantes saídas da fábrica pudessem passar pelo sistema de controle, o que aliás ocorre na Austrália e no Uruguai, onde o prazo de validade é estabelecido pelos laboratórios de controle, em função do número de rizóbios viáveis no inóculo recém-fabricado. Mais recentemente, LOPES \& KOLLING (1992) sugeriram que a baixa qualidade dos inoculantes comerciais está relacionada com o emprego de suporte (turfa) não esterilizado.

Ainda para as áreas inoculadas, somente nas amostras de nódulos da propriedade de número 6 , sobre rotação soja/milho, é que as porcentagens obtidas para reação com soros hiperimunes 587 e 5019 ( 30 e $25 \%$ respectivamente) foram superiores às dos outros soros hiperimunes testados. TRIPLETT et al (1993) já havia observado que os rizóbios são muito persistentes no solo, e que a comunidade desta bactéria não era muito afetada em rotação de soja com milho.

A tabela 19 mostra o número de culturas por sorogrupos, identificadas por meio de testes de "immunodot", eletroforese e aglutinação.

Verifica-se pela tabela 19 que as suspensões de nódulos ou de culturas puras foram identificadas na sua maioria (22\%) como pertencentes ao sorogrupo I, sendo que as restantes pertencem aos sorogrupos IV (15\%); III (10\%); VI $(4,0 \%)$; IX $(0,9 \%)$ e VII $(0,6 \%)$. 
Tabela 19. Número de identificações realizadas por sorogrupos, em suspensões de nódulos ("immunodot"); e nas culturas puras (aglutinação com soro hiperimune produzido com células inteiras ou lipopolissacarídeos, e eletroforese).

\begin{tabular}{lcccccccc}
\hline Tipo de teste (1) & \multicolumn{7}{c}{ Soros hiperimunes (2) } \\
& I & III & IV & VI & VIII & IX & N(3) \\
\hline "immunodot" (800) & 173 & 73 & 104 & 25 & - & - & 425 \\
& & & & & & & \\
AG-células inteiras (91) & - & - & 2 & 11 & - & 8 & $(70)$ \\
AG- LPS (41) & 1 & 4 & 17 & - & 3 & - & $(16)$ \\
Eletroforese de LPS (45) & 25 & 10 & 8 & - & 2 & - & 0 \\
\hline Total & 199 & 87 & 131 & 36 & 5 & 8 & 425 \\
Porcentagem & 22 & 10 & 15 & 4 & 0,6 & 0,9 & 47,5
\end{tabular}

(1) Antígenos usados como padrão dos sorogrupos: I = SEMLA 5052; III = SEMIA 587; IV = SEMLA 5019; VI = SEMIA 566; VIII = SEMIA 5061 e IX = SEMIA 518. Esses dois últimos sorogrupos não foram utilizados em teste de "immunodot".

(2) AG-células inteiras e AG- LPS significam teste de aglutinação com soro hiperimune produzido com células inteiras e com lipopolissacarideos,respectivamente.

(3) $\mathrm{NI}=$ não identificado

() Culturas identificadas por outro teste.

A tabela 20 indica o número de suspensões de nódulos (bacteróides), e de culturas puras por sorogrupo para cada sistema de rotação.

A somatória da caracterização de isolados e bacteróides pode aumentar o número de bactérias estudadas, possibilitanto o cálculo de novas médias de ocorrência dos sorogrupos para os diferentes sistemas de rotação estudados. A tabela 21 apresenta a distribuição porcentual de 891 (bacteróides + culturas puras) bactérias, por sorogrupos, nas áreas amostradas em sistema de rotação soja/milho e soja/cana e médias desses dois sistemas de rotação. 
Tabela 20. Número de suspensões de nódulos, identificadas por "immunodot" e culturas puras identificadas por aglutinação ou eletroforese.

\begin{tabular}{lllllll}
\hline $\begin{array}{l}\text { Sistema de } \\
\text { rotação }\end{array}$ & \multicolumn{4}{c}{ Sorogrupos (1) } & & NI(2) \\
& I & III & IV & VI & VIII & IX
\end{tabular}

A. "immunodot"

soja/milho $(400)^{(3)}$

soja/cana (400)

$\begin{array}{lllllll}78 & 60 & 87 & 19 & \text { NA } & \text { NA } & 156\end{array}$

$\begin{array}{lllllll}95 & 13 & 17 & 6 & \text { NA } & \text { NA } & 269\end{array}$

B.aglutinação/eletroforese

soja/milho (47)

soja/cana (44)

$\begin{array}{rrrrrrr}8 & 9 & 17 & 3 & 4 & 6 & - \\ 18 & 5 & 10 & 8 & 1 & 2 & -\end{array}$

Total

199

$87 \quad 131$

$\begin{array}{lll}36 & 5 & 8\end{array}$

425

(1) Antígenos usados como padrão dos sorogrupos: I = SEMIA 5052; III = SEMIA 587; IV = SEMLA 5019; VI = SEMLA 566; VIII = SEMIA 5061 e IX = SEMIA 518. Esses dois últimos sorogrupos não foram utilizados em teste de "immunodot" (NA = não avaliado).

(2) NI = não identificado

(3) Total de culturas

As porcentagens de identificação obtidas para cada soro hiperimune (tabelas $10 \mathrm{e}$ 17) sugerem que deve haver uma diferença de padrão antigênico, conforme a origem da estirpe em teste; se na forma de suspensão de células cultivadas em laboratório ou na de suspensão de células provenientes de macerado de nódulos (bacteróides). Por exemplo, os sorogrupos IV e VI que apresentaram ocorrências de $29,6 \%$ e $12,1 \%$ quando em cultura pura (tabela 10), e de $13 \%$ e 3,1\% quando em bacteróide (tabela 18), respectivamente. Diferenças no padrão antigênico entre bactérias oriundas de cultivo "in vitro" e bacteróides, foram verificados por KANNENBERG et al (1994) e LEMOS (1994).

KANNENBERG et al (1994), analisando a expressão de epitopos de LPS em bacteróides oriundos de nódulos de ervilha, utilizando anticorpos monoclonais como sondas imunocitoquímicas, observaram que a região de amostragem, o tamanho e o 
estágio de desenvolvimento do nódulo, influenciam a expressão dos epítopos de LPS. Esses autores sugerem que as modificações das estruturas do LPS podem ter um papel importante na adaptação do endossimbionte às condições das células hospedeiras e que as condições fisiológicas do meio influenciam na estrutura do LPS das bactérias de vida livre.

Van BRUSSEL et al. (1977) observaram que a parede celular de bacteróides de R. leguminosarum continham muito menos LPS, o que poderia ter consequências importantes quando da utilização dos soros anti-LPS na identificação desses endosimbiontes.

A não identificação de uma média de $39,5 \%$ dos nódulos em rotação soja/milho e $67,2 \%$ em soja/cana, pode ser consequência da existência de estirpes, nas duas rotações, com características antigênicas diferentes das 4 utilizadas na produção dos soros hiperimunes, ou devida à instabilidade dos antígenos somáticos na população de rizóbios, fato este também abordado por DUDMAN (1977).

EAGLESHAM (1987), citado por LOMBARDI (1995), considera que o uso de pesticidas, poluição com metais pesados e adubação química, podem agir como mutagênicos. Portanto, diferenças no manejo da cultura da cana pode ter sido um fator a alterar as comunidades de rizóbios do solo, interferindo na ocorrência e caracterização dos mesmos.

HUNGRIA et al. (1994) estudando sobre a adaptação de microrganismos ao cultivo, observaram que a população microbiana é extremamente dinâmica e se adapta às modificações que ocorrem no solo devido às práticas culturais empregadas. Esses mesmos autores observaram também que a comparação de parâmetros morfológicos, fisiológicos, bioquímicos e genéticos entre diversos isolados de $B$. japonicum dos sorogrupos SEMIA 566 e SEMIA 586 após alguns anos de cultivo na região do cerrado e na região sul indicou diferenças substanciais entre a estirpe parental e os novos isolados. LOPES, E.S. \& VOLTAN, R.B.Q. (comunicação pessoal) observaram considerável variação nas características colôniais das estirpes SEMIA 587 e 5019, associadas à variações anatômicas dos nódulos. De seis variantes da SEMIA 587, apenas uma apresentou eficiência semelhante à da parental. 
$O$ alto índice de estirpes não identificadas para as áreas de cultivo soja/cana pode também estar associado a uma maior ocorrência de Bradyrhizobium spp nessa área. Uma maior porcentagem de nódulos formados por rizóbios do antigo grupo "cowpea" certamente interfereria na caracterização de estirpes a partir de soros hiperimunes preparados com células de $B$. japonicum.

O efeito da população nativa de rizóbios, na nodulação pode ser verificado pela porcentagem de nódulos não colonizados pelas estirpes recomendadas. Em cultivo soja/milho 15 e $21,7 \%$ dos nódulos apresentaram-se colonizados pelas estirpes recomendadas SEMIA-587 e 5019, respectivamente. Já para o plantio soja/cana os valores desses mesmos parâmetros foram de 3,2 e 4,2 \% respectivamente.

Em ambos os sistemas de cultivo, dentre os 4 soros hiperimunes testados, a estirpe que apresentou maior predominância foi a SEMIA-5052, que reagiu com 19,5 e 23,7\% dos nódulos, nos plantios soja/milho e soja/cana respectivamente. Alta porcentagem $(38,75 \%$ em tratamento sem inoculação) dessa mesma estirpe foi também verificada por LIMA (1995) trabalhando com nódulos de soja coletados em diferentes épocas de amostragem em experimento de inoculação, conduzido em Latossolo Vermelho Escuro, na região de São Joaquim da Barra, em área de rotação de soja com cana de açúcar. A alta porcentagem de nódulos associados ao sorogrupo I pode ser explicada pela vasta utilização da estirpe SEMIA 5052, a partir de sua introdução em 1952 (VARGAS et al,1994). Os resultados preliminares da eficiência relativa das estirpes deste sorogrupo (tabela 14) sugerem que a eficiência dela é menor que a das estirpes recomendadas, e abaixo do desejado. Já o AS-566 reagiu com poucos nódulos em ambos os cultivos, indicando que estirpes relacionadas ao sorogrupo VI não constituem uma parcela muito significativa na comunidade de rizóbios naturalizados na área de amostragem; a eficiência desse sorogrupo também é baixa.

Os dados obtidos também sugerem que na ausência da planta hospedeira, por um período de até 6 anos (como nas áreas de rotação soja/cana amostradas), a sobrevivência das estirpes recomendadas ainda ocorre, porém pode ser muito menor que na rotação soja/milho, na qual a soja é plantada anualmente (tabela 21).

LEMOS (1994), em teste de aglutinação direta de células de rizóbios que nodulam soja com soros hiperimunes de Bradyrhizobium spp, verificou que as estirpes SEMIA- 
$5000,587,5018,5013$, e 5019 apresentavam reação com os soros das estirpes de Bradyrizobium spp do tipo "cowpea" (Jab 201 e SEMIA 6132, 6146, 6148, 6152 e 6158). Reações cruzadas entre estirpes recomendadas, SEMIA 587 e 5019 e soros hiperimunes de Bradyrhizobium spp sugerem que o uso de soros hiperimunes das estirpes recomendadas pode superestimar a presença destas estirpes nos nódulos coletados em condições de campo, o que erroneamente indicaria uma maior competitividade das mesmas, ou presença e sobrevivência de estirpes em locais onde na realidade elas não ocorrem. Outros pesquisadores como LEONARD (1923) e SEARS (1927), observaram anteriormente que estirpes de Rhizobium japonicum formaram nódulos em Vigna unguiculata (cowpea) e Macroptilium atropurpurem (siratro).

Tabela 21. Distribuição porcentual de 891 culturas, por sorogrupos, nas áreas amostradas em sistema de rotação soja/milho e soja/cana e médias desses dois sistemas de rotação.

\begin{tabular}{lccccccc}
\hline $\begin{array}{l}\text { Sistema de } \\
\text { rotação }\end{array}$ & \multicolumn{7}{c}{ Sorogrupos } \\
& I & III & IV & VI & VIII & IX & NI \\
\hline & & & & & & \\
\hline soja/milho (447) & 19,2 & 15,4 & 23,2 & 5,1 & 0,9 & 1,3 & 34,9 \\
soja/cana (444) & 25,4 & 4,0 & 6,1 & 3,1 & 0,2 & 0,5 & 60,7 \\
\hline \multicolumn{1}{c}{ Médias } & 22,3 & 9,7 & 14,7 & 4,1 & 0,6 & 0,9 & 47,8 \\
\hline
\end{tabular}

KEYSER et al. (1982), em ensaios de aglutinação direta, também observaram reação cruzada entre estirpes de rizóbios que nodulam soja com Bradyrhizobium sp (grupo "cowpea"). Esses mesmos autores apontam que as estirpes USDA 33 e USDA 74 são mais eficientes na FBN quando em associação simbiotica com siratro ou cowpea do que com a soja, embora tais estirpes tenham sido isoladas de soja e por isso classificadas como Bradyrhizobium japonicum. Por isso, acreditam que a designação de bactérias como B. japonicum ou Bradyrhizobium spp ("cowpea") baseada em inoculações cruzadas com plantas, é dúbia, já que ambos os grupos nodulam soja e algumas leguminosas tropicais associadas ao denominado grupo de inoculação cruzada do "cowpea". A classificação de rizóbios dessa forma não é válida, visto que há possibilidade de ocorrência de $B$. elkanii autoctone em nossos solos que apresentam reação sorológica cruzada com as 
espécies de Bradyrhizobium spp e B. japonicum. A ocorrência de $B$. elkanii em nossas condições, esclarece a afirmativa de LOPES (1976 a) quanto a ausência de bactérias autoctones que nodulam soja, questionada por outros autores.

A verificação de tais fatos torna insegura a caracterização por meio de técnicas de aglutinação, visto que não há reações específicas que permitam reconhecer a homologia de reações dos isolados com somente um soro hiperimune. Portanto, em estudos de ecologia de rizóbios, a técnica de aglutinação direta deve se restringir a casos muito específicos, devendo, na maioria dos casos estar associada a outras técnicas. 


\section{5- CONCLUSÕES}

Com base nos resultados obtidos e para as condições do experimento, pode-se concluir que:

1- As comunidades de rizóbios estudadas nas diferentes propriedades e nos diferentes isstemas de cultivo mostraram-se composta por estirpes de seis sorogrupos identificadas e relacionadas às estirpes 5052 (sorogrupo I); 587 (sorogrupo III); 5019 (sorogrupo IV); 566 (sorogrupo VI); 5061 (sorogrupo VIII) e 518 (sorogrupo IX).

2- As estirpes de rizóbios isoladas mostraram na sua maioria, baixa eficiência de fixação de $\mathrm{N}_{2}$. Dezesseis estirpes isoladas em área de cultivo soja/milho (SMS$790,799,800,802,805,814,816,818,819,823,830,833,834,836,839$ e 843$)$, e oito da área soja / cana (SMS-863,864,865,872,882,884,885 e 919), mostraram eficiência comparável à SEMIA 587, recomendada para a produção de inoculantes.

3- A média de eficiência relativa para os isolados de área em cultivo soja/milho (80\%) foi superior e significativamente diferente da dos isolados em área de cultivo soja/cana (71\%).

4- As estirpes do sorogrupo III (SEMIA 587), sobressairam-se quanto a eficiência de fixação de $\mathrm{N}_{2}$ em ambos os sistemas de cultivo.

5- As estirpes dos sorogrupos I (SEMIA 5052) e IV (5019), isoladas das áreas de cultivo soja/cana, apresentaram menor eficiência de fixação de $\mathrm{N}_{2}$ do que as do mesmo sorogrupo isoladas das áreas de cultivo soja/milho.

6- As estirpes do sorogrupo I (SEMIA 5052), mostraram-se mais competitivas do que as recomendadas (SEMIA 587 e SEMIA 5019) e do que as dos demais sorogrupos. 


\section{6 - REFERÊNCIAS BIBLIOGRÁFICAS}

AMARGER, N. \& LOBREAU, J.P. Quantitative study of nodulation competitiveaness in Rhizobium strains. Applied Environmental Microbiology, v. 44, n.3,p.583-6, 1982.

ARAÚJO, R.S.; ROBLETO, E.A. \& HANDELSMAN, I. A hydrophobic mutant of Rhizobium eflii altered in nodulation competitiveness and growth in the rhizosphere. Applied Environmental Microbioly, v. 60, p.1430-6, 1994.

BIER, O. Reaçốes Sorológicas. In: Methoramentos Ed., Microbiologia e Imunologia, 23a ed.1984. p. 315-365.

BOHLOOL, B.B.; LADHA, J.K.; GARRITY, D.P. \& GEORGE, T. Biological nitrogen fixation for sustainable agriculture: $A$ perspective. Plant and Soil, v.141, p.1-11, 1992.

BOONKERD, N.; WEBER, D.F.; BEZDICEK, D.F. Influence on Rhizobium japonicum strains and inoculation methods on soybean growth in Rhizobiapopulated soil. Agronomy Journal, v. 70, p. $547-9,1978$.

BORDELEAU, L. M. \& PROVOST, D. Nodulation and nitrogen fixation in extreme environments.Plant and Soil, v.161, p.115-25,1994.

CALDWELL, B.E. Initial competition of root-nodule bacteria on soybeans in a field environment. Agronomy Journal, v.61, p.813-5, 1969.

CARARETO ALVES, L.M. \& LEMOS, E.G.M. Use of lipopolysaccharide for immunological characterization of Bradyrhizobium sp. Soil Biochemistry, 1993. 
CARROF, M.; CHABY, R.; KARIBIAN, D; PERRY, J.; DEPRUN, C; SZABP, L. Variations in the carbohydrate regions of Bordetella pertussis lipopolysaccharides: Electrophoretic, serological and structural features. Joumal Bacteriology, v.172, p.1121-8, 1990.

DATE, R.A. \& DECKER A.M. Minimal antigenic constitution of 28 strains of Rhizobium japonicum. Canadian Journal of Microbiology, v.11, p.1-8, 1965.

DOBEREINER, J.; ARRUDA, N.B. \& PENTEADO, A. F. Avaliação da fixação do nitrogênio em leguminosas pela regressão do nitrogênio total das plantas sobre o peso dos nódulos. Pesquisa Agropecuária Brasileira, v.1, p. 233-8, 1966.

DOBERENER, J.; FRANCO, A.A. \& GUZMAN, I. Estirpes de Rhizobium japonicum de excepcional eficiência. Pesquisa Agropecuária Brasileira, v.5, p.155-2, 1970.

DUDMAN, W.F. Immune diffusion analysis of the estracelular Aduble antigens of two strains of Rhizobium meliloti .Journal Bacteriology, v.88, p.782-94, 1964.

DUDMAN, W.F. Serological methods and their application to dinitrogen-fixing organisms. In: HARDY, R.W.F; GIBSON, A.H. eds. A treatise on dinitrogenfixation. New York: John Wiley \& Sons, 1977. cap. 4, p. 487-508 (Agronomy and Ecology).

EAGLESHAM, A.R.J. \& SINCLAIR, M.J. Identification and characterization or Rhizobia using the Elisa Techinique. Nitrogen Fixation by Legumes in Mediterranean Agriculture. Netherlands, 1988.

FONSECA, S.M.; SAITO, S.M.T. \& VIDOR, C. A vantagem dos mutantes resistentes à streptomicina. Pesquisa Agropecuária Brasileira, v.20, p. 609-14, 1985.

FREIRE, J.R.; KOLLING, J.; VIDOR, C.; PEREIRA, J.S.; KOLLING, I.G.; MENDES, N.G. Sobrevivência e competição por sítios de nodulação de estirpes de Rhizobium japonicum na cultura da soja. Revista Brasileira de Ciência do Solo, v.7, p.4753,1983 . 
FREIRE, J.R. Fixação do Nitrogênio Pela Simbiose Rizóbio/Leguminosa. In: CARDOSO, E.J.B.N.; TSAI, S.M.; NEVES, M.C.P. Microbiologia do solo. Campinas: Sociedade Brasileira de Ciência do Solo, 1992. cap.9. p.121-40.

FREIRE, J.R. \& VIDOR, C. Rhizobiologia. In: MIYASAKA, S. \& MEDINA, J.C. $\underline{\text { A }}$ soja no Brasil. Campinas: ITAL,1981. cap. 9, p.417-425.

FUQUAY, J.I.; BOTTOMLEY, P.J. \& JENKINS, M.B. Complementar methods for differentiation of Rhizobium meliloti isolates. Applied Environmental Microbiology, v.47, p. 663-9, 1984.

HADRY, H.; BALICK, M. \& SCHERWATER, B. Application of random amplified polymorphic DNA (RAPD) in molecular ecology. Molecular Ecology v.1, p. 55-63, 1992.

HARDY, R.W.F.;FLNER, P.; HAGEMAN. Nitrogen input. In: BROWN, A. W. A. ed. Crop productivity; research imperative. Michigan: Agricultural Experiment Station. 1975.p.133-76.

HAM, G.E.; CARDWELL, V.B. \& JOHNSON, H.W. Evaluation of Rhizobium japonicum inoculants in soils containing naturalized populations of Rhizobia. Agronomy Journal, v. 63, p.301:3, 1971.

HUNGRIA, M.; ANDRADE, D.S.; COLOZZI Fo, A.; BALOTA, E.L. \& CATTELAN, A.J. Ecologia microbiana em solos sob cultivo na região sul do Brasil. In: SIMPÓSIO BRASILEIRO SOBRE MICROBIOLOGIA DO SOLO, 3., Londrina, 1994. Resumos. Londrina: IAPAR, 1994.

IPAGRO - MIRCEN. Rhizobium and Bradyrhizobium culture collection catalogue, 6th. ed., Porto Alegre, 1991, 41p.

JOHNSON, H.W.; MEANS, V.M. \& WEBER, C.R. Competition for nodule sites between strains of Rhizobium japonicum applied as inoculum and strains in the soil. Agronomy Journal, v. 57 , p. 179-85, 1965 . 
JONES, M.B.; BURTON, J.C.; VAUGHN, C.E. Role of inoculation in establishing subclover on California annual grasslands. Agronomy Journal, v. 70, p.1081-5, 1978.

KAMICHER, B.I. \& BRILL, W.I. Identification of Bradyrhizobium japonicum nodule isolates from Wisconsin Soybean Farms, Applied Environmental Microbiology, v.51, n.3, p.487-92, 1986.

KAMICKER, B.J. \& BRILL, W.J. Methods to alter the recovery and nodule location of Bradyrhizobium japonicum inoculant strains on field-grown soybeans. Applied Environmental Microbiology, v.53, p.1737-42, 1987.

KANNENBERG, E.L.; PEROTTO, S.; BIANCIOTTO, V.; RATHBUN, E.A.;BREWIN, N.J. Lipopolysaccharide epitope expression of Rhizabium bacteroids as revealed by in situ immunolabelling of pea root nodule sections. Journal Bacteriology, v. 176, n.7, p.2021-32, 1994.

KAPUSTA, G. \& ROUWENHORST, D.L. Influence of inoculum size on Rhizobium japonicum serogroup frequency in soybean nodules. Agronomy Journal, v. 65, p. 916-9, 1973.

KEYSER, H.H., van BERKUM, P., WEBER, D.F. A comparative study of the physiology of simbioses formed by Rhizobium japonicum with Glycine max, Vigna unguiculata, and Macroptilium atropurpurem. Plant Physiology, v. 70, p.1626-30, 1982.

KEYSER, H.H. \& WEBER, D.F. USDA-Betsville Rhizobium culture collection catalogue. 1979. (PPHI REPORT,16).

KOOLING, J; GODINHO, I \& PEREIRA, J. Competição, sobreviência e especialização simbiótica de estirpes de soja. In: Reunião Conjunta de Pesquisa de soja, RS/SC, 4., Santa Maria, 1976. Ata. Santa Maria, 1976.

KUCEY, R.M.N. \& HYNES, H.F. Populations of Rhizobium leguminosarum biovar phaseoli and viceae in fields after bean or pea in rotation with nonlegumes. Canadian Journal of Microbiology, v. 35, p.661-7, 1989. 
LAEMMLI, U.K. Cleavage of structural proteine during the assembly of the head of bacteriophage. T4. Nature, v. 227, p. 680-5, 1970.

LEMOS, E.G.M. Classificação e identificação de bradirrizóbios que nodulam soja por análise dos padrões isoenzimáticos, sorologia, morfologia de colônias e atividade de hidrogenase. Jaboticabal.1994.108p. Tese (Livre Docência), Universidade Paulista "Júlio de Mesquita Filho".

LEMOS, E.G.M.; CAMPANARO, J.C.; ALVES, L. M.C. Identificação de Bradyrhizobium através de lipopolissacarídeos em SDS-PAGE. In: REUNION LATINOAMERICANA DE RHIZOBIOLOGIA, 15. Guatemala, 1990.

LEONARD, L.T. Nodule production kinship between the soybean and the cowpea. Soil Science, v. 15, 277-83, 1923.

LIMA, S. C. Dinâmica da nodulação, caracterização de Bradyrhizobium japonicum e produção de soja a campo. Piracicaba.1995. 75p. Dissertação (Mestrado)- Escola Superior de Agricultura "Luiz de Queiroz", Universidade de São Paulo.

LOMBARDI, M.L.C.O. Diversidade de rizóbios nativos de solos do estado de São Paulo. Piracicaba,1995.164p.Tese (Doutorado)- Escola Superior de Agricultura "Luiz de Queiroz", Universidade de São Paulo.

LOPES, E.S. Inoculantes para leguminosas- importância, produção e controle de qualidade. $\mathrm{O}$ agronômico. v.27/28, p. 73-83, 1975/1976.

LOPES, E.S.; GIARDINI, R.A. RIZOBIOLOGIA. Estudos no Estado de São Paulo, In: MTYSAKA, S. \& MEDINA, J.C.A soja no Brasil. Campinas: ITAL, 1981. p.42536.

LOPES, E.S.; GIARDINI, R.A.; KIIHL, R.A.S. Presença e eficiência de Rhizobium japonicum em solos cultivados ou não com soja, no Estado de São Paulo. BRAGANTIA, v.35, p. 389-96, 1976 a. 
LOPES, E.S. ; GIARDINI, R.A.; KIHL, R.A.S.; IGUE,T. Especificidade hospedeira e pré-seleção de estirpes de Rhizobium japonicum para as variedades Santa Rosa, Viçosa e IAC-2 de soja. BRAGANTIA, v. 35, p.1-11, 1976 b.

LOPES, E.S.; GIARDINI, A.R; SANCHES, L. Sobrevivência de Rhizobium japonicum em turfa esterilizada com radiação gama. BRAGANTIA, v.39, p.205-9, 1980.

LOPES, E.S; KOLLING, J.K. Problemas de produção, fiscalização e eficiência de inoculantes no Brasil. In: I SIMPÓSIO SOBRE A CULTURA E PRODUTIVIDADE DA SOJA, Piracicaba,1991. Anais. Piracicaba: 1992. p.143-51.

MALAVOLTA, E. Nutrição Mineral. In: FERRI, M.G. Fisiologia Vegetal. 2. ed. São Paulo: EPV, 1979. cap. 2. p.77-97.

MASCARENHAS, H. A. A.; HIROCE, R.; BRAGA, N. R.; MIRANDA, M. A. C.;BULISANI, E. A.; POMMER, C. V.; SAWAZAKI, E.; GALLO, P. B.; PEREIRA, J. C. V. N. A. Efeito do nitrogênio residual de soja na produção do milho. Campinas. Instituto Agronômico. Campinas: Instituto Agronômico,1983. 24p.(Boletim técnico, 58).

MTYASAKA, S. Contribuição para o melhoramento da Soja no Estado de São Paulo. Piracicaba, 1958. 47p. Tese (Doutorado)- Escola Superior de Agricultura "Luiz de Queiroz", Universidade de São Paulo.

MUNNS, D. N. \& KEYSER, H. H. Tolerance of rhizobia to acidity, aluminium and phosphate. Soil Science Society American Journal, v. 34, p.519-23,1981.

MURRAY, J.; FIXTER, L.M.; HAMILTON, I.D.; PEROMBELON, M.C.M.; QUINN, C.E.; GRAHAM, D.C. Serogroups of potato pathogenic Eminia carotovora strains: identification by lipopolysaccharide eletrophoretic patterns. Journal Applied Bacteriology, v. 66, p. 231-40, 1990.

NOEL, K.D. \& BRLL, J. Diversity and dinamics of indigenous Rhizobium japonicum populations. Applied Environmental Microbiology, v.40, p. 931-8, 1980. 
NORRIS, D.O. Legumes and the Rhizobium symbiosis. Empire Journal of Experimental Agriculture, v.24 (96). 1956.

OLSEN, P.E. \& RICE, W.A. Bradyrhizobium strain identification and quantification in commercial inoculants by immunoblot anaysis. Applied Environmental Microbiology, v.55, p. 520-2, 1989.

OLSEN, P.E.; RICE, W.A.; STEMKE, C.W.; PAGE, W.J. Strain-specific serological techniques for the identification of Rhizobium melilot in in commercial alfafa inoculants. Canadian Joumal Microbiology, v.28, p.225-30, 1983.

PRADO, H. Levantamento pedológico semidetalhado de uma área da região nordeste do Estado de São Paulo. Piracicaba.1993. 159p. Tese (Doutorado)- Escola Superior de Agricultura "Luiz de Queiroz", Universidade de São Paulo.

RAIJ, B. van; SILVA, N.M. da; BATAGLIA, O.C.; QUAGGIO, J.A.; HIROCE,R; CANTARELlA, H.; LELINAZZI J., D.; DECHEN, A.R.; TRANI, P.E. Recomendações da adubação e calagem para o Estado de São Paulo. Campinas: Instituto Agronômico, 1985.107p. (Boletim Técnico, 100).

RUMJANEK, N.G.; DOBERT. R. C.; BERKUM, P.van \& TRIPLETT, E.W. Common Soybean Inoculant Stains in Brazil are Members of Bradyrhizabium elkanii. Applied Environmental Microbiology, v.59, p. 4371-3, 1993.

RUSCHEL, A.P. Metabolismo do Nitrogênio. In: FERRI, M.G. Fisiologia Vegetal. 2.ed. São Paulo: EPV, 1979. cap.4, p.169-212.

SEARS, O.H. \& CARROLL, W.R. Cross inoculation with cowpea and soybean nodule bacteria. Soil Science, v.27, p. 413-9.1927.

SINGLETON, P.W. \& TAVARES, J.M. Inoculation response of legumes in relation to the number and effectiveness of indiginous - thizobium populations. Applied Environmental Microbiology, v.51, p. 1013-8, 1986.

SOMASEGARAM, P. \& HOBEN, H.J. Methos in legume - Rhizobium tecnology. NIFTALMIRCEN, $1985.367 \mathrm{p}$. 
STREETER, J.G. A persistent paradox: Nitrogen nutrition of soybeans. Ohio Report on Research an Development in Agriculture, Wooster, v.58, p.37-9, 1973.

SUTHERLAND, W. N. SHRADER, W. J.; PESEK, J.T. Efficiency of legume residue nitrogen and inorganic nitrogen in corn production. Agronomy Journal, v.53, p.33942,1961 .

TANAKA, T.T. \& MASCARENHAS, H.A.A.. Soja. Nutrição, correção do solo e adubação. Campinas: Fundação Cargill, 1992. 60p. (Série Técnica, 7).

THOMPSON, J.A.; ROUGHLEY, R.J. \& HERRIDGE, D.F. Criteria and methods for comparing the effectiveness of Rhizobium strains for pasture legumes under field conditions. Plant and Soil, v.40, p. 511-24, 1974.

TSAI, C. M., FRASCH, C.E. A sensitive silver stain for detecting lipopolysaccharides in polyacrilamide gels. Analytical Biochemistry, v. 119, p.115-9, 1982.

TRIPLETT, E.W.; ALBRECHT, K.A. \& OPLINGER, E. Crop rotation effects on populations of Bradyrhizobium japonicum and Rhizobium meliloti. Soil Biology Biochemistry, v.25, n.6, p.781-4, 1993.

van BRUSSEL, A.A.N.; PLANQUO, K. \& QUISPEL, A. The wall of Rhizobium leguminosarum in bacteroid and free-living forms. Journal of General Microbiology, $\underline{101}$ p.51-6, 1977.

VARGAS, M.A.T. \& SHUET, A.R. Adubação nitrogenada, inoculação e épocas de calagem para a soja em um solo sob Cerrado. Pesquisa Agropecuária Brasileira v.17, n.8,.p.1127-32, 1982.

VARGAS, M.A.T.; PERES, J.R.R. \& SHUET, A.R. Adubação nitrogenada e inoculação soja em solos de Cerrado. Planaltina: EMBRAPA-CPAC, 1982.11p. (Comunicado Técnico, 13).

VARGAS, M.A.T.; MENDES, I.C.; SHUET, A.R. \& PERES, I.R.R. Fixação biológica do nitrogênio. In: ARANTES, N.E. \& SOUZA, P.I.M. Cultura da Soja nos cerrados. São Paulo: POTAFOS, 1993, p.159-82. 
VARGAS, M.A.T.; MENDES, I.C; SUHET, A.R.; PERES, J.R.R. Inoculation of soybean in cerrado soils with established populations of Bradyrhizobium japonicum. Revista de Microbiologia, v.25, n.4, p. 245-50, 1994.

VEST, G. D. Nitrogen increases in a non-nodulating soybean genotype grown with nodulating genotype. Agronomy Journal. v.63, p.356-9, 1971.

VIDOR, C.; BROSE, E. \& PEREIRA, J.S. Competição por sítio de infecção nodular entre estirpes de Rhizobium japonicum em cultivares de soja (Glycine max (L) Merr.). Agron. Sulriograndense, v.15, n.2, p.227-38, 1979.

VIDOR, C.; KOLLING, J.; FREIRE, J.I.; SCHOLLES, D.; BROSE, E.; PEDROSO, T.M.H. Fixação Simbiótica do Nitrogênio pela simbiose entre Rhizobium e Leguminosas. Porto Alegre: IPAGRO, 1983. 51p. (Boletim Técnico 11)

VINCENT, J.M. Serological studies of the root - nodule bacteria. I. Strains of Rhizobium meliloti. Proceedings of the Linnean Society of New South Wales, v.66, p.145-54, 1941.

VINCENT, J.M. The root nodule bacteria of pasture legumes. Proceedings of the Linnean Society of New South Wales, v. 79, p.1-32, 1954.

VINCENT, J.M. A manual for the practical study of root-nodule bacteria. Oxford: Blackell, 1970. ( IBP Handbook n.15)

WEAVER, R.W. \& FREDERICK, L.R. Effect of inoculum rate on competitive nodulation o Glycine max (L.) Merrill, Field Studies. Agronomy Journal, v, 66, p.233-6, 1974.

WEBER, C.R. Nodulating and non-nodulating soybean isolines: II. Response to applied nitrogen and modified soil conditions. Agronomy Journal, v. 58, p. 46-9, 1966. 


\section{APÊNDICE 1- QUESTIONÁRIO PARA LEVANT AMENTO DE DADOS SOBRE NODULAÇÃO DE SOJA}

I- Propriedade:

.Nome do proprietário:

.Endereço:

.Cidade:

.Localização:

.Nome da propriedade:

Gleba:

II- Histórico da Gleba:

.Tipo de solo:

.Cultivos anteriores:

Cultura Produção Ano

1.

2.

3.

.Adubação e calagem efetuados indicar a fórmula ou adubo e calcário utilizados:

Ano
ou fórmula $\quad \begin{gathered}\text { Calcário } \\ \text { ton/ha }\end{gathered}$

1.

2.

3.

.Produtividade média da soja na última colheita: 
III-Informações sobre a lavoura da soja amostrada:

.Cultivar:

.Data de plantio:

.Usa inoculante? sim não

.Qual o inoculante usado?

.Fez calagem antes do plantio da soja? sim กล̃o

.Em que dose?

.Fez adubação? sim não

Fórmula:

.Dose:

IV-Inoculantes e Inoculação:

.Conhece o inoculante? sim_ não

.Já utilizou o inoculante em soja? sim กão

.Já utilizou em outras leguminosas? sim não

.Verificou a nodulação: sim กão

.Como conserva o inoculante?

( ) geladeira

( ) fora da geladeira

( ) outra forma . Explique:

.Em que dose usa o inoculante?

Como inocula?

( ) mistura o inoculante com gua e trata a semente

( ) a seco na sementeira

( ) outra maneira. Explique:

Usa adubo nitrogenado quando inocula?

.Que dose aplica de nitrogênio?

.É fácil encontrar inoculante para a soja?

.Verifica a nodulação na lavoura de soja?

.Considera que a inodulação dá um resultado positivo? 


\section{APÊNDICE 2- MEIO DE CULTURA MANITOL EXTRATO DE LEVEDURA}

(YMB):

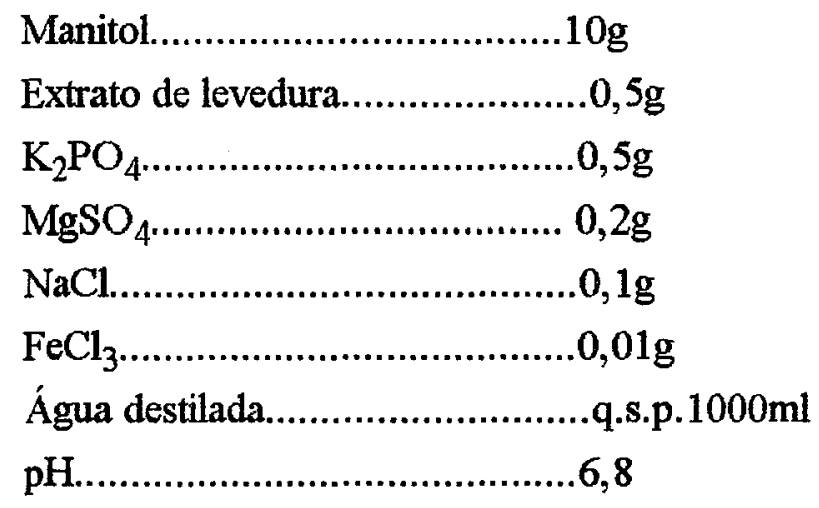

-Meio sólodo para placas (YMA):

YMB...............................1000ml

Ágar.......................................18g

Solução Estoque A.....................10ml

-Meio para tubos:

* Sólido:

YMB..........................1000ml

Ágar..............................18g

Solução estoque B...................5ml

* Líquido:

YMB.......................1000ml

Solução estoque B..................5ml

-Soluções Estoques:

Solução estoque $A$ : vermelho congo...................1g água destilada.......................s.p.400ml 
Solução estoque B: azul de bromotimol. . .19 q.s.p. $200 \mathrm{ml}$

APÊNDICE 3- SOLUÇÃO NUTRITIVA PARA VASOS DE LEONARD:

$\mathrm{KCl}$. $0,149 \mathrm{~g}$

$\mathrm{K}_{2} \mathrm{PO}_{4}$ $.0,348 \mathrm{~g}$

$\mathrm{MgSO}_{4} \cdot 7 \mathrm{H}_{2} \mathrm{O}$ $.0,493 \mathrm{~g}$

$\mathrm{CaSO}_{4} \cdot 2 \mathrm{H}_{2} \mathrm{O}$. $.0,688 \mathrm{~g}$

Solução Estoque 1 $0,500 \mathrm{ml}$

Solução Estoque 2 $0,500 \mathrm{ml}$ Água destilada. ..q.s.p. $1000 \mathrm{ml}$

Solução Estoque 1:

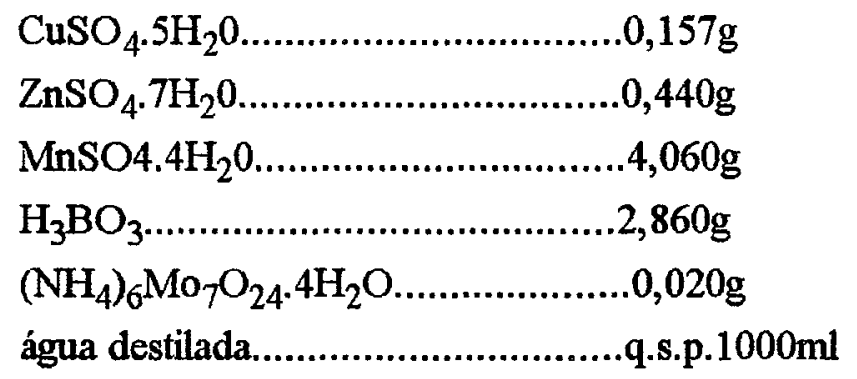

Solução Estoque 2:

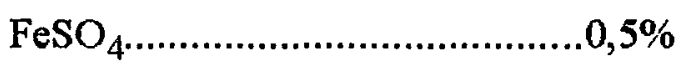

ácido cítrico................................. $0,5 \%$ 
APÊNDICE 4- TAMPÕES, SOLUÇÕES E GÉIS:

TAMPÃO DA AMOSTRA DE LIPOPOLISSACARÍDEO:

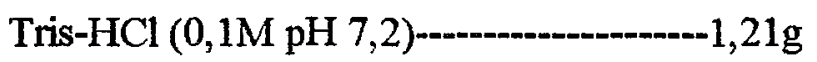

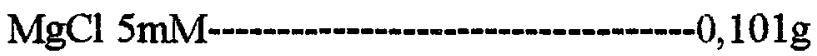

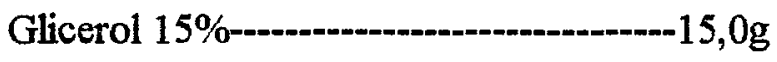

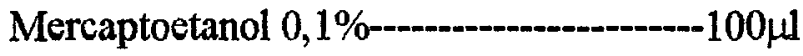

$\mathrm{H}_{2} \mathrm{O}$ destilada---o-n.

SOLUÇÃO DE CLORONAFTOL:

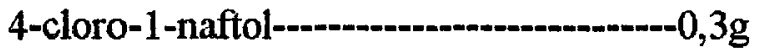

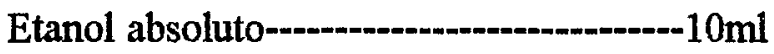

Esta solução deve ser mantida a -200C

TAMPÃO FOSFATO (PBS):

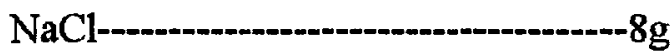

$\mathrm{KCl}-\mathrm{N}_{-}$

$\mathrm{NaH}_{2} \mathrm{PO}_{4}$

$\mathrm{KH}_{2} \mathrm{PO}_{4}$

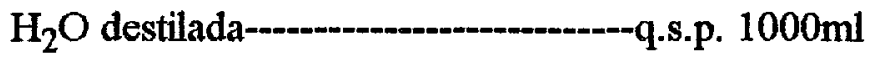

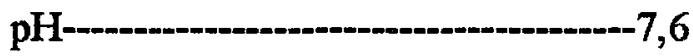

GEL DE SEPARAÇÃO (13\% SDS PAGE)

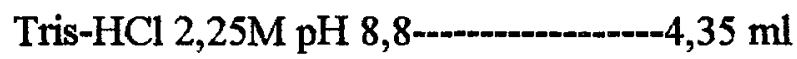

Acrilamida-Bis (30\%; 0,8\%)---.-------11,31ml

$\mathrm{H}_{2} \mathrm{O}$ deionizada--_-_-_-_-_,

SDS 4\%-1- $0,65 \mathrm{ml}$

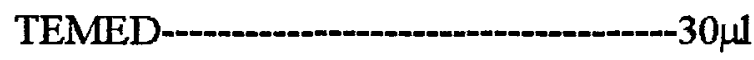

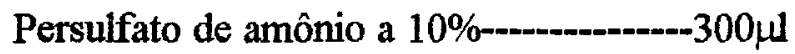


GEL DE EMPILHAMENTO (5\%)

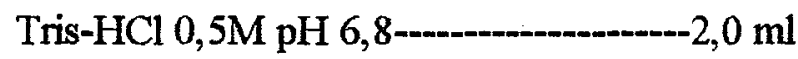

Acrilamida-Bis-a--a-1,33m

$\mathrm{H}_{2} \mathrm{O}$ deionizada---:-

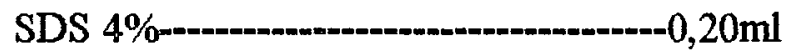

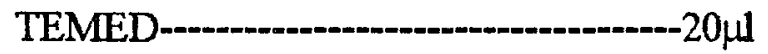

Persulfato de amônio a 10\%-------------80

REAGENTE DE COR

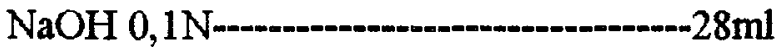

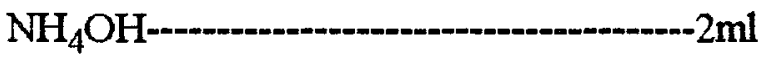

Nitrato de Prata 20\%--

$\mathrm{H}_{2} \mathrm{O}$ deionizada--

(Obs.: O reagente de cor deve ser preparado e usado imediatamente)

SOLUÇÃO DE FORMALDEÍDO (REVELAÇÃO)

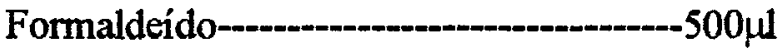

Ácido cítrico-_.-5

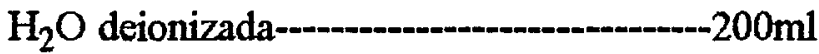




\section{APÊNDICE 5- TABELAS}

5.1. Identificação de 91 estirpes isoladas de soja, por sorogrupo, número da Seção de Microbiologia- IAC (SMS), número do teste de nodulação preliminar de eficiência (TNPE), e dados obtidos em vasos de Leonard, em casa de vegetação, para matéria seca da parte aérea (MSPA), número e peso de nódulos secos e eficiência relativa (ER) de plantas agrupadas por propriedade.IAC-8, 50-54 dias após o plantio.

\begin{tabular}{|c|c|c|c|c|c|c|c|}
\hline \multirow{2}{*}{$\begin{array}{c}\quad \mathrm{N}^{\circ} \mathrm{da} \\
\text { propriedade }\end{array}$} & \multirow[t]{2}{*}{ Sorogrupo } & \multirow{2}{*}{$\begin{array}{r}\mathrm{N}^{\circ} \\
\mathrm{SMS}\end{array}$} & \multirow{2}{*}{$\begin{array}{c}\text { No } \\
\text { TNPE }\end{array}$} & \multirow[t]{2}{*}{ MSPA } & \multicolumn{2}{|c|}{ Nódulo } & \multirow[t]{2}{*}{ ER } \\
\hline & & & & & Peso seco & Número & \\
\hline & & & & $\mathrm{g}$ & $\mathrm{mg}$ & & $\%$ \\
\hline & VII & 789 & 1 & 3,88 & 444 & 38 & 60 \\
\hline & III & 790 & 1 & 7,53 & 624 & 44 & $118^{*}$ \\
\hline & IV & 791 & 1 & 4,31 & 380 & 183 & 67 \\
\hline 1 & IV & 792 & 1 & 5,09 & 766 & 112 & 80 \\
\hline & IV & $793 a$ & 1 & 4,55 & 591 & 85 & 71 \\
\hline & IV & 794 & 1 & 4,80 & 854 & 52 & 75 \\
\hline & IV & 795 & 1 & 5,12 & 592 & 53 & 80 \\
\hline & IV & 799 & 1 & 6,50 & 827 & 90 & $102^{*}$ \\
\hline 2 & I & 800 & 1 & 5,84 & 954 & 121 & $91^{*}$ \\
\hline & IX & 801 & 1 & 4,08 & 431 & 108 & 64 \\
\hline & I & 802 & 1 & 7,35 & 1302 & 104 & $115^{*}$ \\
\hline & IV & 805 & 1 & 5,89 & 766 & 81 & $92^{*}$ \\
\hline & IX & 809 & 1 & 2,86 & 706 & 87 & 45 \\
\hline 3 & IX & 810 & 1 & 4,76 & 800 & 77 & 74 \\
\hline & III & 811 & 1 & 4,84 & 566 & 69 & 76 \\
\hline & IV & 813 & 1 & 5,66 & 675 & 72 & 88 \\
\hline
\end{tabular}


5.1. Identificação de 91 estirpes isoladas de soja, por sorogrupo, número da Seção de Microbiologia- IAC (SMS), número do teste de nodulação preliminar de eficiência (TNPE), e dados obtidos em vasos de Leonard, em casa de vegetação, para matéria seca da parte aérea (MSPA), número e peso de nódulos secos e eficiência relativa (ER) de plantas agrupadas por propriedade.IAC-8, 50-54 dias após o plantio (continuação).

\begin{tabular}{|c|c|c|c|c|c|c|c|}
\hline \multirow{2}{*}{$\begin{array}{c}\quad \mathrm{N}^{\mathrm{O}} \mathrm{da} \\
\text { propriedade }\end{array}$} & \multirow[t]{2}{*}{ Sorogrupo } & \multirow{2}{*}{$\begin{array}{c}\mathrm{N}^{\mathrm{O}} \\
\mathrm{SMS}\end{array}$} & \multirow{2}{*}{$\begin{array}{c}\mathrm{N}^{\mathrm{O}} \\
\text { TNPE }\end{array}$} & \multirow[t]{2}{*}{ MSPA } & \multicolumn{2}{|c|}{ Nódulo } & \multirow[t]{2}{*}{ ER } \\
\hline & & & & & Peso seco & Número & \\
\hline & & & & g & $\mathrm{mg}$ & & $\%$ \\
\hline \multirow{6}{*}{4} & IV & 814 & 1 & 5,97 & 688 & 91 & $93^{*}$ \\
\hline & IV & 815 & 1 & 4,97 & 586 & 80 & 78 \\
\hline & VII & 816 & 1 & 6,41 & 811 & 66 & $100^{*}$ \\
\hline & I & 817 & 1 & 5,00 & 720 & 82 & 78 \\
\hline & III & 818 & 1 & 5,98 & 773 & 94 & $93^{*}$ \\
\hline & III & 819 & 1 & 7,20 & 1105 & 13 & $113^{*}$ \\
\hline \multirow{3}{*}{5} & III & 822 & 1 & 5,15 & 668 & 82 & 80 \\
\hline & III & 823 & 2 & 5,40 & 775 & 207 & $102^{*}$ \\
\hline & III & 824 & 1 & 3,12 & 322 & 22 & 49 \\
\hline \multirow{5}{*}{6} & IX & 825 & 2 & 2,94 & 330 & 157 & 55 \\
\hline & I & 826 & 2 & 3,11 & 385 & 168 & 59 \\
\hline & I & 827 & 2 & 4,65 & 647 & 157 & 88 \\
\hline & IX & 828 & 2 & 3,02 & 448 & 131 & 57 \\
\hline & I & 829 & 2 & 3,05 & 380 & 97 & 58 \\
\hline \multirow{8}{*}{7} & IV & 830 & 1 & 6,45 & 968 & 56 & $101^{*}$ \\
\hline & III & 831 & 1 & 4,59 & 800 & 178 & 72 \\
\hline & IV & 832 & 1 & 4,20 & 551 & 43 & 66 \\
\hline & IV & 833 & 4 & 2,20 & 333 & 61 & $100^{*}$ \\
\hline & III & 834 & 1 & 6,34 & 1081 & 85 & $99^{*}$ \\
\hline & VII & 835 & 1 & 5,34 & 704 & 68 & 83 \\
\hline & $I$ & 836 & 1 & 6,03 & 854 & 120 & $94^{*}$ \\
\hline & I & 837 & 2 & 4,31 & 604 & 127 & 81 \\
\hline
\end{tabular}


5.1. Identificação de 91 estirpes isoladas de soja, por sorogrupo, número da Seção de Microbiologia- IAC (SMS), número do teste de nodulação preliminar de eficiência (TNPE), e dados obtidos em vasos de Leonard, em casa de vegetação, para matéria seca da parte aérea (MSPA), número e peso de nódulos secos e eficiência relativa (ER) de plantas agrupadas por propriedade.IAC-8, 50-54 dias após o plantio (continuação).

\begin{tabular}{|c|c|c|c|c|c|c|c|}
\hline \multirow{2}{*}{$\begin{array}{c}\mathrm{N}^{\mathrm{O}} \mathrm{da} \\
\text { propriedade }\end{array}$} & \multirow[t]{2}{*}{ Sorogrupo } & \multirow{2}{*}{$\begin{array}{r}\mathrm{N}^{\mathrm{o}} \\
\mathrm{SMS}\end{array}$} & \multirow{2}{*}{$\begin{array}{c}\mathrm{N}^{\circ} \\
\text { TNPE }\end{array}$} & \multirow[t]{2}{*}{ MSPA } & \multicolumn{2}{|c|}{ Nódulo } & \multirow{3}{*}{$\begin{array}{l}\text { ER } \\
\% \\
\%\end{array}$} \\
\hline & & & & & Peso seco & Número & \\
\hline & & & & g & $\mathrm{mg}$ & & \\
\hline & VII & 839 & 2 & 5,23 & 774 & 98 & $99 *$ \\
\hline \multirow[t]{4}{*}{8} & IV & 842 & 2 & 3,10 & 480 & 192 & 58 \\
\hline & IV & 843 & 2 & 5,01 & 693 & 140 & $95^{*}$ \\
\hline & IX & 844 & 3 & 4,03 & 586 & 76 & 66 \\
\hline & $\mathrm{VI}$ & 848 & 2 & 4,15 & 497 & 115 & 78 \\
\hline \multirow[t]{2}{*}{9} & VI & 849 & 3 & 5,08 & 645 & 106 & 83 \\
\hline & VI & 850 & 3 & 2,99 & 369 & 76 & 49 \\
\hline \multirow[t]{4}{*}{10} & IV & 852 & 2 & 4,04 & 681 & 117 & 76 \\
\hline & IV & 855 & 3 & 4,67 & 600 & 125 & 77 \\
\hline & I & 856 & 2 & 2,87 & 386 & 94 & 54 \\
\hline & I & 858 & 2 & 2,93 & 412 & 135 & 55 \\
\hline \multirow[t]{5}{*}{11} & I & 859 & 2 & 2,42 & 235 & 71 & 46 \\
\hline & I & 860 & 2 & 3,01 & 403 & 127 & 57 \\
\hline & VI & 861 & 2 & 3,70 & 475 & 130 & 70 \\
\hline & IV & 862 & 2 & 2,14 & 298 & 145 & 40 \\
\hline & IV & 863 & 2 & 5,38 & 820 & 146 & $102^{*}$ \\
\hline \multirow[t]{3}{*}{12} & III & 864 & 2 & 5,42 & 717 & 104 & $102^{*}$ \\
\hline & III & 865 & 2 & 5,17 & 684 & 111 & $98^{*}$ \\
\hline & $\mathrm{VI}$ & 866 & 2 & 4,66 & 570 & 159 & 88 \\
\hline
\end{tabular}


5.1. Identificação de 91 estirpes isoladas de soja, por sorogrupo, número da Seção de Microbiologia- IAC (SMS), número do teste de nodulação preliminar de eficiência (TNPE), e dados obtidos em vasos de Leonard, em casa de vegetação, para matéria seca da parte aérea (MSPA), número e peso de nódulos secos e eficiência relativa (ER) de plantas agrupadas por propriedade.IAC-8, 50-54 dias após o plantio (continuação).

\begin{tabular}{|c|c|c|c|c|c|c|c|}
\hline \multirow{2}{*}{$\begin{array}{c}\mathrm{N}^{\circ} \mathrm{da} \\
\text { propriedade }\end{array}$} & \multirow[t]{2}{*}{ Sorogrupo } & \multirow{2}{*}{$\begin{array}{r}\mathrm{N}^{\mathrm{O}} \\
\mathrm{SMS}\end{array}$} & \multirow{2}{*}{$\begin{array}{c}\mathrm{N}^{\circ} \\
\text { TNPE }\end{array}$} & \multirow[t]{2}{*}{ MSPA } & \multicolumn{2}{|c|}{ Nódulo } & \multirow[t]{2}{*}{ ER } \\
\hline & & & & & Peso seco & Número & \\
\hline & & & & $\mathrm{g}$ & $\mathrm{mg}$ & & $\%$ \\
\hline \multirow{6}{*}{13} & IV & 867 & 2 & 4,72 & 730 & 116 & 89 \\
\hline & IV & 868 & 2 & 4,14 & 654 & 98 & 78 \\
\hline & VI & 869 & 2 & 4,07 & 470 & 104 & 77 \\
\hline & VI & 870 & 3 & 4,60 & 531 & 95 & 75 \\
\hline & VI & 871 & 3 & 3,52 & 493 & 72 & 58 \\
\hline & I & 872 & 3 & 5,58 & 550 & 164 & $91 *$ \\
\hline \multirow{7}{*}{14} & I & 875 & 3 & 4,80 & 544 & 185 & 79 \\
\hline & VI & 876 & 3 & 3,64 & 490 & 114 & 60 \\
\hline & VI & 878 & 4 & 1,69 & 73 & 47 & 77 \\
\hline & III & 880 & 4 & 1,92 & 321 & 48 & 87 \\
\hline & III & 882 & 4 & 2,17 & 354 & 61 & $99^{*}$ \\
\hline & III & 884 & 4 & 2,15 & 358 & 55 & $98^{*}$ \\
\hline & 1 & 885 & 4 & 2,06 & 299 & 82 & $94^{*}$ \\
\hline \multirow[t]{2}{*}{15} & I & 890 & 3 & 5,44 & 667 & 86 & 89 \\
\hline & I & 892 & 3 & 5,50 & 597 & 116 & 90 \\
\hline \multirow[t]{2}{*}{16} & IV & 893 & 3 & 3,67 & 538 & 122 & 60 \\
\hline & IV & 894 & 3 & 3,53 & 428 & 139 & 58 \\
\hline
\end{tabular}


5.1. Identificação de 91 estirpes isoladas de soja, por sorogrupo, número da Seção de Microbiologia- IAC (SMS), número do teste de nodulação preliminar de eficiência (TNPE), e dados obtidos em vasos de Leonard, em casa de vegetação, para matéria seca da parte aérea (MSPA), número e peso de nódulos secos e eficiência relativa (ER) de plantas agrupadas por propriedade.IAC-8, 50-54 dias após o plantio (continuação).

\begin{tabular}{|c|c|c|c|c|c|c|c|}
\hline \multirow{2}{*}{$\begin{array}{c}\mathrm{N}^{\mathrm{O}} \mathrm{da} \\
\text { propriedade }\end{array}$} & \multirow[t]{2}{*}{ Sorogrupo } & \multirow{2}{*}{$\begin{array}{r}\mathrm{N}^{\mathrm{O}} \\
\mathrm{SMS}\end{array}$} & \multirow{2}{*}{$\begin{array}{c}\text { No }^{\circ} \\
\text { TNPE }\end{array}$} & \multirow[t]{2}{*}{ MSPA } & \multicolumn{2}{|c|}{ Nódulo } & \multirow[t]{2}{*}{ ER } \\
\hline & & & & & Peso seco & Número & \\
\hline & & & & g & $\mathrm{mg}$ & & $\%$ \\
\hline & IX & 896 & 3 & 3,18 & 390 & 204 & 52 \\
\hline & I & 897 & 3 & 4,83 & 573 & 128 & 79 \\
\hline \multirow[t]{4}{*}{17} & I & 899 & 3 & 5,17 & 742 & 141 & 85 \\
\hline & IV & 901 & 3 & 3,07 & 181 & 80 & 50 \\
\hline & I & 902 & 3 & 3,06 & 444 & 164 & 50 \\
\hline & I & 904 & 3 & 3,42 & 420 & 90 & 56 \\
\hline \multirow[t]{4}{*}{18} & IX & 905 & 3 & 2,57 & 317 & 66 & 42 \\
\hline & IV & 906 & 3 & 2,99 & 293 & 104 & 49 \\
\hline & IV & 908 & 3 & 3,82 & 491 & 84 & 63 \\
\hline & I & 909 & 3 & 3,57 & 365 & 67 & 59 \\
\hline \multirow[t]{4}{*}{19} & I & 910 & 3 & 1,90 & 163 & 40 & 31 \\
\hline & VII & 913 & 3 & 3,45 & 393 & 110 & 57 \\
\hline & I & 914 & 3 & 5,03 & 603 & 204 & 82 \\
\hline & I & 915 & 3 & 2,63 & 317 & 132 & 43 \\
\hline \multirow[t]{3}{*}{20} & I & 916 & 3 & 5,16 & 630 & 142 & 85 \\
\hline & IV & 917 & 3 & 4,07 & 434 & 92 & 67 \\
\hline & $\mathrm{VI}$ & 919 & 3 & 5,56 & 765 & 153 & $91^{*}$ \\
\hline
\end{tabular}

* ER maior do que $90 \%$ 
5.2. Médias de número e peso seco de nódulos e matéria seca da parte aérea para os tratamentos padrão e controles de 4 testes de nodulação em soja em casa de vegetação. Plantas com 50-54 DAP. IAC-8.

\begin{tabular}{|c|c|c|c|}
\hline \multirow[t]{2}{*}{ tratamento $(1)$} & \multicolumn{2}{|c|}{ nódulos } & \multirow{2}{*}{$\begin{array}{c}\text { matéria seca } \\
\text { parte aérea } \\
\text { (g/planta) }\end{array}$} \\
\hline & $\mathbf{n} \%$ planta & $\mathrm{mg} /$ planta & \\
\hline \multicolumn{4}{|c|}{$1^{\circ} \mathrm{TNPE}(54 \mathrm{DAP})^{(2)}$} \\
\hline SEMIIA-587 & 70 & 444 & 6,36 \\
\hline SEMIA-5019 & 92 & 630 & 5,64 \\
\hline $\mathrm{C} / \mathbf{1}$ & - & - & 2,75 \\
\hline $\mathrm{C} / 2$ & - & - & 2,46 \\
\hline $\mathrm{C} / 3$ & - & - & 2,81 \\
\hline $\mathrm{C} / 4$ & - & - & 3,27 \\
\hline $\mathrm{C} / 5$ & - & - & 3,50 \\
\hline $\mathrm{C}+\mathrm{N} / 1$ & - & - & 7,21 \\
\hline \multirow[t]{2}{*}{$\mathrm{C}+\mathrm{N} / 2$} & - & - & 8,07 \\
\hline & \multicolumn{2}{|c|}{$2^{\circ} \mathrm{TNPE}(50 \mathrm{DAP})$} & \\
\hline SEMIA-587 & 86 & 420 & 5,26 \\
\hline SEMIA-5019 & 108 & 694 & 4,62 \\
\hline $\mathrm{C} / 1$ & - & - & 2,95 \\
\hline $\mathrm{C} / 2$ & $\cdot$ & - & 3,03 \\
\hline $\mathrm{C} / 3$ & - & - & 3,04 \\
\hline $\mathrm{C}+\mathrm{N} / \mathbf{1}$ & - & - & 7,57 \\
\hline \multirow{2}{*}{$\mathrm{C}+\mathrm{N} / 2$} & - & - & 7,46 \\
\hline & \multicolumn{2}{|c|}{$3^{\circ}$ TNPE (52 DAP) } & \\
\hline SEMIA-587/1 & 51 & 225 & 5,87 \\
\hline SEMIA-587/2 & 113 & 406 & 6,38 \\
\hline SMS-5019 & 104 & 615 & 5,08 \\
\hline $\mathrm{C} / 1$ & - & - & 2,72 \\
\hline $\mathrm{C} / 2$ & - & - & 1,22 \\
\hline $\mathrm{C} / 3$ & - & - & 2,49 \\
\hline $\mathrm{C} / 4$ & - & - & 3,40 \\
\hline $\mathrm{C} / 5$ & - & - & 2,17 \\
\hline $\mathrm{C}+\mathrm{N} / 1$ & - & - & 7,01 \\
\hline
\end{tabular}


5.2. Médias de número e peso seco de nódulos e matéria seca da parte aérea para os tratamentos padrão e controles de 4 testes de nodulação em soja em casa de vegetação. Plantas com 50-54 DAP. IAC-8 (continuação).

\begin{tabular}{lccc} 
& \multicolumn{2}{c}{ nódulos } & $\begin{array}{c}\text { matéria seca } \\
\text { parte aérea } \\
\text { tratamento }\end{array}$ \\
& $\mathbf{n}$ (1) $/$ planta $)$
\end{tabular}

$4^{\circ}$ TNPE (52 DAP)(3)

$\begin{array}{llll}\text { SEMIA-587/1 } & 47 & 293 & 2,28 \\ \text { SEMIA-587/2 } & 45 & 333 & 2,10 \\ \text { SEMIA-5019/1 } & 70 & 214 & 1,58 \\ \text { SEMIA-5019/2 } & 113 & 290 & 2,15 \\ \text { C/1 } & - & - & 1,71 \\ \text { C/2 } & - & - & 1,35 \\ \text { C+N/1 } & - & - & 2,25 \\ \text { C+N/2 } & - & - & 2,34\end{array}$

(1) Os tratamentos SEMIA-587 e SEMIA-5019 foram aqueles tomados como padrão. $\mathrm{C}$ e $\mathrm{C}+\mathrm{N}$ significam, controle e controle + nitrogènio, respectivamente. $O$ número após a barra ( () indica a repetição.

(2) TNPE = teste de nodulação e preliminar de eficiência; DAP = Dias após o plantio

(3) $\mathrm{O} 4^{\circ} \mathrm{TNPE}$ foi conduzido no inverno 
APÊNDICE 6- FIGURAS

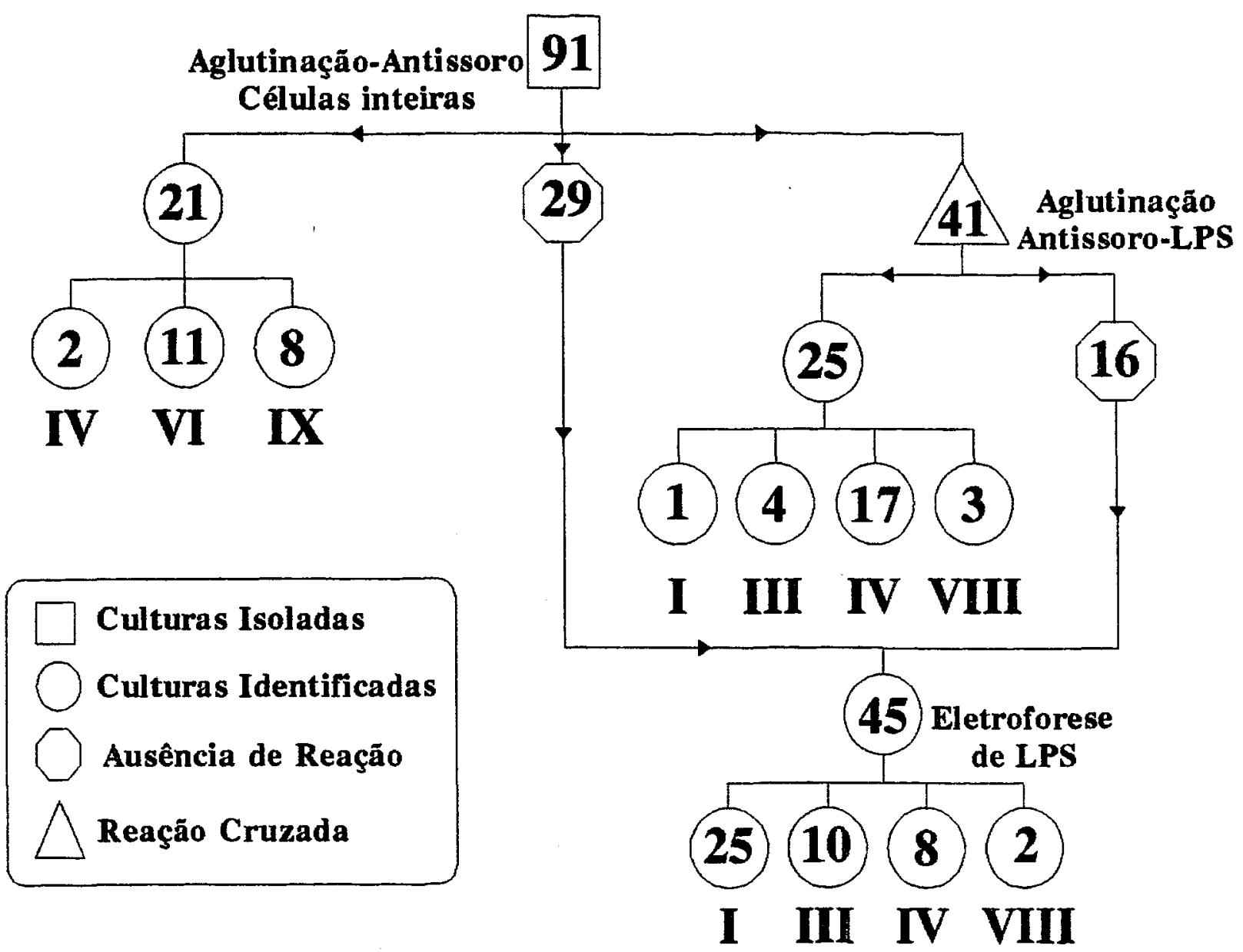

6.1. : Fluxograma da caracterização de 91 culturas puras isoladas de soja. 


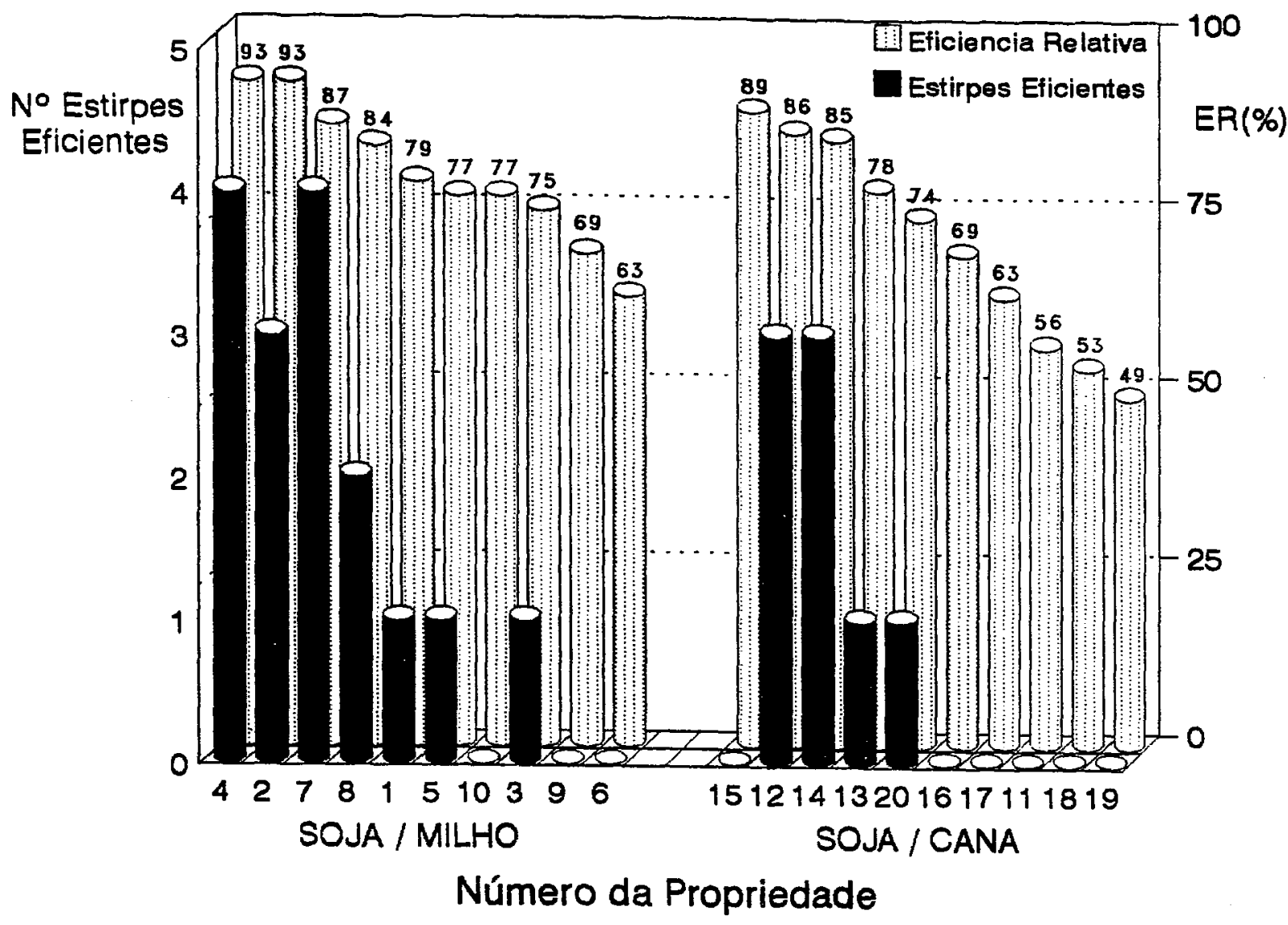

6.2. : Média da eficiência relativa dos isolados e número de estirpes eficientes, por propriedade, para os sistemas de cultivo de soja/milho e soja/cana 